THAIS DE CÁSSIA MARTINELLI GUERREIRO

\title{
ACIDENTALIDADE NO TRANSPORTE COLETIVO DA CIDADE DE SÃO CARLOS
}

Dissertação apresentada à Escola de Engenharia de São Carlos da Universidade de São Paulo, como parte dos requisitos para obtenção do título de Mestre em Engenharia Civil: Planejamento e Operação de Sistemas de Transportes.

Orientador: Prof. Titular Antonio Clóvis Pinto Ferraz

São Carlos

Julho

2008 
AUTORIZO A REPRODUÇÃO E DIVULGAÇÃO TOTAL OU PARCIAL DESTE TRABALHO, POR QUALQUER MEIO CONVENCIONAL OU ELETRÔNICO, PARA FINS DE ESTUDO E PESQUISA, DESDE QUE CITADA A FONTE.

Ficha catalográfica preparada pela Seçào de Tratamento da Informaçào do Serviço de Biblioteca - EESC/USP

G934a

Guerreiro, Thais de Cassia Martinelli

Acidentalidade no transporte coletivo da cidade de sao Carlos / Thais de Cassia Martinelli Guerreiro ; orientador Antonio Clóvis Pinto Ferraz. -- Såo Carlos, 2008 .

Dissertaçáo (Mestrado-Programa de Pós-Graduaça em Engenharia de Iransportes e Area de Concentração em Planejamento e operaçao de sistemas de Transportes) -Escola de Engenharia de sáo Carlos da Universidade de são Paulo, 2008 .

1. Segurança viária. 2. Acidente de transito. 3. Iransporte coletivo. 4. Sistema de informaçoes geograficas - SIG. 5. Açöes mitigadoras. I. Título. 
FOLHA DE JULGAMENTO

Candidata: Engenheira THAIS DE CASSIA MARTINELLI GUERREIRO

Dissertação defendida e julgada em 22/07/2008 perante a Comissão Julgadora:
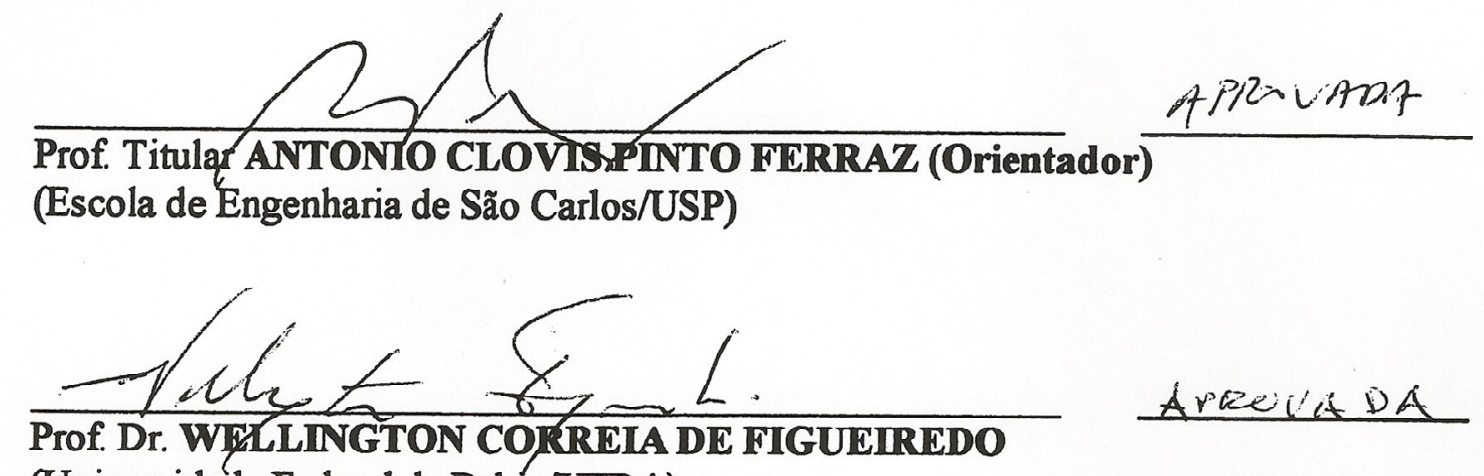

(Universidade Federal da Bahia/UFBA)

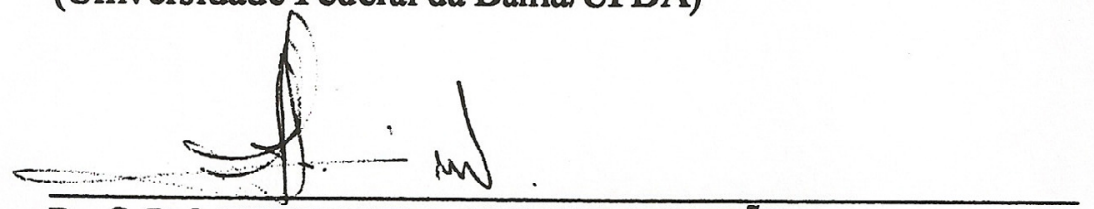

Prof. Dr". FERNANDA ANTONIO SIMŌES

(Universidade Estadual de Maringá/UEM)
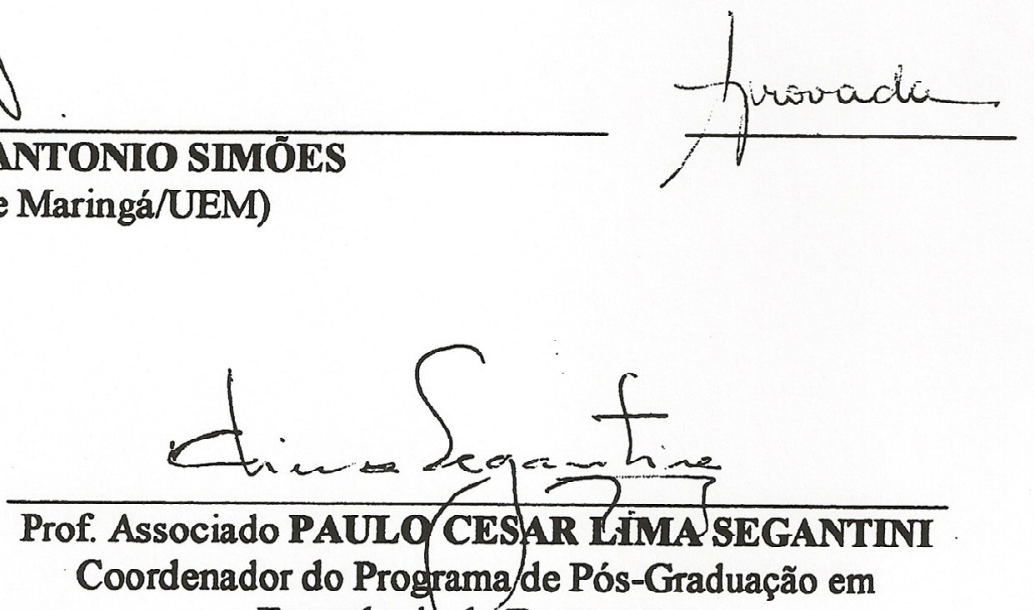

Engenharia de Transportes

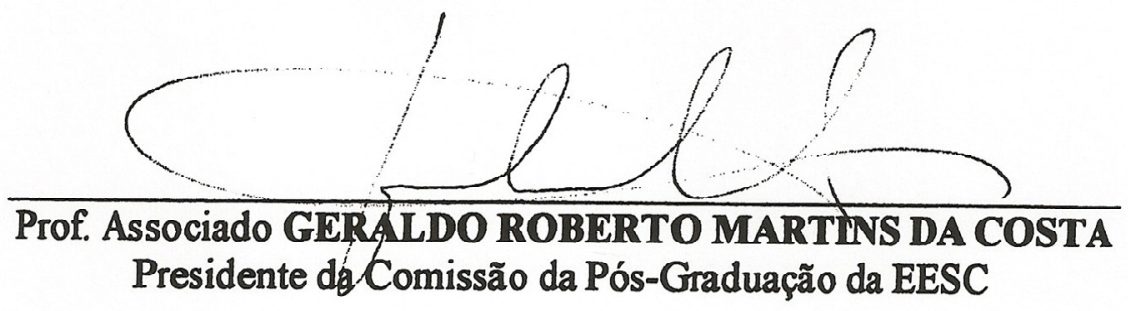


A Deus

Aos meus pais (José e Lourdes) e ao meu irmão (Pablo) por sempre terem me apoiado e encorajado a transpor os obstáculos presentes durante estes anos. Eles são a minha base e merecem, mais do que ninguém, este reconhecimento. 
Durante estes anos de trabalho foram muitas as pessoas que contribuíram para a conclusão deste trabalho. Este é o momento de agradecê-las e caso esqueça de alguém, peço desculpas por não conseguir lembrar de todas.

Agradeço à minha família, como dedicado anteriormente, pela confiança depositada em mim e auxílio em todos os momentos. Mesmo eu ausente em vários momentos, souberam me compreender e auxiliar.

A Pedro Gutemberg, meu namorado, por ter me apoiado nos momentos mais difíceis e sempre me mostrar que nunca devemos perder a esperança e que devemos ser fortes defronte todos os obstáculos que a vida nos apresenta. Muito obrigada!

Ao professor Antonio Clovis Pinto Ferraz (Coca), pela oportunidade de aprendizado e orientação para a realização deste trabalho.

Ao meu grande amigo Marcelo Massulo, por ter me ajudado muito neste trabalho e ter demonstrado que a distância, perante a amizade, não significa nada. Por todas as sugestões, questionamentos e paciência dedicados para a conclusão deste trabalho, meu muito obrigada. Valeu Massulo!

A todos da Secretaria Municipal de Transporte, Trânsito e Vias Públicas (SMTTVP) da cidade de São Carlos, por terem me acompanhado por todos estes anos, sempre me apoiarem e terem me proporcionado ensinamentos que ficarão guardados por toda a vida. Em 
especial, gostaria de agradecer às seguintes pessoas: Sandra Ichikawa, Alexandre Seixas e Marcelo Massulo, Ricardo Meirelles, Luis Eduardo Balau, Osni Frani da Silva, Cida Cris (Cidoca), Andréa Júlia, Marco Antonio, Leonardo Hotta, Daniel Gatti, Ilson Bogni, Ingridi Ienco, Rosângela Tramontelli, Dna. Guiomar, Dani, todos os estagiários que por lá passaram e muitas outras pessoas.

A todos os amigos do Departamento de Transportes, com os quais convivi durante algum tempo: Daniel, Bruno, Diogo, Fabíola, Cintia, Cida Cris, Vivian, Gustavo Manzato, Gustavo da Silveira, Camila, Thaís, Ana Beatriz, Márcia Lika, Marcão, Cira, Adriana, Andréa Júlia, André e Franciéli.

Aos funcionários do departamento: Heloisa, Beth, Magaly, Alexandre, Toco.

Ao professor Archimedes Azevedo Raia Jr., por me auxiliar em determinados momentos, durante todos esses anos.

Por fim, agradeço à Coordenadoria de Aperfeiçoamento de Pessoal de Nível Superior - CAPES pela bolsa de estudos concedida. 
"Dias inteiros de calmaria, noites de ardentia, dedos no leme e olhos no horizonte, descobri a alegria de transformar distâncias em tempo. Um tempo em que aprendi a entender as coisas do mar, a conversar com as grandes ondas e não discutir com o mau tempo. A transformar o medo em respeito, o respeito em confiança. Descobri como é bom chegar quando se tem paciência. E para se chegar, onde quer que seja, aprendi que não é preciso dominar a força, mas a razão. É preciso, antes de mais nada, querer."

Cem Dias entre Céu e Mar Amyr Klink 


\section{RESUMO}

GUERREIRO, T.C.M. Acidentalidade no transporte coletivo da cidade de São Carlos. 2008. 140 p. Dissertação (Mestrado) - Escola de Engenharia de São Carlos, Universidade de São Paulo, São Carlos, 2008.

Neste trabalho é apresentado o resultado de estudo sobre a acidentalidade no transporte coletivo da cidade de São Carlos - Brasil, utilizando como fontes de informações os registros contidos em Boletins de Ocorrência de acidentes da Polícia Militar e em Relatórios de Ocorrências, elaborados pela empresa operadora do Transporte Coletivo, ambos relativos aos anos de 2005 e 2006. O método utilizado compreende as seguintes etapas: i) Coleta dos Dados; ii) Processamento e Sistematização dos Dados; iii) Caracterização dos Acidentes; iv) Análise das Informações e Preparação de Diagnóstico; e, v) Elaboração de Ações Mitigadoras. O processamento e a sistematização dos dados foram realizados utilizando o Banco de Dados de Acidentes de Trânsito (BDAT) da cidade de São Carlos, ao passo que a caracterização foi realizada com foco na gravidade, tipologia, distribuição temporal e espacial dos acidentes. De forma a identificar os pontos, interseções, trechos e regiões críticas de ocorrência de acidentes de trânsito, utilizou-se um Sistema de Informação Geográfica - SIG, aplicado à área de Transportes. Como principais resultados obtiveram-se: $i$ ) maior ocorrência de acidentes que resultaram em Danos Materiais e de acidente do tipo Colisão Transversal; $i$ ) acidentes que resultaram em Vítimas Não Fatais ocorreram em maior número às sextas-feiras e os que resultaram em Vítimas Fatais aos finais de semana; iii) os acidentes encontraram-se espalhados por toda a cidade, com maior concentração no eixo norte-sul e próximo a pólos de serviços de saúde, dentre outros. As ações mitigadoras propostas foram de caráter geral, como por exemplo, melhoria da sinalização, realização de campanhas educativas, dentre outros; e de caráter específico, direcionada para o cruzamento que apresentou o maior número de acidente no período em estudo.

Palavras - chave: Segurança Viária, Acidente de Trânsito, Transporte Coletivo, Sistema de Informações Geográficas - SIG, Ações Mitigadoras. 
GUERREIRO, T.C.M. Accident occurrence in public transportation (buses) in the city of São Carlos. 2008. 140 p. Master's Dissertation - Department of Engineering, University of São Paulo, São Carlos, 2008.

This work presents the results of a study on accident occurrence in public transportation (buses) in the city of São Carlos - Brazil, using as information sources the records from Police Accident Reports from the local Police and Accident Reports performed by the company responsible for the Public Transportation (Buses), both for calendar years 2005 and 2006. The method applied comprises the following steps: $i$ ) Data collection; ii) Processing and Data Systematization; iii) Accident Characterization; iv) Information Analysis and Diagnosis Preparation; and v) Development of Mitigation Actions. Processing and Data Systematization were carried out using Traffic Accident Database (BDAT) from the city of São Carlos, whereas characterization was done focusing on severity, typology, temporal and spatial distribution of accidents. Geographic Information System (GIS) applied to Transportation field was used to identify intersections, road stretches and critical areas of traffic accident occurrence. The main results obtained were: i) most accidents resulted in Property Damage and Side Impacts ii) most Nonfatal accidents occurred in greater number on Fridays and Fatal ones on weekends ii) accidents took place throughout the city, with greater concentration on north-south routes and around heath care centers, among others. Proposed Mitigation Actions were of general nature, such as improvements to signals, educational campaigns, among others; and specific ones towards the intersection that presented the highest number of accidents during this study.

Key words: Road Safety, Traffic Accident, Public Transportation, Geographic Information System (GIS ), Mitigation Actions 


\section{LISTA DE FIGURAS}

Figura 2.1: Tipos de acidentes de trânsito.

Figura 2.2: Conjunto de fatores que podem influenciar a ocorrência de acidentes de trânsito.24

Figura 2.3: Probabilidade da existência de vítima fatal em função da velocidade e do tipo de acidente. 25

Figura 2.4: Layers de um SIG. 46

Figura 3.1: Estrutura do método do trabalho. 50

Figura 3.2: Tela de apresentação do BDAT 54

Figura 4.1: Localização da cidade de São Carlos. 61

Figura 4.2: Linhas do sistema de transporte coletivo da cidade de São Carlos. 63

Figura 4.3: Porcentagem de acidentes de trânsito envolvendo o transporte coletivo de acordo com a gravidade 65

Figura 4.4: Porcentagem de acidentes de trânsito envolvendo o transporte coletivo de acordo com o tipo. 66

Figura 4.5: Porcentagem de acidentes de trânsito envolvendo o transporte coletivo de acordo com o tipo considerando a gravidade. 68

Figura 4.6: Porcentagem de acidentes de trânsito envolvendo o transporte coletivo de acordo com o dia da semana. 69

Figura 4.7: Porcentagem de acidentes de trânsito envolvendo o transporte coletivo de acordo com o dia da semana considerando a gravidade. 71

Figura 4.8: Porcentagem de acidentes de trânsito envolvendo o transporte coletivo de acordo com o dia da semana considerando o tipo. 73 
Figura 4.9: Porcentagem de acidentes de trânsito envolvendo o transporte coletivo de acordo com os meses do ano.

Figura 4.10: Porcentagem de acidentes de trânsito envolvendo o transporte coletivo de acordo com o período do dia. 75

Figura 4.11: Porcentagem de acidentes de trânsito envolvendo o transporte coletivo de acordo com o período do dia considerando a gravidade. .76

Figura 4.12: Porcentagem de acidentes de trânsito envolvendo o transporte coletivo de acordo com o período do dia considerando os tipos de acidentes.

Figura 4.13: Porcentagem de acidentes de trânsito envolvendo o transporte coletivo de acordo com o intervalo horário. 79

Figura 4.14: Porcentagem de acidentes de trânsito envolvendo o transporte coletivo de acordo com as condições meteorológicas. 80

Figura 4.15: Porcentagem de acidentes de trânsito envolvendo o transporte coletivo de acordo com as condições meteorológicas considerando a gravidade.

Figura 4.16: Porcentagem de acidentes de trânsito envolvendo o transporte coletivo de acordo com as condições meteorológicas considerando os tipos de acidentes. 82

Figura 4.17: Mapa referente à distribuição espacial dos acidentes de trânsito no biênio 2005 2006.

Figura 4.18: Mapa referente à distribuição espacial dos acidentes de trânsito com vítimas no biênio 2005 - 2006.

Figura 4.19: Mapa referente à distribuição espacial dos acidentes de trânsito com vítimas fatais no biênio 2005 - 2006.

Figura 4.20: Porcentagem de acidentes de trânsito envolvendo o transporte coletivo de acordo com as condições meteorológicas considerando os tipos de acidentes. 
Figura 4.21: Mapa referente à distribuição espacial dos acidentes de trânsito ocorridos ao longo das vias no biênio 2005 - 2006

Figura 4.22: Mapa referente à distribuição espacial dos acidentes de trânsito ocorridos em interseções no biênio 2005 - 2006. 88

Figura 4.23: Mapa temático referente às vias de transporte coletivo com número absoluto mínimo de 3 acidentes 90

Figura 4.24: Mapa temático referente aos locais (interseções) com número absoluto mínimo de 2 acidentes.

Figura 5.1: Primeira via mais crítica - Avenida São Carlos.

Figura 5.2: Segunda via mais crítica - Rua Dona Alexandrina 104

Figura 5.3: Primeira interseção mais crítica - Rua Serafim Vieira de Almeida x Rua Maestro João Seppe. 108

Figura 5.4: Segunda interseção crítica - Rua Sebastião Sampaio Osório x Avenida Bruno Ruggiero Filho 110

Figura 6.1: Pontos de conflito existentes na interseção Rua Maestro João Seppe x Rua Serafim Vieira de Almeida. 115

Figura 6.2: Croqui da interseção mais crítica - Rua Maestro João Seppe x Rua Serafim Vieira de Almeida 116

Figura 6.3: Interseção mais crítica - Rua Serafim Vieira de Almeida x Rua Maestro João Seppe - Vista da Rua Serafim Vieira de Almeida (sentido Santa Casa $\rightarrow$ Shopping Iguatemi)

Figura 6.4: I Interseção mais crítica - Rua Serafim Vieira de Almeida x Rua Maestro João Seppe - Vista da Rua Serafim Vieira de Almeida (sentido Shopping Iguatemi $\rightarrow$ Santa Casa)

Figura 6.5: Interseção Rua Serafim Vieira de Almeida x Rua Maestro João Seppe - Vista da Rua Maestro João Seppe (sentido Rua Miguel Petroni $\rightarrow$ Rua XV de Novembro). 118 
Figura 6.6: Interseção Rua Serafim Vieira de Almeida x Rua Maestro João Seppe - Vista da Rua Maestro João Seppe (sentido Rua XV de Novembro $\rightarrow$ Rua Miguel Petroni).....

Figura 6.7: Pontos de conflito existentes para a nova configuração da interseção Rua Maestro João Seppe x Rua Serafim Vieira de Almeida.

Figura 6.8: Croqui proposto para a interseção Rua Maestro João Seppe x Rua Serafim Vieira de Almeida.

Figura A1: Relatório de Ocorrência de Acidentes de Trânsito (frente) 137

Figura A2: Relatório de Ocorrência de Acidentes de Trânsito (verso) 138

Figura A3: Tela de consulta aos anos no BDAT 139

Figura A4: Formulário de preenchimento do BDAT para a inserção dos dados de acidentes de trânsito 139

Figura A.5: Tela de consulta às características dos acidentes do BDAT 140

Figura A.6: Banco de atributos gráficos e não gráficos dos acidentes de trânsito para o biênio $2005-2006$ 140 


\section{LISTA DE TABELAS}

Tabela 1.1: Taxas de mortalidade no trânsito em alguns países.

Tabela 2.1: Custos totais dos acidentes nas aglomerações por grupo de componentes de custo em 2001 (Custo em R \$ de abril/2003)

Tabela 2.2: Custos totais dos acidentes associados aos diversos tipos de veículos e a participação percentual na frota (Custo em $R$ \$ de abril/2003).

Tabela 2.3: Custos médios dos acidentes nas aglomerações urbanas brasileiras, por tipo, em 2001 (Custo em R\$ de abril de 2003).

Tabela 2.4: Escala AIS dos acidentes de trânsito

Tabela 2.5: Coeficientes de aderência típicos para pneus. 20

Tabela 2. 6: Condições do tempo e quantidade de acidentes.

Tabela 2.7: Taxa de mortalidade por modo de transporte por 100 milhões de pass.km nos países da União Européia

Tabela 2.8: Taxa de mortalidade por modo de transporte por 100 milhões de pass.horas de viagem nos países da União Européia. 28

Tabela 4.1: Número de acidentes de trânsito envolvendo o transporte coletivo de acordo com a gravidade. 64

Tabela 4.2: Número de acidentes de trânsito envolvendo o transporte coletivo de acordo com o tipo.

Tabela 4.3: Número de acidentes de trânsito envolvendo o transporte coletivo de acordo com o tipo considerando a gravidade. 
Tabela 4.4: Número de acidentes de trânsito envolvendo o transporte coletivo de acordo com o dia da semana.

Tabela 4.5: Número de acidentes de trânsito envolvendo o transporte coletivo de acordo com o dia da semana considerando a gravidade 70

Tabela 4.6: Número de acidentes de trânsito envolvendo o transporte coletivo de acordo com o dia da semana considerando o tipo. 72

Tabela 4.7: Número de acidentes de trânsito envolvendo o transporte coletivo de acordo com os meses do ano. 73

Tabela 4.8: Número de acidentes de trânsito envolvendo o transporte coletivo de acordo com o período do dia. 74

Tabela 4.9: Número de acidentes de trânsito envolvendo o transporte coletivo de acordo com o período do dia considerando a gravidade. 75

Tabela 4.10: Número de acidentes de trânsito envolvendo o transporte coletivo de acordo com o período do dia considerando os tipos de acidentes. .76

Tabela 4.11: Número de acidentes de trânsito envolvendo o transporte coletivo de acordo_com o intervalo horário.

Tabela 4.12: Número de acidentes de trânsito envolvendo o transporte coletivo de acordo_com condições meteorológicas.

Tabela 4.13: Número de acidentes de trânsito envolvendo o transporte coletivo de acordo com as condições meteorológicas considerando a gravidade.

Tabela 4.14: Número de acidentes de trânsito envolvendo o transporte coletivo de acordo com as condições meteorológicas considerando os tipos de acidentes. 
Tabela 4.15: Número de acidentes de trânsito envolvendo o transporte coletivo de acordo com o local de ocorrência 86

Tabela 4.16: Vias com número absoluto mínimo de 3 acidentes. 89

Tabela 4.17: Locais (interseções) com número absoluto mínimo de 2 acidentes... 91 


\section{LISTA DE SIGLAS}

ABDAT

ABNT

ACT

AIS

ANTP

ASV

BDAT

BO

CET

CONTRAN

CTB

DENATRAN

ECMT

EESC

EMDEC

ETSC

FHWA

GMRL

IBGE

ICTCT

IPEA

OMS

PGT

PMSC
Análise do Banco de Dados de Acidentes de Trânsito

Associação Brasileira de Normas Técnicas

Análise de Conflitos de Tráfego

Abbreviated Injury Scale

Associação Nacional de Transportes Públicos

Auditoria de Segurança Viária

Banco de Dados de Acidentes de Trânsito

Boletim de Ocorrência

Companhia de Engenharia de Tráfego

Conselho Nacional de Trânsito

Código de Trânsito Brasileiro

Departamento Nacional de Trânsito

European Conference of Ministers of Transport

Escola de Engenharia de São Carlos

Empresa Municipal de Desenvolvimento de Campinas

European Transport Safety Council

Federal Highway Administration

General Motors Research Laboratory

Instituto Brasileiro de Geografia e Estatística

Institute for Cooperation on Traffic Conflict Techniques

Instituto de Pesquisa Econômica Aplicada

Organização Mundial da Saúde

Pólo Gerador de Tráfego

Prefeitura Municipal de São Carlos 
RO

SIG

SIG-T

SMTTVP

STT

TRANSERP

TRB

VMA
Registro de Ocorrência

Sistema de Informações Geográficas

Sistema de Informações Geográficas para Transportes

Secretaria Municipal de Transporte, Trânsito e Vias

Públicas

Departamento de Transportes

Empresa de Trânsito e Transporte Urbano de Ribeirão Preto

Transportation Research Board

Volumes Médios Anuais de Tráfego 


\section{SUMÁRIO}

1 INTRODUÇÃ

1.1 CONSIDERAÇÕES INICIAIS.............................................................................. 1

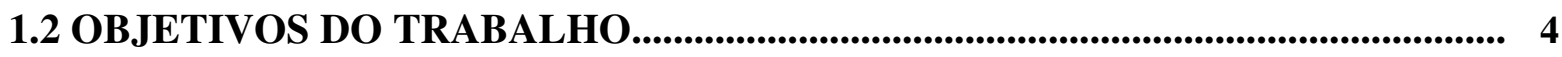

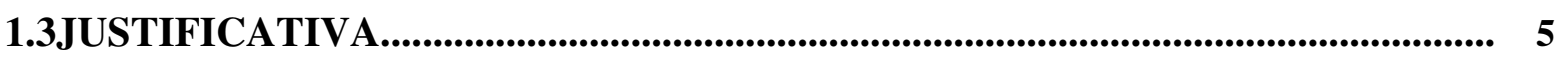

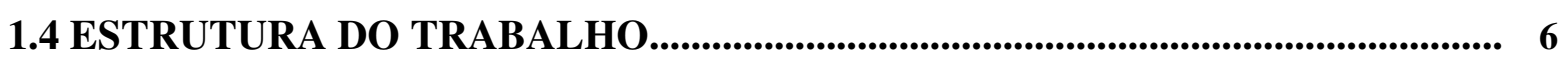

2 REVISÃO BIBLIOGRÁFICA.................................................................................. 8

2.1 SEGURANÇA DO TRÂNSITO........................................................................................ 8

2.1.1 Custos dos Acidentes de Trânsito........................................................................ 8

2.1.2 Definição, Classificação e Tipos de Acidentes de Trânsito........................................ 11

2.1.3 Principais Fatores de Ocorrência dos Acidentes de Trânsito..................................... 15

2.1.4 Técnicas Utilizadas no Estudo da Segurança do Trânsito.......................................... 28

2.1.5 Coleta e Tipos de Dados sobre os Acidentes de Trânsito.......................................... 32

2.1.6 Localização e Análise dos Acidentes de Trânsito...................................................... 34

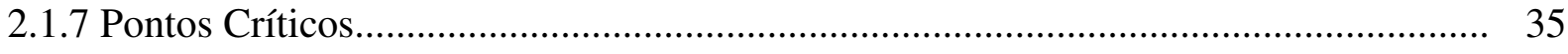

2.1.8 A Importância das Estatísticas......................................................................... 36

2.2 SEGURANÇA NO TRANSPORTE COLETIVO............................................................ 37

2.3 SISTEMA DE INFORMAÇÕES GEOGRÁFICAS (SIG)......................................... 44 


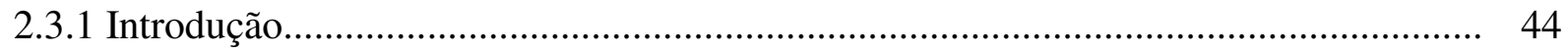

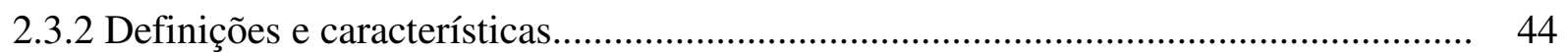

2.3.3 Sistema de Informações Geográficas para Transportes (SIG-T) .............................. 47

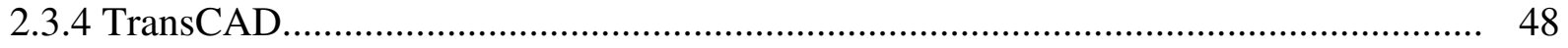

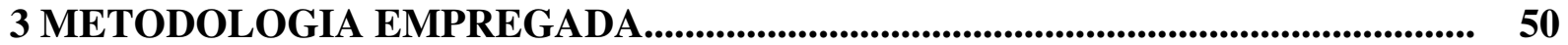

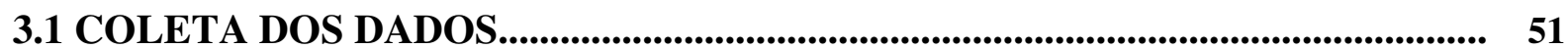

3.2 PROCESSAMENTO E SISTEMATIZAÇÃO DOS DADOS................................ 53

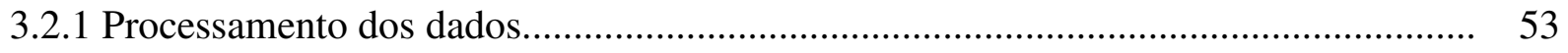

3.2.2 Análise de consistência dos dados......................................................................... 55

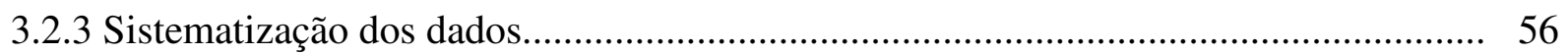

3.3 CARACTERIZAÇÃO DOS ACIDENTES............................................................... 57

3.4 ANÁLISE DAS INFORMAÇÕES E PREPARAÇÃO DE DIAGNÓSTICO.......... 58

3.5 PROPOSIÇÃO DE AÇÕES MITIGADORAS......................................................... 59

4 CARACTERIZAÇÃO DOS ACIDENTES...................................................................... 61

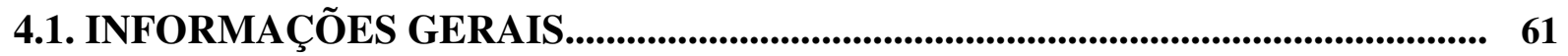

4.2. CARACTERÍSTICAS DOS ACIDENTES........................................................... 64

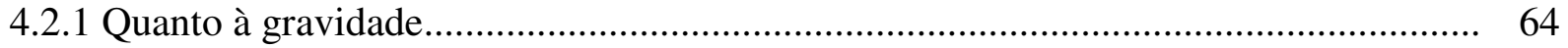

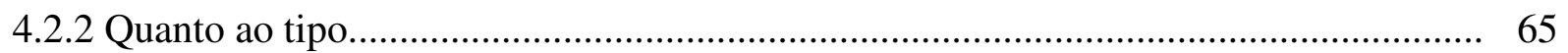

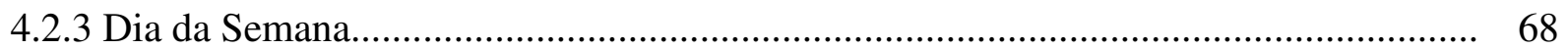

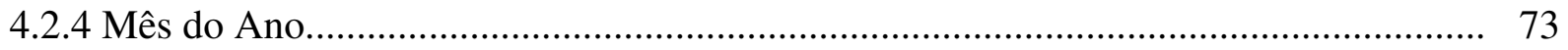


8 REFERÊNCIAS BIBLIOGRÁFICAS............................................ 128

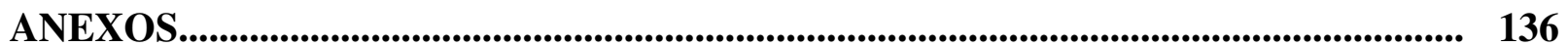




\section{1}

INTRODUCÃO

\subsection{CONSIDERAÇÕES INICIAIS}

Os acidentes de trânsito constituem uma verdadeira catástrofe para a humanidade. De acordo com a Organização Mundial da Saúde - OMS (2004), os acidentes de trânsito provocam, anualmente, cerca de 1,2 milhão de mortes no mundo (mais de 3.250 mortes por dia) e entre 20 e 50 milhões de feridos - muitos ficando com lesões permanentes que os tornam deficientes físicos ou mentais.

Ainda de acordo com a OMS (2004), estima-se que o número de mortes proveniente de acidentes de trânsito crescerá cerca de $65 \%$ até o ano 2020, considerando um aumento de $83 \%$ nos países não desenvolvidos e uma redução de $27 \%$ nas nações desenvolvidas, uma vez que estes últimos têm conseguido reduzir os acidentes e as mortes no trânsito através de programas para a redução destes acidentes.

No Brasil, segundo Ferraz e Raia Jr. (2005), estima-se que anualmente o número de mortos decorrentes de acidentes de trânsito seja cerca de 32 mil, podendo chegar a 50 mil, caso seja realizado o acompanhamento do estado de saúde das vítimas após os acidentes. Com relação ao número anual de feridos em acidentes de trânsito, este é superior a 400 mil, com cerca de 140 mil pessoas ficando com lesões físicas e mentais, permanentes.

Considerando o valor conservador de 32 mil óbitos, verifica-se que a relação entre o número de mortos no trânsito e a frota de veículos no Brasil é muito maior que as observadas nos países desenvolvidos: 7,6 vezes maior que na Suíça e Suécia, 6,9 vezes maior que no 
Japão e Reino Unido. Considerando o valor estimado de 50 mil, esses valores ficam ainda maiores: 11,9 vezes maior na Suíça, 11,8 na Suécia, 10,7 no Japão e no Reino Unido (FERRAZ e RAIA Jr. 2005). Na Tabela 1.1 tem-se a taxa de mortalidade no trânsito em alguns países.

Tabela 1.1: Taxas de mortalidade no trânsito em alguns países.

\begin{tabular}{|c|c|c|c|c|c|}
\hline País & $\begin{array}{c}\text { Veículos } \\
\text { por } 100 \\
\text { habitantes }\end{array}$ & $\begin{array}{c}\text { Taxa de } \\
\text { mortes } \\
\text { por } \\
100.000 \\
\text { habitantes }\end{array}$ & $\begin{array}{c}\text { Taxa de } \\
\text { mortes por } \\
100.000 \\
\text { veículos }\end{array}$ & $\begin{array}{c}\text { Relação } \\
\text { mortos/veículo } \\
\text { no Brasil e nos } \\
\text { outros países }^{\text {b }}\end{array}$ & $\begin{array}{c}\text { Relaçãa } \\
\text { mortos/veículo } \\
\text { no Brasil e nos } \\
\text { outros países }\end{array}$ \\
\hline Suíça & 66,2 & 7,1 & 10,7 & 7,6 & 11,9 \\
\hline Suécia & 55,4 & 6 & 10,8 & 7,6 & 11,8 \\
\hline Japão & 63,1 & 7,5 & 11,9 & 6,9 & 10,7 \\
\hline $\begin{array}{l}\text { Reino } \\
\text { Unido }\end{array}$ & 51,3 & 6,1 & 11,9 & 6,9 & 10,7 \\
\hline Alemanha & 64,7 & 8,3 & 12,8 & 6,4 & 10 \\
\hline Canadá & 59,3 & 9,3 & 15,7 & 5,2 & 8,1 \\
\hline E.U.A & 78,3 & 14,9 & 19 & 4,3 & 6,7 \\
\hline França & 59,6 & 12,9 & 21,6 & 3,8 & 5,9 \\
\hline Polônia & 40,6 & 15,3 & 37,7 & 2,2 & 3,4 \\
\hline Grécia & 48 & 19,3 & 40,2 & 2 & 3,2 \\
\hline Hungria & 29,2 & 14 & 47,9 & 1,7 & 2,7 \\
\hline Coréia & 30,7 & 14,9 & 48,5 & 1,7 & 2,6 \\
\hline Brasil $^{\mathrm{a}}$ & 21,8 & $17,8^{b} / 27,8^{c}$ & $81,7^{\mathrm{b}} / 127,7^{\mathrm{c}}$ & 1 & 1 \\
\hline Turquia & 5,6 & 14,3 & 255,4 & 0,3 & 0,5 \\
\hline
\end{tabular}

Fonte: Ferraz e Raia Jr., 2005.

${ }^{\text {a }}$ Valores estimados com base nas estatísticas referentes ao ano de 2004.

${ }^{\mathrm{b}}$ Valores considerando 32 mil mortes anuais.

${ }^{\mathrm{c}}$ Valores considerando 50 mil mortes anuais.

Um aspecto extremamente negativo dos acidentes de trânsito é o impacto que têm sobre a economia dos países. Segundo dados da OMS (2004), o custo monetário anual dos ferimentos e mortes no trânsito no mundo é estimado em 518 bilhões de dólares. 
No Brasil, de acordo com Ferraz e Raia Jr. (2005), o custo dos acidentes de trânsito é da ordem de 30 bilhões de reais por ano. Nesse montante estão incluídos os seguintes custos: despesa médico-hospitalar, tratamento e reabilitação das vítimas, perdas materiais (veículos, carga e objetos físicos, como postes, sinais de trânsito, muros, etc.), remoção dos veículos acidentados, resgate das vítimas, limpeza e reparo dos danos causados à via e à sinalização de trânsito, perdas de dia de trabalho, pensões e aposentadorias precoces, custos policiais e judiciários, funerais, etc.

De acordo com estudo realizado pelo Instituto de Pesquisa Econômica Aplicada IPEA (2003), somente em aglomerações urbanas no Brasil no ano 2001, a estimativa dos custos associados aos acidentes de trânsito ultrapassou o valor de 5 bilhões de reais. Ainda de acordo com o mesmo estudo, considerando dados de duas empresas de ônibus na aglomeração urbana da cidade de São Paulo, verificou-se no ano 2001, uma frota de 785 ônibus e um número total de 1.754 acidentes, sendo 1.622 acidentes sem vítimas e 132 com vítimas, resultando em alguns valores importantes: 2,23 acidentes/ônibus.ano, 2,07 acidentes sem vítimas/ônibus.ano e 0,17 acidentes com vítimas/ônibus.ano.

A cidade de São Carlos, objeto de estudo deste trabalho, considerando os dados referentes aos anos de 2005 e 2006, apresentou uma média de 170 acidentes de trânsito envolvendo o transporte coletivo por ônibus, sendo 135 acidentes sem vítimas e 35 com vítimas, para uma frota média de 97 veículos. Considerando esses dados, alguns valores importantes podem ser evidenciados: 1,75 acidentes/ônibus.ano, 1,39 acidentes sem vítimas/ônibus.ano e 0,36 acidentes com vítimas/ônibus.ano.

Comparando-se os valores apresentados em estudo desenvolvido por IPEA (2003) envolvendo ônibus na ocorrência de acidentes de trânsito, São Carlos apresentou índices 
menores relativos ao total de acidentes $(21,52 \%$ menor $)$ e de acidentes sem vítimas $(32,85 \%$ menor), sendo que o relativo ao acidentes com vítimas apresentou aumento de $111,76 \%$.

Muitos trabalhos relacionados à segurança viária que visam investigar as principais características dos acidentes de trânsito e suas principais causas de ocorrência, bem como ações para mitigar a ocorrência desses acidentes, já foram desenvolvidos em âmbito nacional. Dentre eles, citam-se os desenvolvidos por Setti (1985), Simões (2001), Mantovani (2003), Meirelles (2003), Queiroz (2003), Teixeira (2003), Chueire (2004), Mon - Ma (2005), Santos (2006).

\subsection{OBJETIVOS DO TRABALHO}

O propósito deste trabalho é analisar a acidentalidade no transporte coletivo da cidade de São Carlos.

Mais especificamente, os objetivos são:

- Proceder à caracterização dos acidentes no tocante à gravidade, tipologia, distribuição temporal e espacial, etc.;

- Elaborar diagnóstico da situação, identificando os tipos, os horários, os dias da semana e os locais com maior freqüência de ocorrência de acidentes de trânsito, bem como suas causas, etc; e,

- Propor um elenco de ações mitigadoras visando à melhoria da segurança no transporte coletivo da cidade de São Carlos. 


\subsection{JUSTIFICATIVA}

Segundo a Associação Nacional de Transportes Públicos - ANTP (2008), considerando dados relativos ao ano de 2003 referente a 437 municípios brasileiros com população igual ou superior a 60.000 habitantes, de um total de 53.456 viagens, o transporte coletivo (incluindo ônibus municipal, ônibus metropolitano e trilhos) foi responsável por 15.574 viagens $(29,13 \%$ do total). Considerando somente o transporte coletivo, o ônibus municipal foi responsável por 11.480 viagens $(73,71 \%$ do total), o ônibus metropolitano por 2.445 viagens $(15,70 \%$ do total) e trilhos por 1.649 viagens $(10,59 \%$ do total), o que evidencia o papel fundamental do transporte coletivo por ônibus nos deslocamentos urbanos. Em virtude da indisponibilidade do número de viagens atribuídas ao transporte coletivo por ônibus, estima-se que na cidade de São Carlos, $30,00 \%$ da população realize seus deslocamentos utilizando este modo de transporte.

Segundo Ferraz e Torres (2004), a elevada demanda por transporte coletivo por ônibus nos deslocamentos urbanos pode ser justificada pelas seguintes razões: $i$ ) apresenta-se com um modo de transporte motorizado com menor custo unitário; ii) constitui uma alternativa de transporte em substituição ao automóvel; iii) auxilia na redução de congestionamentos, da poluição e do grande uso de energia; iv) apresenta grande capacidade de transporte de passageiros; v) propicia, quase sempre, total segurança aos passageiros, entre outras.

Diante da grande importância do transporte coletivo por ônibus na locomoção urbana em várias cidades brasileiras como também na cidade de São Carlos, além de sua elevada capacidade de transporte (em determinados horários a lotação pode chegar a 80 pessoas), é necessário propiciar um panorama da segurança viária no transporte público, evidenciando os tipos de acidentes mais freqüentes, seus locais de ocorrência, bem como suas principais causas de ocorrências, dentre outros fatores. 
A partir deste panorama será possível propor ações mitigadoras para a redução desses acidentes, contribuindo para a preservação e a integridade das pessoas, e, conseqüentemente, um trânsito mais seguro.

\subsection{ESTRUTURA DO TRABALHO}

Esta dissertação está estruturada em 8 capítulos.

No Capítulo 01 é apresentada uma introdução sobre o tema, abordados assuntos como o panorama geral da situação mundial e brasileira com relação aos acidentes de trânsito, os objetivos do trabalho, justificativa e a estrutura da dissertação.

No Capítulo 02 tem-se a revisão da literatura existente relacionada aos temas da pesquisa, evidenciando os tipos de gravidade possíveis em um acidente de trânsito, os tipos de acidentes existentes, principais técnicas para o estudo dos acidentes, acidentes de trânsito envolvendo os ônibus de transporte coletivo, dentre outros.

A metodologia empregada para o estudo da acidentalidade envolvendo o transporte coletivo por ônibus é relatada no Capítulo 03.

No Capítulo 04, através do emprego da metodologia apresentada, é realizada uma caracterização dos acidentes, levantando suas principais características, bem como os locais de ocorrência visualizados com o auxílio de mapas temáticos.

Um diagnóstico da acidentalidade é realizado no Capítulo 05, comentando as principais características levantadas no Capítulo 04. 
No Capítulo 06 tem-se a proposição de ações mitigadoras com o objetivo de reduzir a ocorrência de acidentes de trânsito envolvendo os ônibus de transporte coletivo. Estas ações podem ser de dois tipos: $i$ ) caráter geral (âmbito do Poder Público e da empresa operadora); e, ii) caráter específico, voltada para a interseção mais crítica de ocorrência de acidentes.

As considerações gerais a respeito deste trabalho são apresentadas no Capítulo 07.

Por fim, as referências bibliográficas utilizadas para a elaboração deste trabalho são apresentadas no Capítulo 08. Em complementação às informações apresentadas, é apresentado um anexo contendo as demais informações relevantes. 


\section{2}

\section{REVISÃO BIBLIOGRÁFICA}

\subsection{SEGURANÇA DO TRÂNSITO}

\subsubsection{Custos dos Acidentes de Trânsito}

Os acidentes de trânsito geram muitos prejuízos, dentre eles podem-se citar prejuízos: i) humanos, representados através das mortes, casos de invalidez, seqüelas, dentre outros; ii) econômicos, como custos associados aos danos materiais e despesas médicas com as vítimas, dentre outros; iii) ambientais, como no caso de veículos carregados com cargas tóxicas, as quais entram em contato com o meio ambiente de maneira indevida; e, iv) sociais onde se pode citar a perda de entes queridos que podem levar à desestruturação familiar, repercutindo socialmente em diversos níveis.

De acordo com Cardoso (1999), os custos dos acidentes de trânsito são definidos primeiramente, a partir da identificação de todos os elementos que os compõem para posteriormente, através de critérios metodológicos, serem realizadas as quantificações necessárias.

Para IPEA (2003), foram considerados os seguintes custos associados aos acidentes de trânsito: $i$ ) custo do atendimento médico-hospitalar e reabilitação; ii) custo do atendimento policial e de agentes de trânsito; iii) custo de congestionamento; iv) custo dos danos aos equipamentos urbanos; v) custo dos danos à propriedade de terceiros; vi) custo dos danos à sinalização de trânsito; vii) custo dos danos aos veículos; viii) custo do impacto familiar; $i x$ ) custo de outro meio de transporte; $x$ ) custo da perda de produção; $x i$ ) custo previdenciário; $x i i$ ) 
custo de processos judiciais; xiii) custo de remoção de veículos; e, xiv) custo do resgate de vítimas. Na Tabela 2.1, têm-se os custos totais dos acidentes nas aglomerações por grupo de componentes de custo para o ano 2001.

Tabela 2.1: Custos totais dos acidentes nas aglomerações por grupo de componentes de custo em 2001 (Custo em R \$ de abril/2003).

\begin{tabular}{lcc}
\hline \multicolumn{1}{c}{ Componente de custo } & \multicolumn{2}{c}{ Custo } \\
\cline { 2 - 3 } & R\$ milhões & \% \\
\hline Perda de produção & 1.537 & 42,8 \\
$\begin{array}{l}\text { Danos à propriedade - veículos, equipamento urbano, } \\
\text { sinalização de trânsito, propriedade de terceiros, } \\
\text { urbanas }\end{array}$ & 1.076 & 30 \\
$\begin{array}{l}\text { Custos médico-hospitalares - resgate, tratamento } \\
\text { médico e reabilitação }\end{array}$ & 571 & 15,9 \\
$\begin{array}{l}\text { Outros custos - judiciais, congestionamento, } \\
\text { previdenciário, remoção de veículos, outros meios de } \\
\text { transporte, atendimento policial,agente de trânsito, }\end{array}$ & 406 & 11,3 \\
impacto familiar & & \\
\hline Total & & $\mathbf{1 0 0}$ \\
\hline
\end{tabular}

Fonte: IPEA (2003).

Conforme a Tabela 2.1, o custo da perda de produção responde por $42,8 \%$ dos custos totais dos acidentes de trânsito e é muito influenciado pelos acidentes com vítimas. Os custos médico-hospitalares representam cerca de $16,0 \%$ dos custos totais dos acidentes de trânsito, estando presente somente nos acidentes com vítimas.

Com relação aos custos de acordo com a categoria veicular, IPEA (2003) ressaltou a necessidade de haver um enfoque especial para com os acidentes envolvendo ônibus e caminhões, em virtude da maior exposição ao risco dos mesmos, além dos custos envolvidos. $\mathrm{Na}$ Tabela 2.2, têm-se os custos totais associados aos diversos tipos de veículos e a participação percentual dos mesmos na frota total. 
Tabela 2.2: Custos totais dos acidentes associados aos diversos tipos de veículos e a participação percentual na frota (Custo em $\mathrm{R} \$$ de abril/2003).

\begin{tabular}{lccc}
\hline \multirow{2}{*}{ Tipo de veículo } & \multicolumn{2}{c}{ Custo } & Frota de veículos \\
\cline { 2 - 3 } & $\mathbf{R} \$$ & $\mathbf{\%}$ & $\mathbf{\%}$ \\
\hline Automóveis & 1.993 .682 .470 & 56 & 74 \\
Motocicletas & 684.955 .145 & 19 & 11 \\
Ônibus urbanos & $\mathbf{4 6 0 . 1 1 7 . 3 4 8}$ & $\mathbf{1 3}$ & $\mathbf{1}$ \\
Caminhões & 404.114 .440 & 11 & 4 \\
Utilitários leves & 47.852 .883 & 1 & 10 \\
\hline Total & $\mathbf{3 . 5 9 0 . 7 2 2 . 2 8 7}$ & $\mathbf{1 0 0}$ & $\mathbf{1 0 0}$ \\
\hline
\end{tabular}

Fonte: IPEA (2003)

De acordo com a Tabela 2.2, os ônibus urbanos representam $1 \%$ da frota em aglomerações urbanas, entretanto representam $13 \%$ dos custos totais dos acidentes ocorridos nessas aglomerações. Isto mostra que os ônibus urbanos devido às suas maiores dimensões, capacidade máxima de transporte, maior espaço ocupado na via, dentre outros fatores, embora apresentem uma frota cerca de $0,014 \%$ menor do valor da frota de automóveis, apresentam custos totais cerca de $0,23 \%$ menor dos custos totais envolvendo automóveis.

No tocante à gravidade dos acidentes, na pesquisa realizada por IPEA (2003), a estimativa dos custos médios dos acidentes de trânsito considerou somente os acidentes ocorridos nas aglomerações urbanas, conforme Tabela 2.3.

Tabela 2.3: Custos médios dos acidentes nas aglomerações urbanas brasileiras, por tipo, em 2001 (Custo em R \$ de abril de 2003).

\begin{tabular}{lcccc}
\hline $\begin{array}{c}\text { Tipo de } \\
\text { acidente }\end{array}$ & $\begin{array}{c}\text { Veículos } \\
\text { envolvidos por } \\
\text { acidente }\end{array}$ & $\begin{array}{c}\text { Custo por } \\
\text { veículo } \\
\text { acidentado } \\
(\mathbf{R} \$)\end{array}$ & $\begin{array}{c}\text { Custo por } \\
\text { acidente (R\$) }\end{array}$ & $\begin{array}{c}\text { Custo por } \\
\text { vítima (R\$) }\end{array}$ \\
\hline Com mortos & 1,11 & 130.489 & 144.478 & 109.709 \\
Com feridos & 1,52 & 11.458 & 17.460 & 14.233 \\
Sem vítima & 2,01 & 1.625 & 3.262 & - \\
Global & 1,92 & 4.572 & 8.783 & 28.643 \\
\hline
\end{tabular}

Fonte: IPEA (2003) 
De acordo com a tabela 2.3, os acidentes com mortos apresentam um menor número de veículos envolvidos, entretanto apresentam custo por acidente cerca de 8 vezes maior que os acidentes com feridos e cerca de 44 vezes maior que os acidentes sem vítimas.

\subsubsection{Definição, Classificação e Tipos de Acidentes de Trânsito}

De acordo com o Departamento Nacional de Trânsito - DENATRAN (2007), acidente de trânsito é um evento não intencional, envolvendo pelo menos um veículo, motorizado ou não, que circula por uma via para trânsito de veículos.

Para IPEA (2003), acidente de trânsito é um evento ocorrido na via pública, seja ela rua ou calçada, proveniente do trânsito de veículos e pessoas. Este evento pode resultar em danos humanos e materiais ou em cada um deles isoladamente. Abrange não somente colisões entre veículos, mas também choques com objetos fixos, queda de pedestres e ciclistas, capotagem, atropelamento e tombamento.

Já, para Ferraz e Raia Jr. (2005) um acidente de trânsito é um evento não intencional, podendo ser caracterizado como uma colisão, no caso de envolver dois veículos em movimento; um atropelamento, quando envolver um veículo em movimento e um pedestre; ou um choque, quando envolver um veículo e um objeto fixo (como poste guia, casa, sinal de trânsito, propaganda comercial, etc). Independente de ocorrer colisão ou choque, o acidente de trânsito pode resultar em danos materiais e/ou humanos, dependendo da intensidade do ocorrido. Atropelamentos sempre geram danos humanos.

Os acidentes de trânsito podem ser classificados em duas categorias distintas: quanto à gravidade e quanto à tipologia. As vítimas dos acidentes de trânsito podem ser classificadas quanto ao estado físico. 
Segundo Ferraz e Raia Jr. (2005), quanto à gravidade no Brasil utiliza-se a classificação adotada pela Polícia Militar, na qual estão descritas três categorias de acidentes: i) sem vítimas; $i$ ) com vítimas (fatais ou feridos) não pedestres; e, iii) atropelamentos, que se pressupõe ser sempre um acidente com vítimas.

De acordo com a Associação Brasileira de Normas Técnicas - ABNT (1989), através da Norma NBR 10.697/89, Ferraz e Raia Jr. (2005) e Gold (1998), quanto à tipologia, os acidentes de trânsito podem ser classificados em:

- Colisão traseira: define-se como a colisão entre dois veículos em movimentos na mesma direção e no mesmo sentido;

- Colisão frontal: trata-se da colisão entre dois veículos em movimento, na mesma direção e em sentidos opostos;

- Colisão transversal (abalroamento transversal): corresponde à colisão entre dois veículos em direções aproximadamente perpendiculares;

- Colisão lateral (abalroamento lateral): corresponde a colisão entre dois veículos, havendo o contato na parte lateral, na mesma direção, no mesmo sentido ou em sentidos opostos;

- Choque: remete-se ao acidente entre um veículo em movimento e um obstáculo parado, tais como veículo estacionado, poste, árvore, muro, gradil, defensa, etc.;

- Atropelamentos: tipo de acidente no qual um pedestre ou um animal é atingido por um veículo (motorizado ou não-motorizado); 
- Tombamento: caracterizado por envolver um só veículo, em que um dos lados do veículo fica em contato com o chão, ao final do acidente;

- Capotagem: qualquer acidente em que o teto do veículo toma contato com o chão, pelo menos uma vez, durante o acidente;

- Engavetamento: definido como a colisão de três ou mais veículos, em uma mesma direção em um mesmo sentido ou em sentidos contrários, com um veículo atrás do outro, podendo ser por colisão traseira ou podendo incluir colisões frontais; e,

- Combinação: trata-se da união de dois ou mais tipos de acidentes já descritos anteriormente.

A Figura 2.1 exemplifica os tipos de acidentes descritos anteriormente. 


\begin{tabular}{l} 
Colisão traseira \\
Colisão frontal \\
Colisão transversal \\
Colisão lateral \\
Chopotagem \\
Choque \\
Atropelamento \\
\hline
\end{tabular}

Figura 2.1: Tipos de acidentes de trânsito.

Fonte: Simões (2001).

Segundo a ABNT (1993), através da Norma NBR 12.898/93, as vítimas dos acidentes de trânsito podem ser classificadas em: i) fatal: quando a vítima falecer em razão dos ferimentos recebidos no local do acidente, ou depois de socorrida no período até a conclusão do relatório de acidente; ii) grave: quando a vítima sofrer ferimentos graves que exijam tratamento médico mais prolongado, por exemplo: ferimentos cranianos, fraturas em geral, cortes profundos, grandes extensões de ferimentos aparentes (com vidro, fogo, material 
abrasivo, etc.); iii) leve: quando a vítima sofrer ferimentos leves, como lesões superficiais, que não exijam tratamento médico prolongado; e, iv) ileso: quando a vítima não sofrer qualquer tipo de ferimento aparente, nem apresentar sintomas ou queixas de lesões internas.

Nos Estados Unidos, utiliza-se a escala AIS (Abbreviated Injury Scale) para a classificação das vítimas dos acidentes de trânsito, conforme Tabela 2.4.

Tabela 2.4: Escala AIS dos acidentes de trânsito.

\begin{tabular}{ccl}
\hline $\begin{array}{c}\text { Código } \\
\text { AIS }\end{array}$ & $\begin{array}{c}\text { Nível de } \\
\text { severidade } \\
\text { das lesões }\end{array}$ & \multicolumn{1}{c}{ Tipos de lesões } \\
\hline 1 & Leve & $\begin{array}{l}\text { Escoriações superficiais e lacerações da pele, } \\
\text { queimaduras de primeiro grau, pequena lesão na cabeça } \\
\text { com dores ou tonturas leves, etc. }\end{array}$ \\
\hline 2 & Média & $\begin{array}{l}\text { Maiores escoriações e lacerações da pele, } \\
\text { inconsciência inferior a 15 minutos, quebra ou } \\
\text { amputação de dedos, fratura da bacia, etc. }\end{array}$ \\
\hline 3 & Séria & $\begin{array}{l}\text { Lacerações mais severas, fraturas de costelas, contusão } \\
\text { de órgãos abdominais, fratura ou amputação de mãos, } \\
\text { pés ou braços, inconsciência superior a 15 minutos, } \\
\text { etc. }\end{array}$ \\
\hline 4 & Grave & $\begin{array}{l}\text { Ruptura do baço, fratura da perna, perfuração do tórax, } \\
\text { inconsciência inferior a 24 horas, etc. }\end{array}$ \\
\hline 5 & Crítica & $\begin{array}{l}\text { Fratura da espinha com ruptura, queimaduras extensas } \\
\text { de segundo e terceiro graus, inconsciência superior a } \\
\text { 24 horas, etc. }\end{array}$ \\
\hline
\end{tabular}

Fonte: TRB (1984).

\subsubsection{Principais Fatores de Ocorrência dos Acidentes de Trânsito}

Para Gold (1998), os principais fatores que podem ocasionar a ocorrência de acidentes de trânsito são: $i$ ) homem; ii) veículo; iii) via e meio ambiente; e, $i v$ ) institucional/social. A partir do momento em que estes fatores são desagregados e correlacionados entre si, é possível conhecê-los melhor. Desta forma, procura-se associar a ocorrência dos acidentes de trânsito à seis fatores, segundo Raia Jr. (2004): i) fator humano; ii) fator veicular; iii) fator viário; $i v$ ) fator climático; v) fator uso e ocupação do solo; e, vi) fator institucional e social. 


\section{- Fator Humano}

Conforme Raia Jr. (2004), no fator humano são considerados o comportamento, a educação e o preparo do cidadão para o trânsito através do respeito à legislação, ao uso de equipamentos de segurança pessoal, além das condições físicas e psicológicas do indivíduo. Com relação às condições físicas, citam-se: o sono, a fadiga, o uso de álcool ou drogas, as distorções visuais. Já, com relação às condições psicológicas, citam-se: a tensão nervosa e a distração dos usuários do sistema viário.

Para Simões (2001), além dos fatores humanos citados anteriormente, deve-se considerar também o treinamento para a aquisição de habilidade concomitantemente com o comportamento, a educação e o preparo do cidadão, obtidos através do respeito à legislação.

Além desses fatores, para Hoffmann e Legal (2004) no fator humano destacam-se a busca intencional de riscos e de emoções intensas, condutas interferentes e as distrações; a experiência, por excesso ou falta, a respeito do veículo ou da via.

Mais especificamente com relação ao transporte público por ônibus, de acordo com Ferraz e Torres (2004), o comportamento dos operadores (motorista e cobrador) também corresponde a um fator que pode ocasionar a ocorrência de acidentes. Neste fator, devem ser observados os seguintes aspectos: $i$ ) condução do veículo com habilidade e cuidado (direção defensiva); ii) tratamento adequado para com os passageiros; e, iii) espera dos tempos de embarque e desembarque dos passageiros. 


\section{- Fator Veicular}

De acordo Raia Jr. (2004), os aspectos mais importantes ligados ao fator veicular são aqueles que envolvem o projeto do veículo (equipamentos de segurança, potência do motor, estabilidade, capacidade de frenagem, etc.), como também os associados com as condições de manutenção e conservação dos veículos (motor, luzes, pneus, freios, amortecedores, limpadores de pára-brisas, suspensão, tamanho dos veículos, etc.).

\section{- Fator Viário}

Para Raia Jr. (2004), com relação ao fator viário, os principais fatores são os referentes à: $i$ ) geometria (largura, declividade, superelevação, tipos de intersecções, etc.); ii) sinalização horizontal e vertical (existência, visibilidade, conservação e posição); iii) regulamentação e operação da via (mão única ou dupla, hierarquização, estacionamento, etc.); iv) pavimentação (tipo, drenagem e conservação, etc.); e, v) fluxo de tráfego (quantidade e composição da frota de veículos, conflitos de tráfego).

Segundo Ferraz, Forte e Simões (1999), no tocante à geometria, a definição da largura da via está condicionada ao volume de tráfego, tipos de veículos, velocidade de operação, necessidade de estacionamento na via, intensidade do fluxo de pedestres, etc. Para a definição dos limites de declividades máximas e raios de curvatura vertical, é fundamental considerar as condições topográficas da região. Com relação às interseções, quatro tipos podem ser verificados: $i$ ) interseção simples com 3 (três) aproximações; ii) interseção simples com 4 (quatro) aproximações; iii) interseção simples com múltiplas aproximações; e, $i v$ ) interseções canalizadas. 
Em estudo realizado por Abdel-Aty, Radwan e Yan (2005), verificou-se que a melhoria das condições geométricas das interseções reduz os tempos de reação e de parada dos motoristas e, quando possível, deve-se evitar locá-las em trechos de curvas horizontais e verticais.

Segundo Mon-Ma (2005), nas áreas urbanas bem adensadas (ou seja, que possuem grande concentração de edificações) da cidade de São Carlos, onde o controle de tráfego da interseção é realizado através de placas de regulamentação de parada obrigatória ou semáforo, todos os tipos de colisão são freqüentes. Exceção é feita às colisões frontais, que são mais freqüentes em interseções localizadas em áreas sem adensamento.

No tocante à hierarquização, as vias podem ser classificadas em quatro categorias, de acordo com o Código de Trânsito Brasileiro - CTB (BRASIL, 1997):

- Via de trânsito rápido: caracterizada por acessos especiais com trânsito livre, sem intersecções em nível, sem acessibilidade direta aos lotes lindeiros e sem travessia de pedestres em nível. O fluxo é alto e a velocidade máxima recomendada é de $80 \mathrm{~km} / \mathrm{h}$;

- Via arterial: caracterizada por intersecções em nível, geralmente controlada por semáforo, com acessibilidade aos lotes lindeiros e às vias secundárias e locais, possibilitando o trânsito entre as regiões da cidade. O fluxo é alto e a velocidade máxima recomendada é de $60 \mathrm{~km} / \mathrm{h}$;

- Via coletora: destinada a coletar e distribuir o trânsito que tenha necessidade de entrar ou sair das vias de trânsito rápido ou arteriais, possibilitando o trânsito dentro das regiões da cidade. O fluxo pode ser alto ou médio e a velocidade máxima recomendada é de $40 \mathrm{~km} / \mathrm{h}$; e, 
- Via local: caracterizada por intersecções em nível não semaforizadas, destinadas apenas ao acesso local ou a áreas restritas. O fluxo em geral é pequeno e a velocidade máxima recomendada é de $30 \mathrm{~km} / \mathrm{h}$.

De acordo com Campos e Sampedro (2006), as vias também podem ser classificadas de acordo com a sua função na estrutura urbana, de acordo com os seguintes critérios: $i$ ) importância relativa para a cidade; ii) tipos de usuários presentes; iii) uso do solo predominante; iv) composição do tráfego; v) acessibilidade às propriedades; e, vi) tipo de tráfego existente (local ou de passagem).

A quantificação do volume de tráfego presente nas vias que se interceptam, possibilita especificar o tipo de controle de tráfego a ser utilizado. Os tipos de controle freqüentemente utilizados são os seguintes: $i$ ) interseção com sinal de parada obrigatória ou dê a preferência indicado para interseções com volumes médios de tráfego; ii) cruzamento com semáforo indicado para interseções com alto volume de tráfego; iii) rotatórias; e, iv) retornos. Especificamente com relação ao uso de semáforos, também é necessário informar o número de faixas das vias envolvidas, o volume total dos dois sentidos da via principal e o volume do sentido de maior movimento da via secundária (FERRAZ, FORTE E SIMÕES, 1999).

\section{- Fator Climático}

Com relação ao fator climático, os principais aspectos são: $i$ ) ofuscamento, devido à incidência de raios solares e fechos luminosos de faróis no pára-brisa; ii) chuva; iii) existência de neblina; e, $i v$ ) fumaça, etc.

Principalmente em aproximações que apresentam geometria inadequada ou presença de semáforos, a incidência dos raios solares pode, em determinadas situações, ocasionar o 
fenômeno denominado cegueira momentânea, impossibilitando que o condutor veja o veículo na via transversal, bem como a presença de sinalização semafórica ou a cor do foco semafórico no instante da travessia. Em situações nos quais os veículos trafegam na mesma direção, mas em sentidos opostos, o mesmo fenômeno pode ser verificado em decorrência dos fechos luminosos dos faróis dos veículos envolvidos.

De acordo com Setti (2000), a incidência de chuva, associada às condições da face de contato (estado de conservação dos pneus e do pavimento), ao tipo de borracha, ao desenho dos sulcos da banda de rodagem e ao aumento da velocidade, contribuem para o decréscimo do valor do coeficiente de aderência, reduzindo a eficácia da frenagem e contribuindo para a ocorrência de acidentes. A Tabela 2.5 mostra os coeficientes de aderência válidos para 11 tipos de pavimento.

Tabela 2.5: Coeficientes de aderência típicos para pneus.

\begin{tabular}{lc}
\hline \multicolumn{1}{c}{ Superfície } & $\begin{array}{c}\text { Coeficientes de } \\
\text { Aderência }\end{array}$ \\
\hline 1. Asfalto ou concreto seco & $0,80-0,90$ \\
2. Concreto molhado & 0,8 \\
3. Asfalto molhado & $0,50-0,70$ \\
4. Pedrisco & 0,6 \\
5. Terra firme seca & 0,7 \\
6. Terra solta seca & 0,45 \\
7. Terra firme úmida & 0,55 \\
8. Areia seca & 0,2 \\
9. Areia úmida & 0,4 \\
10. Neve & 0,2 \\
11. Gelo & 0,1 \\
\hline
\end{tabular}

Fonte: SETTI (2000).

Conforme Tabela 2.5, o asfalto sob condições chuvosas, diminui o coeficiente de aderência entre 22,2 e $37,5 \%$, ao passo que o concreto diminui de 0 a $11,1 \%$, sendo o asfalto 
mais inseguro sob condições chuvosas. Além disto, a ocorrência de chuvas também diminui a visibilidade, aumentando as chances de ocorrência de acidentes.

Com relação às condições do tempo, deve-se ressaltar que a presença de neblina não é comum, exceto em trechos de serra; ao passo que a presença de fumaça ocorre geralmente em regiões canavieiras como também em áreas urbanas que apresentam um grande número de terrenos desocupados e sem manutenção. Na Tabela 2.6, tem-se a quantidade de acidentes em função das condições do tempo.

Tabela 2. 6: Condições do tempo e quantidade de acidentes.

\begin{tabular}{cc}
\hline Condições do Tempo & Quantidade de Acidentes \\
\hline Bom & 90.396 \\
Chuva & 20.351 \\
Neblina & 3.826 \\
Total de acidentes & $\mathbf{1 1 4 . 5 7 3}$ \\
\hline
\end{tabular}

Fonte: Polícia Rodoviária Federal ${ }^{1}$ (2003 apud Ministério dos Transportes, 2003)

Conforme Tabela 2.6, a quantidade de acidentes de trânsito ocorrida em condições com o tempo bom, representa $78,90 \%$ do total de acidentes. Considerando em condições chuvosas, este percentual cai para $17,76 \%$, enquanto que em condições de neblina tem-se apenas 3,34\%. A maior ocorrência de condição meteorológica com o tempo bom pode ser atribuída à maior quantidade de dias do ano com esta condição, quando comparada às demais.

Diante do exposto, verifica-se que os fatores climáticos contribuem para a ocorrência dos acidentes de trânsito, através da redução da visibilidade e do atrito pneu-pavimento, cabendo ao ser humano a implantação de sinalizações de advertência e de medidas de engenharia.

\footnotetext{
${ }^{1}$ POLÍCIA RODOVIÁRIA FEDERAL. Estatísticas de Acidentes de Trânsito nas Rodovias Federais do País 2003. Disponível em http://www.transportes.gov.br/Pare/D_Estat2003.htm. Acesso em 20 de março de 2006.
} 


\section{- Fator Uso e Ocupação do Solo}

De acordo com Cardoso (1999), os eventos ocorridos no sistema viário, como acidentes de trânsito, sofrem grande influência do uso do solo presente na região.

Os fatores ligados ao uso e ocupação do solo são os relativos à existência de áreas comercial, industrial ou residencial; interferências visuais de imóveis; Pólos Geradores de Tráfego - PGT, os quais podem ser comerciais ou de serviços (supermercados, pontos de ônibus, escolas, shopping centers, estádios esportivos, etc.) e que, devido à sua alta atratividade de viagens, acarretam o aumento do volume de tráfego no local e nas áreas próximas.

De acordo com Portugal e Goldner (2003), um Pólo Gerador de Tráfego - PGT corresponde a um local ou instalações de natureza distintas que possuem em comum o desenvolvimento de atividades de tal escala que ocasionam um significativo número de viagens e externalidades potenciais, não somente nos sistemas viário e de transportes, mas na organização do uso do solo e do contexto socioeconômico. Esses locais ou empreendimentos necessitam de grandes espaços para estacionamento, carga/descarga e embarque/desembarque, sendo que, em alguns casos, podem interferir na acessibilidade da região do entorno como também agravar as condições de segurança de veículos e pedestres.

De acordo com Gold (1998), a localização de um pólo gerador de tráfego influi na freqüência, na gravidade e no tipo dos acidentes de trânsito. Dependendo do uso e ocupação do solo e presença ou não de PGT's, as vias podem apresentar maior ou menor concentração de pessoas e veículos, gerando acidentes de características distintas. Em locais com maior concentração de pessoas e de veículos ocorre a maior freqüência de acidentes, porém com menor gravidade comparada com locais que apresentam menor concentração de pessoas e de 
veículos, onde ocorrem maiores velocidades. Isso acontece porque o congestionamento e o alto fluxo de pedestres, associados à sinalização semafórica e fiscalização mais efetiva, contribuem para a redução da velocidade dos veículos e da gravidade dos acidentes.

\section{- Fator Institucional e Social}

Segundo Gold (1998), os aspectos envolvidos neste fator são: i) a regulamentação (legislação); e, ii) o policiamento (fiscalização). Com relação à fiscalização, observam-se a obediência à legislação de trânsito referente à sinalização, o posicionamento e uso de equipamentos de segurança do veículo e às regras de circulação, através da utilização de equipamentos automáticos de fiscalização, tais como radares, medidores de velocidade e câmaras fotográficas, além de agentes de trânsito e policiais militares.

A combinação dos fatores humano, veicular, viário, climático, uso e ocupação do solo e institucional e social, quase sempre, implícita ou explicitamente, estão presente na ocorrência de acidentes. A Figura 2.2 apresenta estes seis fatores, segundo Raia Jr. (2004). 


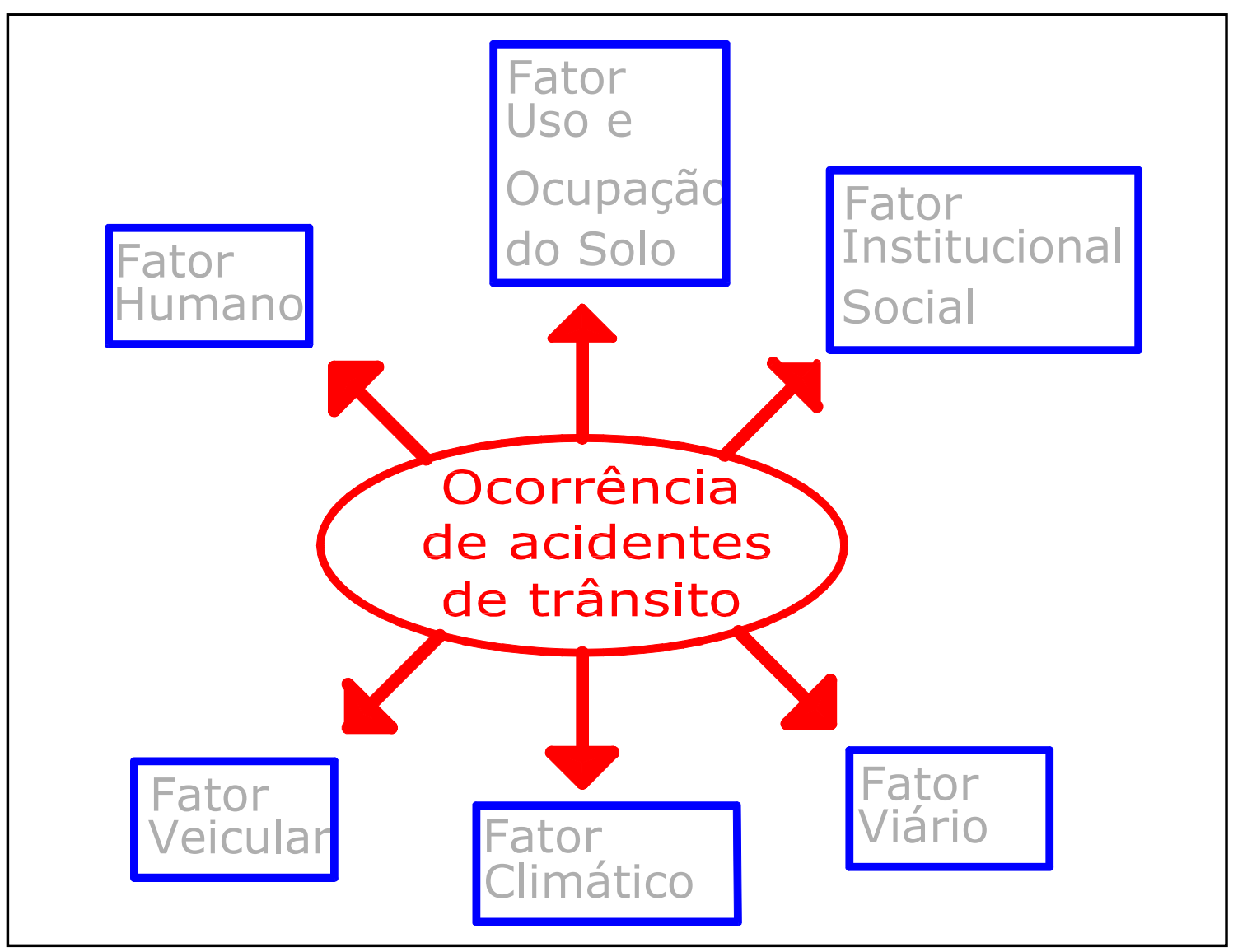

Figura 2.2: Conjunto de fatores que podem influenciar a ocorrência de acidentes de trânsito. Fonte: Raia Jr (2004).

De acordo com Raia Jr. (2004), a combinação dos vários fatores citados anteriormente pode aumentar a probabilidade de ocorrência de acidentes em determinados locais. Para definir quais ações deverão ser utilizadas para a redução dos acidentes de trânsito, é necessário definir quais os reais fatores que contribuem para a ocorrência dos mesmos, sejam eles em menor ou maior grau, e qual a relação existente entre cada um deles para que posteriormente possam ser aplicadas medidas mistas visando obter resultados, no mínimo, satisfatórios.

Além disso, é necessário ter conhecimento sobre os principais fatores que influenciam na gravidade dos acidentes de trânsito, para, em conjunto, aplicar as medidas necessárias e suficientes para a redução da ocorrência dos mesmos. Para Ferraz e Raia Jr. (2005), os 
principais fatores são: $i$ ) velocidade; ii) não utilização de equipamentos de segurança; e, iii) veículos inadequados.

\section{- Velocidade}

A alta velocidade é a principal causa da ocorrência dos acidentes de trânsito que resultam em vítimas fatais. De acordo com OMS (2004), o excesso de velocidade contribui para cerca de $30 \%$ das mortes no trânsito nos países desenvolvidos e $50 \%$ nos países não desenvolvidos.

A Figura 2.3 mostra a probabilidade de ocorrer morte em função da velocidade do veículo em uma colisão, nos seguintes casos: pedestre atropelado (termo que se ajusta também para ciclistas e motociclistas, devido à fragilidade dos mesmos no trânsito), ocupante em choque lateral e ocupante em choque frontal.

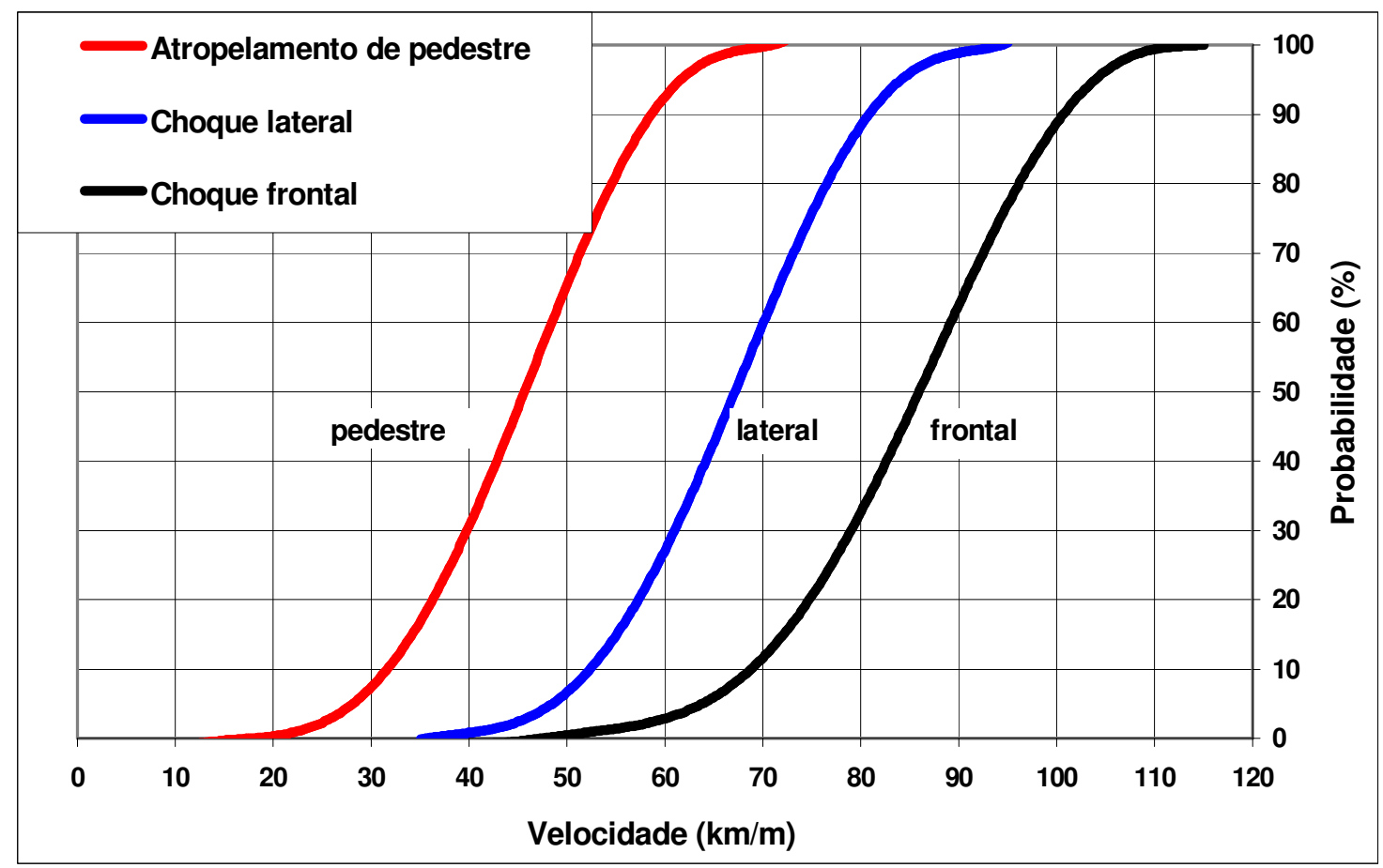

Figura 2.3: Probabilidade da existência de vítima fatal em função da velocidade e do tipo de acidente.

Fonte: Lund Institute of Tecnology, da Suécia. 
De acordo com a Figura 2.3, observa-se que para uma mesma velocidade, a probabilidade de ocorrer acidentes com vítima fatal é maior para pedestres (também para ciclistas e motociclistas), depois para choque lateral e, por último, para choque frontal. Também se pode constatar que para reduções de velocidade relativamente pequenas ocorre uma grande queda da probabilidade de morte para todos os tipos de acidentes.

Ressalta-se que este gráfico foi desenvolvido no Instituto de Tecnologia de Lund, na Suécia, um país que apresenta condições das vias, idade média da frota, educação no trânsito e uma cultura de priorização da segurança viária totalmente diferente da apresentada no Brasil.

\section{- Não Utilização de Equipamentos de Segurança}

Outro fator que influencia na gravidade dos acidentes de trânsito é a não utilização de equipamentos de segurança, conforme Ferraz e Raia Jr. (2005), dentre os quais apresentam-se:

- Cinto de segurança: no caso de uma colisão frontal, reduz o valor da força de impacto sobre o ocupante; faz com que a força atue em partes mais resistentes do corpo (tórax e pélvis em vez da cabeça) e distribui essa força em uma área maior, reduzindo a pressão localizada;

- Cadeiras para crianças: independente do tipo utilizado, seu emprego correto ajuda a reduzir em cerca de $71 \%$ as mortes de bebês e de $54 \%$ de crianças maiores;

- “Airbag" (bolsa de ar): no caso de uma colisão frontal, distribui a força do impacto mais homogeneamente ao longo do corpo do ocupante e evita que a cabeça e os membros superiores sejam lançados para frente em relação ao tórax; e, 
- Capacete: quando usado corretamente, reduz em cerca de $30 \%$ o risco de mortes em acidentes e em $70 \%$ o risco de lesões sérias na cabeça.

\section{- Veículos Inadequados (Motocicletas)}

De acordo com Vasconcellos (1985), embora a motocicleta apresente a vantagem de ser eficiente do ponto de vista energético e de circulação, apresenta a desvantagem de possuir pequenas dimensões que, muitas vezes, a torna imperceptível pelos condutores dos automóveis, transformando-a em um dos modos de transporte que apresenta maior risco de morte para com seus usuários. Nas Tabelas 2.7 e 2.8 têm-se as taxas de mortalidade por modo de transporte em alguns países da União Européia, conforme dados da European Transport Safety Council - ETSC (2003).

Tabela 2.7: Taxa de mortalidade por modo de transporte por 100 milhões de pass.km nos países da União Européia.

\begin{tabular}{lc}
\hline \multicolumn{1}{c}{ Modo de transporte } & $\begin{array}{c}\text { Taxa de mortalidade por 100 } \\
\text { milhões de pass.km }\end{array}$ \\
\hline Motocicleta, lambreta e assemelhados & 13,8 \\
A pé & 6,4 \\
Bicicleta & 5,4 \\
Carro, perua e camioneta & 0,7 \\
Ônibus e bonde & 0,07 \\
Balsa & 0,25 \\
Avião & 0,035 \\
Trem & 0,035 \\
\hline
\end{tabular}

Fonte: ETSC (2003).

Conforme dados da Tabela 2.7, para os países da União Européia, a taxa de mortalidade por 100 milhões de pass.km quando se utiliza o modo motocicleta, lambreta e assemelhados é cerca de 20 vezes maior em relação ao carro e cerca de 200 vezes em relação ao ônibus. 
Tabela 2.8: Taxa de mortalidade por modo de transporte por 100 milhões de pass.horas de viagem nos países da União Européia.

\begin{tabular}{lc}
\hline \multicolumn{1}{c}{ Modo de transporte } & $\begin{array}{c}\text { Taxa de mortalidade por 100 } \\
\text { milhões de pass.horas de viagem }\end{array}$ \\
\hline Motocicleta, lambreta e assemelhados & 440 \\
Bicicleta & 75 \\
A pé & 25 \\
Carro, perua e camioneta & 25 \\
Ônibus e bonde & 2 \\
Avião & 16 \\
Balsa & 8 \\
Trem & 2 \\
\hline Fonte: ETSC (2003)
\end{tabular}

De acordo com a Tabela 2.8, a taxa de mortalidade por 100 milhões de pass.horas de viagem ao se utilizar a motocicleta, lambreta e assemelhados é cerca de 18 vezes maior em relação ao carro e 220 vezes maior em relação ao ônibus.

Diante dos dados apresentados, verifica-se a vulnerabilidade de motocicletas, lambretas e assemelhados no trânsito, uma vez que estas não apresentam proteção alguma para seus usuários, diante de qualquer imprevisto na via pública ou mesmo qualquer manobra evasiva que tenha que ser realizada.

\subsubsection{Técnicas Utilizadas no Estudo da Segurança do Trânsito}

Para estudar a segurança de trânsito, pode-se focar, isoladamente, ou em conjunto, em três técnicas diferentes: $i$ ) Análise do Banco de Dados de Acidentes de Trânsito (ABDAT); ii) Análise de Conflitos de Tráfego (ACT); e, iii) Auditoria de Segurança Viária (ASV).

\section{- Análise do Banco de Dados de Acidentes de Trânsito (ABDAT)}

Um banco de dados é definido como sendo um conjunto de dados que são armazenados, organizados, expandidos, atualizados e recuperados, em um sistema de 
informação, cuja função é servir a uma ou mais aplicações, independentemente do programa utilizado, conforme Raia Jr. (2004).

Utilizando um Banco de Dados de Acidentes de Trânsito (BDAT) obtém-se, dentre outros itens, o número total de acidentes na cidade, o número de mortes e vítimas não fatais, cruzamentos e trechos de vias com um maior número de acidentes. Além disso, é possível também realizar o levantamento dos acidentes por tipo, de acordo com os dias da semana, horários, vítimas, etc.

Para Tourinho (2002), o objetivo da análise dos dados de acidentes é identificar e localizar dentro do sistema viário os locais que apresentam elevados índices de acidentes (taxas, frequências ou ambas), a partir dos quais se obtém os locais que necessitam de intervenção.

\section{- Análise de Conflitos de Tráfego (ACT)}

Segundo Pietrantônio (1991), os dados de acidentes de trânsito sempre foram a fonte principal de informações dos acidentes, entretanto nem todas as cidades dispõem de um banco de dados que contenha todas as informações dos acidentes, notadamente a dos países menos desenvolvidos. No entanto, somente a partir de 1967 foram empreendidos esforços para a formulação de uma técnica de análise da operação de tráfego baseada em observações, tendo início com pesquisadores da GMRL - General Motors Research Laboratory nos EUA. Nos anos 70 e 80, a partir da realização de dois congressos internacionais de avaliação de técnicas de análise de conflitos no tráfego, foi criado o ICTCT - Institute for Cooperation on Traffic Conflict Techniques, uma instituição internacional voltada exclusivamente para estes estudos. Mais recentemente foi criado pelo FHWA - Federal Highway Administration dos EUA, um manual voltado exclusivamente para a ACT. 
Para Hydén (1987), um conflito de tráfego pode ser definido como uma situação na qual dois ou mais usuários da via se aproximam no espaço e no tempo com elevada probabilidade de ocorrer uma colisão, caso nenhum dos envolvidos execute uma manobra evasiva; manobras estas que podem ser identificadas como uma frenagem, um desvio ou uma aceleração dos usuários da via (motoristas, pedestres, ciclistas, etc.).

Para Muhlrad (1988), um conflito é um evento envolvendo dois ou mais usuários da via (ou um usuário e um elemento externo), em que, a ação de um usuário (ou a aproximação de um elemento externo) resulta em uma manobra evasiva do outro usuário envolvido, com o objetivo de evitar uma colisão ou um atropelamento.

De acordo com Pietrantônio (1991), a técnica de Análise de Conflitos de Tráfego (ACT) visa diagnosticar e avaliar, mais precisamente e detalhadamente, os problemas de segurança de trânsito, bem como os efeitos de possíveis alternativas de intervenção, através de uma forma de observação direta. Ainda de acordo com o autor, alguns pontos favoráveis são apresentados, tais como: $i$ ) os conflitos são eventos de fácil observação direta, ao contrário dos dados de acidentes, que levam um grande tempo para serem acumulados; ii) o conflito representa um perigo potencial e os acidentes são realizações posteriores; iii) o estudo de conflitos pode ser feito imediatamente sem que seja necessário esperar que os acidentes ocorram; e, $i v$ ) as definições utilizadas em conflitos de tráfego são baseadas em tipologia de acidentes, o que permite utilizá-las como medidas próximas de acidentes.

Entretanto, apresenta alguns pontos desfavoráveis, conforme Pietrantônio (1991) e Meirelles (2003), tais como: i) nem todos os acidentes são precedidos de uma manobra evasiva; ii) a subjetividade envolvida na pesquisa pode comprometer o diagnóstico; iii) necessidade de pesquisa em campo; e, $i v$ ) questão da qualidade dos avaliadores, independente 
do treinamento, uma vez que é necessário que os mesmos se conscientizem que levantamentos mal realizados podem arruinar toda uma pesquisa.

Muito embora a ACT apresente um número igual de vantagens e desvantagens, no Brasil ainda não é massivamente empregada em virtude de alto custo monetário dos treinamentos, ocasionando em um pequeno número de pessoas aptas a aplicarem esta técnica.

\section{- Auditoria de Segurança Viária (ASV)}

De acordo com Raia Jr. (2004), Auditoria de Segurança Viária (ASV) são avaliações formais que têm como foco aspectos relacionados com a segurança, partindo da concepção do projeto até a etapa operacional. Tem como propósito identificar problemas de segurança (tanto para todos os usuários da via, como para os afetados pelo projeto viário) e garantir que medidas sejam consideradas completamente para a eliminação ou redução dos problemas.

Esta técnica foi desenvolvida na década de 80 pelo britânico Malcolm Bulpitt que, primeiramente aplicou os conceitos no setor ferroviário e, em seguida, no setor rodoviário, na Inglaterra. Em 1990 foram publicadas as Diretrizes para a Auditoria de Segurança Viária, que mais tarde se tornaram obrigatórias e, no mesmo ano, a ASV foi introduzida na Austrália e na Nova Zelândia, através da realização de auditoria de uma rodovia já existente, a Pacific Highway, utlizando "checklists" especialmente preparados. No final da década de 90, a técnica foi implantada no Canadá, Dinamarca e Estados Unidos.

Para Nodari e Lindau (2001), o objetivo principal da ASV é diminuir a probabilidade de ocorrência de acidentes de trânsito através da realização de vistorias periódicas, cujo foco é a segurança, enquanto que o objetivo secundário é a minimização da ocorrência e da severidade dos acidentes. 
Segundo Federal Highway Administration - FHWA (1997), a ASV possui cinco estágios que abrangem desde a concepção das vias, com a possibilidade de introdução de modificações para melhorar as condições de segurança antes do início da operação até sua operação propriamente dita, com a aplicação de medidas para alterar e melhorar as condições de segurança. Os cinco estágios são: $i$ ) estágio 1 - exeqüibilidade; ii) estágio 2 - projeto preliminar; iii) estágio 3 - projeto definitivo; iv) estágio 4 - pré-abertura de vias; e, v) estágio 5 - vias em operação.

Ainda de acordo com FHWA (1997), a ASV apresenta alguns pontos positivos, tais como: $i$ ) redes viárias seguras; $i$ i) redução de custos totais de dispositivos viários; iii) melhoria da engenharia de segurança viária; e, $i v$ ) redução da necessidade de modificação do sistema de circulação das vias após a sua operação, entre outros fatores. Entretanto apresenta alguns pontos negativos, tais como: $i$ ) difícil aceitação por parte de algumas agências locais (órgãos gestores de trânsito) em adotarem a ASV; ii) não aceitação de alguns profissionais em terem seus projetos revisados por outros técnicos; e, iii) dificuldade de contratação de profissionais experientes quando comparados aos profissionais menos experientes e com faixa salarial menor, entre outros.

Porém, verifica-se que no Brasil, ainda não há uma disseminação do conhecimento e da aceitação da ASV, portanto não há uma aplicação massiva na malha viária nacional.

\subsubsection{Coleta e Tipos de Dados sobre os Acidentes de Trânsito}

De acordo com Ministério dos Transportes (2002), na maioria dos municípios brasileiros, as ocorrências de acidentes de trânsito são registradas pela Polícia Militar ou pela Polícia Civil, dependendo se o atendimento ao acidente é realizado ou não no local de ocorrência. 
No primeiro caso, as informações são registradas por policiais militares no Boletim de Ocorrência (BO) e no segundo caso são registradas em delegacias especializadas por meio de policiais civis que lavram o Registro de Ocorrência (RO). A diferença entre esses dois casos reside na exatidão das informações, pois no primeiro caso as informações são colhidas no local do acidente e no segundo caso, após a ocorrência dos mesmos, podendo haver algumas informações inexatas, o que requer uma criteriosa análise das mesmas.

De um modo geral, o número real de acidentes que resultam em danos materiais é superior ao registrado pelas Polícias Militar ou Civil, uma vez que nem todos são relatados aos órgãos competentes. Há muitos casos nos quais as partes envolvidas entram em consenso, não havendo, segundo elas, a necessidade do registro do acidente em BO’S ou RO’S. Entretanto, no caso específico dos acidentes envolvendo veículos de transporte coletivo, devido à exigência do cumprimento de procedimentos internos das próprias empresas operadoras, para qualquer acidente no qual os operadores se envolvam é necessário que seja realizado o Boletim de Ocorrência (BO), até mesmo como uma forma da empresa operadora se defender judicialmente contra qualquer acusação.

A partir do momento em que a técnica utilizada para estudar a segurança de trânsito é um Banco de Dados de Acidentes de Trânsito (BDAT), torna-se imprescindível a coleta e a análise dos dados dos acidentes de trânsito, pois os mesmos são extremamente importantes para a realização de projetos que visem a sua redução. Em virtude disto, os BO'S e os RO’S constituem-se na principal fonte de dados e de informações dos acidentes de trânsito (GEIPOT, 1999).

Os dados a serem coletados nos BO'S e RO’S, segundo DENATRAN (2007) e Raia Jr. (2004), são: i) localização; ii) momento do acidente; iii) características do tempo; iv) características do pavimento; v) características da extensão dos danos materiais; vi) 
características das pessoas envolvidas; vii) características do condutor; viii) características do acidente; $i x)$ características do veículo; e, $x$ ) características da vítima.

Esses dados são importantes, pois permitem identificar os pontos, trechos ou áreas mais críticos em relação à ocorrência de acidentes de trânsito, possibilitando assim mapeá-los e analisá-los, de forma a identificar onde há carência de segurança, na tentativa de diminuí-la ou até suprimí-la da estrutura urbana.

\subsubsection{Localização e Análise dos Acidentes de Trânsito}

Ao se analisar os BO’S e RO’S, verifica-se que os mesmos possuem a localização dos acidentes através de um endereço, ou de um cruzamento de vias. Esta localização corresponde a um local específico, com características espaciais, podendo a ele referenciar um par de coordenadas geográficas, contendo longitude e latitude. Ou seja, os acidentes de trânsito podem ser considerados como fenômenos espaciais (RAIA Jr. et al., 2001).

Para Setti (1985), os métodos de identificação e classificação de locais inseguros, apresentam como objetivo apontar os componentes do sistema viário onde o nível de segurança esteja muito abaixo da média do sistema. Identificados esses locais, procede-se à classificação de um conjunto de locais perigosos, de forma a estabelecer prioridades para o estudo de intervenções com o objetivo de diminuir os riscos de acidentes.

Após a obtenção dos dados relacionados aos acidentes de trânsito, tal como sua identificação e classificação, pode-se iniciar o diagnóstico do problema. Este diagnóstico tem importância fundamental na análise de um sistema, pois qualquer decisão de intervenção está calcada em seu resultado (MANTOVANI, 2003). 


\subsubsection{Pontos Críticos}

Após a análise dos acidentes de trânsito, é necessário definir quais são os pontos críticos do sistema viário com relação à segurança. Apesar de não haver uma definição exata de ponto crítico, tem-se a idéia geral de ser um local na rede viária urbana em que ocorre um número real elevado de acidentes de trânsito e/ou que apresenta alta periculosidade, comparado com todos os demais pontos e com taxas críticas específicas para as muitas classificações funcionais das vias e interseções (MANTOVANI, 2003). Segundo Gold (1998), na maioria das situações verificadas, um local que naturalmente apresenta uma alta freqüência de acidentes é a interseção de duas ou mais vias, nas quais ocorrem constantemente movimentos conflitantes entre os veículos e pedestres.

Além dos conceitos de ponto crítico, também há outros conceitos relacionados, tais como os de trechos críticos e área crítica (MINISTÉRIO DOS TRANSPORTES, 2002). A diferença entre esses conceitos reside apenas na extensão da área a ser analisada.

Por trecho crítico entende-se a extensão de vias urbanas ou de rodovias, na qual é elevada a freqüência de acidentes. Nesta classificação, cada segmento viário envolvido deve ser tratado como único, incluindo muitas vezes, suas áreas adjacentes (MINISTÉRIO DOS TRANSPORTES, 2002). Através desta classificação, é possível definir um índice de periculosidade que permite estratificar as vias mais perigosas, considerando o número de ocorrências com vítimas/ano, extensões do segmento viário $(\mathrm{km})$ e os Volumes Médios Anuais de Tráfego (VMA) (MINISTÉRIO DOS TRANSPORTES, 2002). Os locais de alta periculosidade apresentam as mais altas probabilidades de condutores e/ou pedestres sofrerem um acidente de trânsito. 
Por área crítica entende-se as áreas urbanas que apresentam a maior concentração de acidentes de trânsito, devido à maior concentração de atividades na qual se situam as maiores e principais áreas de serviço, as quais atraem e produzem um grande fluxo de viagens, estando quase sempre relacionadas à localização de PGT'S (MINISTÉRIO DOS TRANSPORTES, 2002). Por esta razão, a maior concentração de acidentes ocorre habitualmente na área central, entretanto, devido à baixa velocidade do trânsito nesta zona, em geral, a freqüência de acidentes com vítimas (excluindo os atropelamentos) é relativamente menor que nas vias de alta velocidade.

Por fim, perante todas as variações de locais críticos, para definir a ordem de prioridade de análise de segurança viária é necessário verificar, de acordo com Companhia de Engenharia de Tráfego - CET (1979): i) em um primeiro momento, os locais que apresentam acidentes com maior gravidade; $i$ ) em seguida, locais com maior frequiência de acidentes; iii) posteriormente, locais com elevada periculosidade; iv) depois, os locais que apresentam crescimento recente no número de acidentes e, por fim; v) os locais que recebem reclamação do público.

\subsubsection{A Importância das Estatísticas}

A estatística é uma subdivisão da matemática que se ocupa dos métodos de coletar dados de maneira científica e com processos que devem ser seguidos para analisá-los e, a partir deles, fazer interferências válidas (ROZESTRATEN, 1988). Na área de transportes, considera-se estatística uma forma simplificada de coleta, tabulação, processamento, análise e utilização de dados. Informações de fluidez e acidentes de trânsito são essenciais para a organização em todas as escalas: do planejamento estratégico, da gestão diária, ou, simplesmente, da ordenação dinâmica dos deslocamentos e da prática cotidiana da racionalização do espaço (BALBIM, 2000). A principal vantagem da estatística de acidentes 
de trânsito é a de caracterizar eventos reais do passado, além de fornecer idéias de qualidade e de quantidade.

No Brasil, de acordo com DENATRAN (2007), valoriza-se pouco a utilização de estatísticas. Isso acontece devido a fatos diversos como: o desconhecimento da importância das informações, o alto custo das pesquisas, a necessidade de recursos humanos e materiais adequados. As comparações internacionais entre as estatísticas de acidentes apresentam dificuldades, visto que, além da heterogeneidade das definições, dos sistemas de classificações e do grau de motorização, há uma diversidade de fatores geográficos e socioeconômicos que influem na segurança viária de cada país. Na maior parte dos países em desenvolvimento, a imprecisão e a falta de homogeneidade dos dados disponíveis tornam ainda mais difícil a análise dos acidentes (RAIA Jr. e SOUZA, 2000).

\subsection{SEGURANÇA NO TRANSPORTE COLETIVO}

Verifica-se que no Brasil não há muitos estudos acerca da acidentalidade no transporte coletivo, apenas alguns estudos sobre segurança viária que incluem este modo de transporte. De acordo com IPEA (2003), considerando apenas a frota de duas empresas de ônibus na aglomeração urbana de São Paulo, o número de acidentes por veículo é de 2,23. De acordo com a Empresa Municipal de Desenvolvimento de Campinas - EMDEC (2003), na cidade de Campinas, de todos os veículos envolvidos em acidentes de trânsito ocorridos no ano de 2003, cerca de $8,0 \%$ eram ônibus que realizavam o transporte coletivo. Em estudo realizado pela Empresa de Trânsito e Transporte Urbano de Ribeirão Preto - TRANSERP (2003), considerando somente os veículos envolvidos em acidentes com vítimas, cerca de 4,0\% eram ônibus. 
Em pesquisa realizada por Albertsson e Falkmer (2005) no continente Europeu, procurou-se identificar e descrever a existência de um padrão de acidentes envolvendo o transporte coletivo urbano e intermunicipal como também o realizado por estradas rurais, considerando a gravidade e as fatalidades destes acidentes. Para o desenvolvimento da referida pesquisa, no método consideraram-se todos os tipos de acidentes envolvendo o modo de transporte especificado, a classificação dos ônibus de acordo com seu peso e com a capacidade de transporte de passageiros sentados e a Escala de Gravidade Abreviada (AIS), ressaltando-se que a definição da escala diferiu para cada país estudado.

Como resultado, obteve-se:

- A comparação entre diferentes países revelou-se válida a partir do momento em que se consideraram condições homogêneas e tamanhos de amostras iguais, além da diferença existente com relação à data da ocorrência da fatalidade entre o registro da polícia e o do hospital na qual a vítima esteve hospitalizada;

- O transporte coletivo, representado pelo ônibus, está menos envolvido em acidentes de trânsito quando comparado com os outros veículos e mais envolvido em acidentes do tipo colisão lateral e colisão traseira;

- As fatalidades envolvendo o transporte coletivo urbano e intermunicipal, corresponderam a 0,3 e $0,5 \%$, respectivamente, do número total de fatalidades ocorridas;

- Muitos acidentes ocorreram em áreas urbanas, nas quais o limite de velocidade era de $50 \mathrm{~km} / \mathrm{h}$, enquanto que muitas fatalidades (e relativamente poucos acidentes) ocorreram em áreas rurais nas quais o limite de velocidade estava entre 90 e 100 km/h; 
- Com relação às colisões, o padrão verificado foi que em sua maioria ocorreram com veículos de quatro rodas, notadamente carros, sendo que os tipos mais comuns foram as colisões frontais, seguidas das laterais e traseiras;

- O padrão dos acidentes que não envolveram outros veículos, foi caracterizado pela ocorrência de freadas bruscas e por operações de embarque e desembarque de passageiros, sem a devida precaução;

- Verificou-se que o padrão das lesões ocorridas nos passageiros era afetado pela dimensão dos veículos envolvidos, como no caso da colisão entre um veículo pequeno (automóvel) e um veículo maior (ônibus), como também pela situação do passageiro no momento da colisão (sentado ou em pé, no caso dos ônibus) e pela existência ou não do uso de cinto de segurança nos ônibus;

- Verificou-se um padrão de localização dos ferimentos nas regiões dos corpos dos passageiros, sendo que em primeiro lugar foram os membros superiores, em segundo lugar a cabeça e a face, seguidas de pescoço, tórax, membros inferiores e região pélvica. Conseqüentemente, as lesões que mais ocorreram foram lesões superficiais, seguidas de fraturas;

- Com relação ao padrão das lesões ocorridas em decorrência do tipo de acidente, em colisões traseiras, verificou-se um grande número de lesões no pescoço, enquanto que lesões nos membros inferiores foram as mais comuns em acidentes ocorridos no embarque e desembarque de passageiros; e,

- No padrão verificado com relação ao sexo e à idade, a grande maioria das pessoas que sofreram lesões sérias ou morreram no momento do acidente foram mulheres acima de 60 anos. Isto pode ser explicado pelo fato de as mulheres realizarem um maior número 
de viagens urbanas, além do fato de que pessoas acima de 60 anos apresentaram uma menor tolerância a traumas.

Em Af. Wåhlberg (2002), procurou-se coletar as características comuns dos acidentes envolvendo o transporte público coletivo por ônibus ocorridos entre Junho de 1986 à Junho de 2000 na cidade de Upsala, Suécia. Para tanto, utilizaram-se relatórios da Companhia de Ônibus da cidade e, para classificá-los, construiu-se uma taxionomia para estes acidentes, criando-se as seguintes categorias: $i$ ) acidentes ocorridos em pontos de parada; ii) acidentes ocorridos em contato lateral com outros veículos; iii) lesões em passageiros ocorridas no lado de fora do ônibus; $i v$ ) lesões em passageiros ocorridas no interior dos ônibus; $v$ ) acidentes ocorridos com outros veículos; e, vi) responsabilidade, sendo esta última necessária para estudar a responsabilidade pela ocorrência do acidente.

De acordo com os resultados obtidos por Af. Wåhlberg (2002), em $40 \%$ do total de acidentes que ocorreram, o motorista foi considerado responsável pela sua ocorrência, entretanto, a presença de sono não foi mencionada como a principal causa da ocorrência desses acidentes, uma vez que na área urbana da cidade de Upsala, os motoristas de ônibus realizavam paradas freqüentes, de forma a tornar a viagem menos monótona.

O tipo de colisão mais freqüente foi a colisão traseira, notadamente envolvendo ônibus-ônibus em pontos de parada. Algumas razões para tal ocorrência seriam a falta de instrução dos motoristas que paravam muito próximos uns dos outros e a necessidade de manutenção das vias, principalmente nos pontos de parada durante os dias de inverno, época que apresentava acúmulo de neve sobre o pavimento, dificultando a aderência entre este e o pneu. Além da colisão traseira, a colisão lateral também apresentou grande ocorrência em pontos de parada, uma vez que estes locais apresentaram pouco espaço para a acomodação dos ônibus que chegavam simultaneamente; além disso, houve um grande número de colisões 
laterais com carros estacionados próximos aos pontos de parada, evidenciando a necessidade de um melhor planejamento nesses pontos da cidade.

Anos mais tarde, Af. Wåhlberg (2004) procurou descrever em detalhes as relações entre as várias características do envolvimento dos acidentes e investigar se era possível, ou ao menos desejável, reduzir de várias para algumas as características dos acidentes. Para tanto, a pesquisa foi realizada no mesmo local e no mesmo período já citado, diferindo da pesquisa anterior somente com relação ao número de rotas em operação.

\section{Como conclusões, obtiveram-se:}

- Estudos de acidentes envolvendo veículos grandes são mais incomuns do que aqueles que envolvem veículos pequenos;

- Não é possível encontrar qualquer estudo ou discussão a cerca da similaridade e diferença entre os acidentes com carros e com veículos grandes, uma vez que o comportamento dos motoristas de acordo com o tipo de veículo é diferente e a freqüência e as características dos acidentes envolvendo cada um dos dois tipos de veículo são diferentes;

- A possibilidade de aplicar medidas para a redução da ocorrência de acidentes é maior em companhias do que em motoristas particulares; e,

- O número total de acidentes pode não ser uma boa medida de análise, pois algumas ações pontuais podem influenciar diretamente a frequiência da ocorrência de alguns acidentes, muitas vezes não alterando o número total destes. 
Como solução para sanar os problemas verificados anteriormente, Af. Wåhlberg (2004) concluiu que seria viável: i) a re-locação dos pontos de ônibus para vias nas quais somente o tráfego de ônibus fosse permitido não existindo, portanto o estacionamento de carros próximos aos pontos de parada; e, ii) realização de treinamentos com os motoristas de ônibus, conscientizando-os a deixar uma distância de segurança em relação ao ônibus à sua frente.

Com relação a esta última questão, ressalta-se que foram constatados que cerca da metade de todos os acidentes ocorridos foram causados devido aos conflitos entre os próprios motoristas de ônibus, ou seja, devido ao comportamento dos motoristas, freqüentemente nos pontos de parada.

Outros autores como Brenac e Clabaux (2005), em uma região próxima ao subúrbio de Paris, descreveram as diferentes formas de envolvimento indireto de ônibus em acidentes de trânsito, não considerando a influência indireta da infra-estrutura no sistema de transporte público. Para a realização desse estudo, identificaram a presença da palavra "ônibus" ou qualquer sinônimo nos relatórios policias (disponibilizados em meio digital) sobre a ocorrência dos acidentes e em seguida analisaram em detalhes o acidente ocorrido. Como conclusões obtiveram-se:

- Em aproximadamente metade dos casos dos acidentes de trânsito registrados, o envolvimento indireto dos ônibus corresponderam a obstruções da visibilidade dos pedestres, ou seja, os ônibus dificultavam que o pedestre visualizasse o fluxo de tráfego para iniciar a travessia da via, provocando o acidente; 
- Grande parte destes acidentes não ocorria nas proximidades dos pontos de parada, mas sim nas proximidades da interseção, devido às conversões preferenciais à direita da via ou devido às condições de tráfego; e,

- O envolvimento indireto dos ônibus em acidentes de trânsito, também foi verificado em situações nas quais o usuário do sistema de transporte coletivo estando do lado oposto ao fluxo do ônibus e visualizando a aproximação deste, iniciava a travessia da via sem a devida precaução, causando o acidente;

Em estudo desenvolvido por Mon - Ma (2005) no qual utilizaram-se redes neurais artificiais para analisar a importância das variáveis intervenientes nos acidentes de trânsito nas interseções urbanas da cidade de São Carlos, verificou-se que veículos mais pesados, tais como ônibus, estão mais propensos a colidirem lateralmente com automóveis, devido provavelmente a duas situações:

- Má localização do ponto de parada, muito próximo do início ou fím da interseção, ocasionando que o motorista do outro veículo, por estar com a atenção nos movimentos que ocorrem na interseção, não observa o momento em que os ônibus retornam para a faixa de rolamento; e,

- Atenção desviada do motorista do ônibus, pois ao prestar atenção para o fluxo da via principal, esquece de verificar o fluxo da via em que está, colidindo lateralmente em outro veículo.

Em virtude do exposto, a análise da acidentalidade no transporte coletivo da cidade de São Carlos torna-se importante, pois contribuirá para diagnosticar a situação da segurança viária existente, além de contribuir para a redução dos custos associados aos acidentes, menor 
interrupção na operação das linhas de transporte coletivo, maior qualidade do serviço de transporte coletivo prestado, dentre outros fatores.

\subsection{SISTEMA DE INFORMAÇÕES GEOGRÁFICAS (SIG)}

\subsubsection{Introdução}

O surgimento do primeiro Sistema de Informações Geográficas (SIG) data da década de 60, no Canadá, no qual as agências governamentais ligadas ao meio ambiente já apresentavam dois objetivos traçados: $i$ ) mapear suas reservas naturais; e, ii) realizar várias análises sobre seu meio ambiente, a partir do processamento de uma grande quantidade de dados criados pelo inventário de terras canadenses (CALIJURI \& RÖHM, 1994).

De acordo com Câmara et al (1996), na década de 70 surgiu a topologia aplicada, a partir de fundamentos matemáticos voltados para a cartografia, a qual possibilitou a realização de análises espaciais entre dados cartográficos. Na década de 80 , com a popularização e o barateamento das estações de trabalho, computadores pessoais e banco de dados, difundiu-se o uso de SIG, incorporando-se muitas funções de análise espacial, sendo que atualmente é amplamente utilizado em diversos campos que necessitam de visualização espacial dos dados utilizados.

\subsubsection{Definições e características}

De acordo com Congalton e Green (1992), “um SIG pode ser definido como um sistema para entrada, armazenamento, manipulação, análise e exibição de dados geograficamente referenciados.” 
Para Huxhold e Levinsohn² (1995, apud MANTOVANI, 2003, p. 62) e Kennedy (1996), o SIG, pode ser definido como um sistema composto por um banco de dados e por um conjunto de recursos tecnológicos (hardware e software), os quais contém dados e procedimentos para coletar, armazenar, manipular, gerenciar, atualizar, analisar e apresentar mapas e informações descritivas que podem ser referenciadas geograficamente, auxiliando dessa forma na resolução de problemas complexos de planejamento e gerenciamento. Além dos recursos tecnológicos já citados, também há o recurso humano, fundamental para sua operacionalização e funcionamento.

Segundo Antenucci et $\mathrm{al}^{3}$ (1991), um SIG possibilita: i) coletar, armazenar e restabelecer informações baseadas em suas localizações espaciais; ii) identificar locais dentro do ambiente de modo a selecionar critérios específicos; iii) explorar relacionamentos entre dados; $i v$ ) analisar e relacionar dados espacialmente, como auxílio à tomada de decisões; $v$ ) facilitar a seleção e transposição de dados para modelos específicos de aplicação analítica, capazes de acessar o impacto de alternativas selecionadas; vi) mostrar um ambiente selecionado, gráfica e numericamente, antes ou depois de análises.

De acordo com Sanches (2000), o armazenamento de informações em um SIG é realizado por meio de camadas temáticas (layers), que são ligadas graficamente através de suas coordenadas, conforme pode ser visto na Figura 2.4.

\footnotetext{
${ }^{2}$ HUXHOLD, W. E.; LEVINSOHN, A. G. Managing Geographic Information System Projects. USA, NY, Oxford: Oxford University Press Inc., 1995. 247p.

3 ANTENUCCI, J. C.; BROWN, K.; CROSWELL, P. L.; KEVANY, M. J.; ARCHER, H. Geographic Information Systems: A Guide to the Technology. USA, NY, New York: Chapman \& Hall, 1991, 301p.
} 


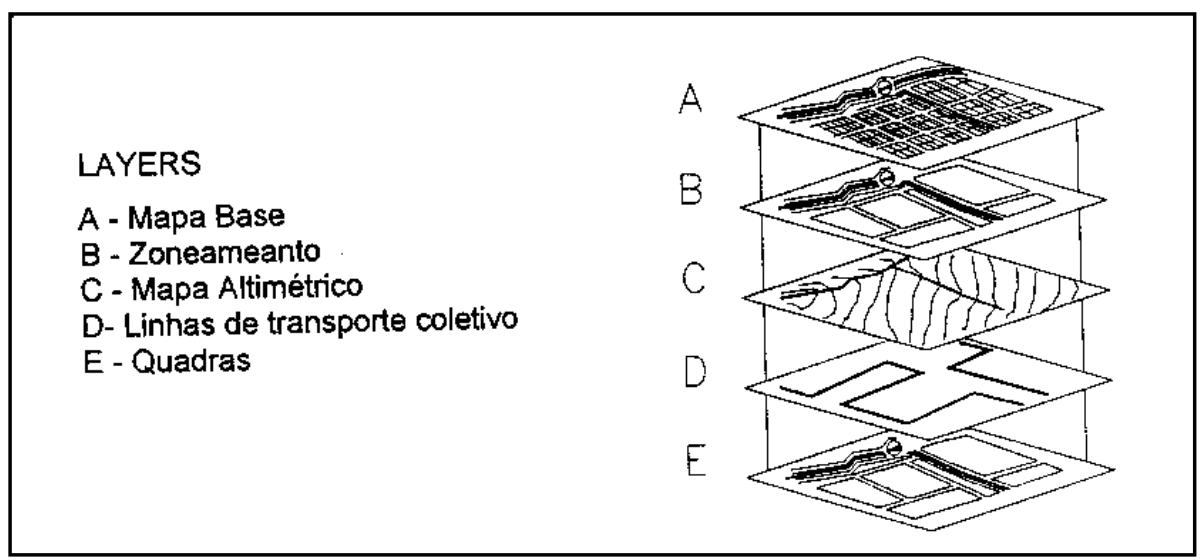

Figura 2.4: Layers de um SIG.

Fonte: Sanches, S. P. (2000).

Para Calijuri e Röhm (1994), com relação ao funcionamento, os SIGs apresentam o banco de dados como sendo a sua espinha dorsal e, em segundo lugar o gerenciador de banco de dados, que tem a função de garantir que as informações estejam disponíveis de forma consistente e que sejam acessadas com a eficiência exigida pelas aplicações. Este banco de dados (espinha dorsal) é composto por dados espaciais (dados geográficos), os quais descrevem as características da superfície do terreno, tais como forma e posição e, por um banco de dados de atributos (dados alfanuméricos), os quais descrevem a qualidade destas características.

Os dados espaciais, ou geográficos, podem ser estruturados de duas formas: estrutura matricial e estrutura vetorial:

- Estrutura Matricial: consiste na divisão do espaço em uma malha regular de resolução específica, formando uma matriz de pequenos pontos ou células, sendo que a cada um deles são associadas informações alfanuméricas ou atributos. Ao se discretizar a informação contida nos pontos ou nas células, ela (informação) perde exatidão e detalhes, porém ganha facilidade de manipulação no ambiente computacional. Além disso, apresenta grande integração com imagens de sensoriamento remoto, uma vez que ambos utilizam a estrutura matricial; e, 
- Estrutura Vetorial: considera o espaço de forma contínua, tentando reproduzir as dimensões e formas da maneira mais fiel possível, considerando que todos os pontos no espaço têm coordenadas exatas, garantindo assim um grau de precisão maior para os programas de estrutura vetorial. Porém, apresenta menor eficiência em oferecer operações algébricas, bem como sobreposições de mapas.

De acordo com Renúncio (1995), os benefícios da incorporação da tecnologia SIG, dentre muitos, são: i) eliminam-se informações redundantes e problemas advindos da manutenção de múltiplos conjuntos de dados; ii) as revisões de mapas são mais fáceis e rápidas; iii) a mão-de-obra torna-se mais produtiva; $i v$ ) manutenção do banco de dados em tempo real, entre outros.

Diante dos benefícios citados, pode-se concluir que os SIGs são de fundamental importância em muitas áreas, notadamente na área de transportes, na qual o volume de informações a serem processadas é muito grande. Nesta área destaca-se dentre outros SIGs, o Sistema de Informações Geográficas para Transportes (SIG-T), que nada mais é do que um SIG adaptado.

\subsubsection{Sistema de Informações Geográficas para Transportes (SIG-T)}

Os SIG-Ts são Sistemas de Informação Geográfica para Transportes e constituem-se em SIGs adaptados com ferramentas específicas, auxiliando na resolução de problemas de planejamento de transportes.

De acordo com Cardoso (1999), a intensificação do uso de Sistemas de Informação Geográfica em Transportes (SIG-T) ocorreu principalmente nos últimos anos da década de 80 e notadamente nos anos 90, tratando-se portanto de um sistema de desenvolvimento relativamente recente que ainda possui muitos aspectos a serem consolidados e melhorados. 
Para Antenucci et $\mathrm{al}^{4}$ (1991, apud MANTOVANI, 2003, p. 65), os SIG-Ts podem ser utilizados tanto nos setores públicos, através dos planejadores e gestores municipais, estaduais e federais, como também nos setores privados, por indústrias ou empresas de serviços que empreguem logística de transporte de carga ou passageiros.

De acordo com Viviani et al (1994), os SIG-T’s possuem muitas aplicações, dentre as quais citam-se: $i$ ) projeto geométrico de vias; ii) projeto de terraplenagem; iii) monitoramento e controle de tráfego; $i v$ ) oferta e demanda de transportes; v) prevenção de acidentes; vi) otimização de rotas; vii) monitoramento e controle de operações rodoviárias; viii) monitoramento de unidades móveis, dentre outras.

Entre as funções do SIG-T, destacam-se: modelagem, manipulação e análise de dados, as quais não são completamente preenchidas pelo SIG tradicional (THILL, 2000). Dentre os SIG-Ts existentes, citam-se os softwares TransCAD e UFOSNET.

\subsubsection{TransCAD}

O Trans $C A D^{5}$ é um Sistema de Informações Geográficas aplicado aos problemas de transporte (SIG-T). Devido às suas possibilidades serem amplas, tanto na visualização e localização dos dados quanto no agrupamento, na seleção de informações estatísticas, correlação entre as variáveis e cálculo destes dados, o TransCAD torna-se uma ferramenta importante na análise dos dados de acidentes de trânsito. Entre seus recursos, citam-se a criação de mapas temáticos e uma rápida atualização do banco de dados, além de permitir o intercâmbio com outros programas (MANTOVANI, 2003).

\footnotetext{
${ }^{4}$ ANTENUCCI, J. C.; BROWN, K.; CROSWELL, P. L.; KEVANY, M. J.; ARCHER, H. Geographic Information Systems: A Guide to the Technology. USA, NY, New York: Chapman \& Hall, 1991, 301p.

5 Desenvolvido por Caliper Corporation
} 
O programa permite estabelecer uma integração dos dados gráficos contidos no mapa digitalizado da cidade com o banco de dados dos acidentes, facilitando desta forma as análises e visualizações dos mesmos. Pode-se também, através do programa, criar mapas temáticos, por meio do agrupamento de dados de um item selecionado ou mediante condições predeterminadas.

Cada item do banco de dados de acidentes fornece um resumo estatístico dos mesmos. Permite-se analisar as áreas, vias e pontos críticos por meio de agrupamentos dos dados dos acidentes, formando um conjunto de pontos posicionados geograficamente na rede viária urbana, em áreas do mapa da cidade.

A partir do conhecimento destes locais críticos, deve-se submetê-los a tratamentos da engenharia de tráfego que se constitui no estabelecimento de critérios para a classificação dos mesmos, identificação dos padrões de acidentes que possam ocorrer devido à geometria, sinalização e regulamentação da via e implantação de medidas corretivas para a redução dos acidentes.

Dentre os autores que utilizaram o TransCAD para obtenção de resultados em suas pesquisas, citam-se Simões (2001) que utilizou esta ferramenta na proposta de implantação de um sistema de gestão da segurança no trânsito urbano, Mantovani (2003), obteve resultados satisfatórios com o TransCAD em sua proposta de implementação de um sistema integrado de gestão em segurança de tráfego, enquanto que Santos (2006), agregou o TransCAD à ferramentas de estatística espacial, para analisar os acidentes de trânsito ocorridos na cidade de São Carlos, obtendo resultados satisfatórios. 


\section{3}

\section{METODOLOGIA EMPREGADA}

Para a consolidação deste trabalho, foi necessária a realização das várias etapas presentes na Figura 3.1.

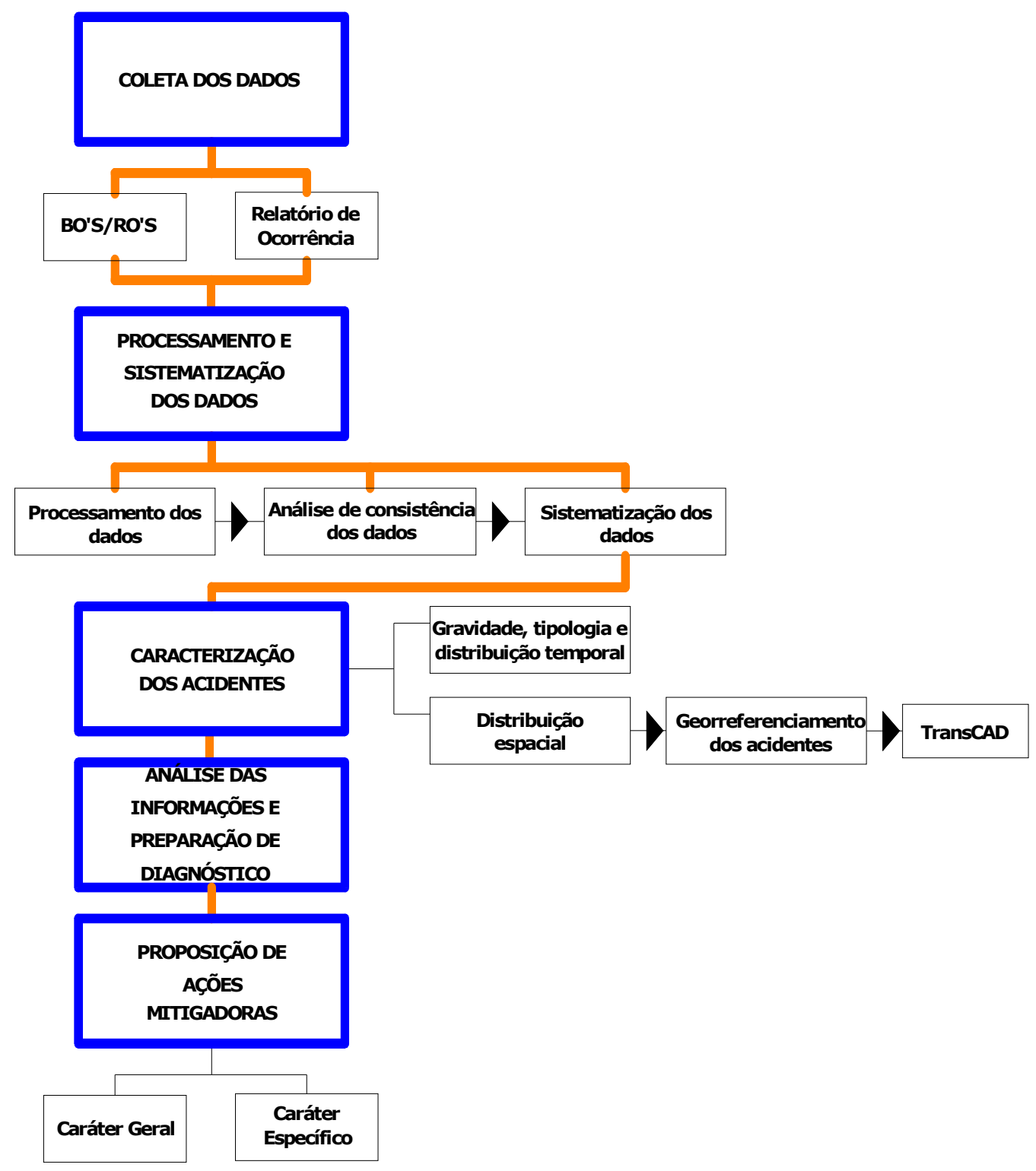

Figura 3.1: Estrutura do método do trabalho.

Para melhor compreensão, cada etapa será detalhada a seguir. 


\subsection{COLETA DOS DADOS}

As informações sobre acidentes de trânsito são registradas pela Polícia Militar ou Civil em Boletins de Ocorrência ou Registros de Ocorrências, de acordo com o caso. Após a execução do $\mathrm{BO} / \mathrm{RO}$, as partes envolvidas, sejam elas pessoas físicas ou jurídicas, podem adquirir uma cópia do mesmo para eventuais procedimentos jurídicos que se fizerem necessários.

Na cidade de São Carlos, por determinação do órgão gestor, a empresa operadora é obrigada a possuir a relação de todos os registros de acidentes envolvendo os ônibus de transporte coletivo. Tal medida também favorece procedimentos internos de identificação dos motoristas envolvidos em acidentes de trânsito para posterior aplicação de penalidade.

Em virtude disto, a empresa operadora do transporte coletivo da cidade de São Carlos possui um banco de dados manual contendo todos os BO'S/RO'S que envolveram os veículos de transporte coletivo ao longo do período de operação.

De acordo com Gold (1998), para a criação de um banco de dados manual de acidentes de trânsito é necessário apenas a anotação organizada dos dados presentes nos BO'S/RO'S ou uma fotocópia dos mesmos. Em determinados casos, a utilização de uma ficha-resumo e de um croqui complementar para referência contendo informações sobre o local do acidente e as características do acidente são suficientes para a análise e diagnóstico de acidentes em pontos críticos.

Através de uma cláusula presente no contrato de prestação de serviço entre a empresa operadora do sistema de transporte coletivo da cidade de São Carlos e o órgão gestor, a empresa é obrigada a enviar mensalmente à Prefeitura Municipal de São Carlos (PMSC), 
todas as cópias de BO'S/RO’S que envolveram os veículos de transporte coletivo referente ao mês anterior.

Após consulta e autorização do órgão gestor, foram obtidas as cópias dos BO’S/RO'S e procedeu-se à coleta dos dados referentes aos acidentes de trânsito envolvendo o transporte coletivo nos anos de 2005 e 2006.

Juntamente com o $\mathrm{BO} / \mathrm{RO}$ se obteve um formulário desenvolvido e utilizado pela empresa operadora, denominado "Relatório de Ocorrência", o qual apresenta campos que contém as informações sobre o acidente envolvendo o veículo de transporte coletivo e é preenchido manualmente por um fiscal da própria empresa, imediatamente após a ocorrência do acidente. Em anexo encontra-se um modelo do "Relatório de Ocorrência".

No "Relatório de Ocorrência" são listados os seguintes campos relativos aos acidentes de trânsito envolvendo os veículos de transporte coletivo:

- Localização temporal do acidente: data e hora do ocorrido;

- Dados do veículo de transporte coletivo e dos operadores: prefixo e placa do veículo, nome e número de registro dos operadores envolvidos;

- Dados do outro veículo envolvido: marca, ano, placa, município de emplacamento, unidade da federação, proprietário, fone, endereço, bairro, cidade, vigência ou não de seguro e especificação e dados do condutor;

- Dados policiais: número da viatura, horário de liberação do veículo, nome dos policiais e perito envolvidos, número dos BO'S preenchidos, realização ou não de perícia, diagrama para indicação dos pontos amassados em veículos de passeio, ônibus de transporte coletivo e caminhões, caracterização e croqui do local do acidente; 
- Descrição da ocorrência: descrição da situação antes, durante (acidente em si) e depois do acidente, realizada por fiscal da empresa operadora;

- Danos materiais: descrição dos danos materiais causados no veículo de transporte coletivo e no outro veículo envolvido;

- Análise dos fatos: fiscal da empresa indica se o condutor do ônibus foi ou não o causador do acidente, embasando a indicação com um breve parecer;

- Testemunhas: nome e endereço das testemunhas envolvidas no acidente; e,

- Pessoas acidentadas: nome, endereço da vítima e descrição do ferimento sofrido pela mesma.

Este relatório, além de possibilitar à empresa controlar a quantidade e os tipos de veículos envolvidos em acidentes de trânsito, propicia identificar o motivo de ocorrência dos acidentes e os condutores que mais se envolvem em acidentes, para posteriormente implementar medidas com o objetivo de reduzir o número de ocorrência desses acidentes.

\subsection{PROCESSAMENTO E SISTEMATIZAÇÃO DOS DADOS}

\subsubsection{Processamento dos dados}

Após a coleta dos dados de acidentes de trânsito envolvendo o transporte coletivo, procedeu-se ao processamento destes dados, através de sua inserção no Banco de Dados de Acidentes de Trânsito (BDAT) da cidade de São Carlos. 
Este banco de dados foi elaborado por Raia Jr. (2004) em uma parceria com a Prefeitura Municipal de São Carlos (PMSC), baseando-se nos dados de BO'S preenchidos e disponibilizados pela Polícia Militar, utilizando plataforma Access para sua operacionalização. No banco de dados é possível inserir todas as informações contidas nos BO'S/RO'S, com exceção do campo destinado ao croqui, uma vez que a plataforma operacional não permite tal tarefa. Na Figura 3.2 é mostrada a tela de apresentação do BDAT. As demais telas do banco de dados que foram utilizadas para o processamento e sistematização dos dados de acidentes de trânsito encontram-se em anexo.

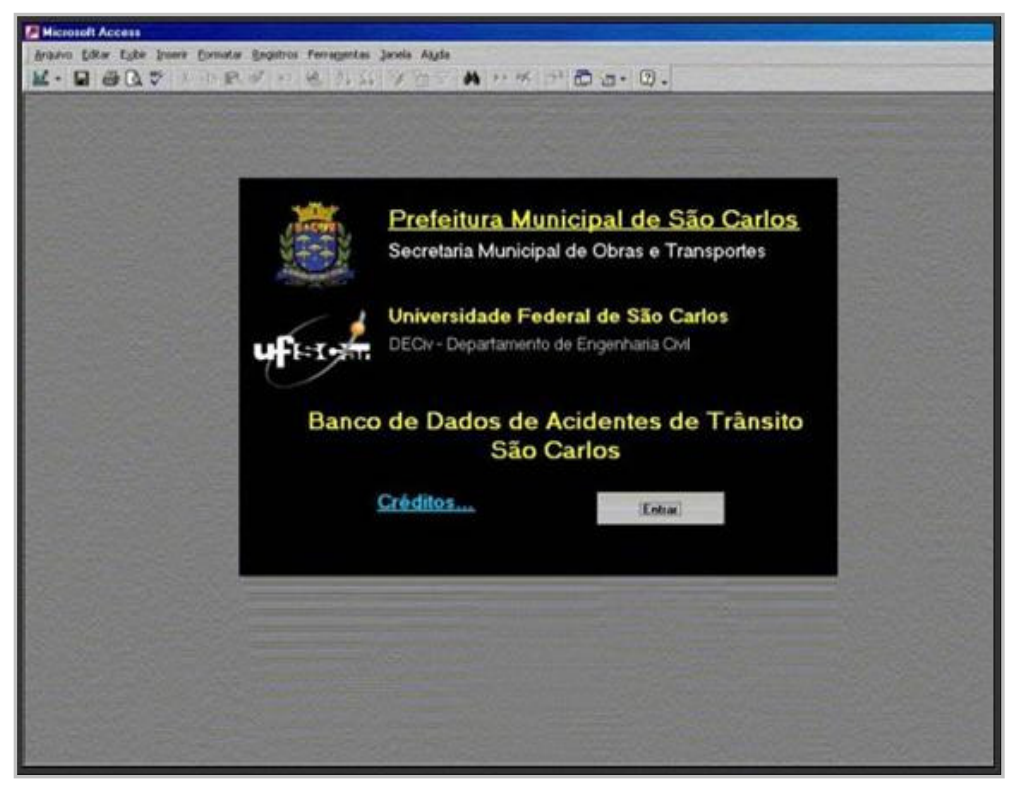

Figura 3.2: Tela de apresentação do BDAT

Após consulta e autorização da Secretaria Municipal de Transporte, Trânsito e Vias Públicas (SMTTVP) para a utilização do banco de dados, efetuou-se a inserção dos dados relativos aos acidentes de trânsito envolvendo o transporte coletivo. Este banco é provido do "Menu de Controle" no qual é possível editar o nome das ruas contidas nos registros de acidentes e consultar, inserir e editar os dados de acidentes de trânsito ocorridos entre os anos 2000 e 2015. 
Após a escolha do ano e da opção "Inserir", iniciou-se o preenchimento do "Formulário do BO". Neste formulário, todas as informações contidas nos registros de ocorrência foram inseridas, além da possibilidade de acrescentar informações adicionais no campo “Obs.”. Entretanto, este campo se apresentou limitado a um determinado número de caracteres, sendo que em alguns casos não foi possível inserir todas as observações pertinentes ao acidente, inclusive aquelas relatadas no "Relatório de Ocorrência".

\subsubsection{Análise de consistência dos dados}

Antes de proceder à sistematização dos dados de acidentes de trânsito, foi realizada uma análise de consistência dos mesmos com o objetivo de verificar possíveis incoerências nos registros de acidentes, tais como ausência de vítimas em acidentes que resultaram em vítimas, horário de ocorrência do acidente em desacordo com o horário de operação do sistema de transporte coletivo, localização da ocorrência dos acidentes, etc.

Com relação à localização do acidente, o mesmo poderia ocorrer ao longo da via ou no cruzamento de duas ou mais vias. De maneira a evitar possíveis equívocos de localização e conseqüentes erros de análise, foram verificados alguns critérios relacionados às vias envolvidas:

a) Identificar e corrigir dados de acidentes que apresentaram nomes das vias envolvidas escritos de forma diferente, ou seja, para uma mesma via, duas ou mais grafias diferentes;

b) Verificar a exata localização das vias envolvidas, de maneira a evitar que vias paralelas estivessem envolvidas em acidentes ocorridos em cruzamentos e vias transversais em acidentes ocorridos ao longo das vias; 
c) Identificar e tratar os registros de acidentes que não permitiam a completa localização dos mesmos;

d) Identificar e excluir os acidentes de transporte coletivo que ocorreram fora da mancha urbana da cidade de São Carlos, tal como nos distritos de Água Vermelha e Santa Eudóxia, bem como aqueles que ocorreram nas rodovias, uma vez que neste estudo pretendese estudar somente os acidentes ocorridos dentro da área urbana cidade.

Durante a análise de consistência dos dados referente à localização do acidente, foi verificado que alguns registros de acidentes de trânsito não possuíam todos os campos do BDAT preenchidos (Rua 1, Rua 2, Referência e Número). Entretanto, se, por exemplo, o campo "Referência" não estivesse preenchido, mas sim o campo "Número", este último completava a informação sobre a localização do acidente e vice-versa. Sendo assim, após a realização de análise de consistência dos dados, foi possível classificar como válidos todos os registros de acidentes de trânsito.

\subsubsection{Sistematização dos dados}

Em prosseguimento à análise de consistência dos dados, iniciou-se a sistematização dos mesmos, através da construção de tabelas e gráficos.

Para a execução desta tarefa, através do campo "Consultar" presente no "Menu de Controle" foi possível selecionar e quantificar todas as características dos acidentes de trânsito, tais como, gravidade, tipo, dia da semana, mês do ano, intervalo horário, período do dia (diurno e noturno), condições meteorológicas e local de ocorrência. Para tanto, foi necessário ativar vários sub-campos, a saber: i) período do dia; ii) dia da semana; iii) horário; iv) local (todos, ao longo e cruzamento); v) tipo de veículo; vi) sexo; vii) idade; viii) tipo de acidente; ix) iluminação; e, $x$ ) gravidade. 
Especificamente com relação à característica "condição meteorológica", diante da impossibilidade de levantamento desta informação no BDAT, exportou-se todas as informações sobre acidentes de trânsito presente no software Access para o software Excel, através da criação de planilha eletrônica

Com o objetivo de organizar todas as características dos acidentes obtidas do BDAT e permitir melhor visualização dos resultados, foi utilizado o software Excel para a construção de tabelas e gráficos. Escolheu-se este software para realizar o tratamento dos dados, devido à disponibilidade, facilidade e conhecimento do mesmo pela pesquisadora, além do software possibilitar a ilustração dos resultados em uma forma gráfica e de fácil compreensão.

\subsection{CARACTERIZAÇÃO DOS ACIDENTES}

Neste estudo, a caracterização dos acidentes consistiu em organizar todas as características em tabelas e gráficos de tal forma que fosse possível obter um panorama da acidentalidade envolvendo os veículos de transporte coletivo. Esta caracterização foi realizada utilizando-se o software Excel, devido às vantagens descritas anteriormente.

Para a execução da distribuição espacial dos acidentes de trânsito, utilizou-se o software TransCAD 3.6 (Academic), contendo a base cartográfica do município de São Carlos - SP, disponibilizado pelo Departamento de Transportes da Escola de Engenharia de São Carlos (STT - EESC).

Após a etapa de análise de consistência dos dados referente à localização do acidente, verificou-se que os mesmos ocorreram em interseções ou ao longo das vias. De posse destas informações criou-se um banco de dados de pontos em ambiente SIG no qual, a cada acidente 
locado, o mesmo era inserido no referido banco, obtendo-se como produto final o banco de dados de pontos.

Para o exato georreferenciamento dos acidentes ocorridos ao longo das vias, de posse do nome da via e do numeral da edificação mais próxima do local do acidente, utilizou-se o site denominado "Google Maps" disponível na Internet no sítio www.maps.google.com, o qual forneceu a localização mais próxima dos pontos no mapa da cidade. Ressalta-se que o Banco de Dados do "Google Maps”, por estar condicionado ao fator humano, também pode conter erros de localização.

No banco de dados de pontos também foi possível associar a cada acidente os atributos referentes ao: $i$ ) número total de acidentes; ii) número total de acidentes que resultaram em danos materiais; iii) número total de acidentes que resultaram em vítimas não fatais; e, iv) número total de acidentes que resultaram em vítimas fatais.

De posse de tais atributos, procedeu-se à geração de mapas temáticos que permitiram melhor visualização e análise da distribuição espacial dos acidentes de trânsito envolvendo os ônibus de transporte coletivo.

\subsection{ANÁLISE DAS INFORMAÇÕES E PREPARAÇÃO DE DIAGNÓSTICO}

Após a caracterização dos acidentes de trânsito envolvendo o transporte coletivo, as informações obtidas foram analisadas com base nos fundamentos sobre segurança do trânsito apresentados no capítulo denominado "Revisão Bibliográfica" e na observação criteriosa das particularidades da cidade de São Carlos e das condições operacionais do Sistema de Transporte Coletivo. 
Analisadas as informações, um diagnóstico sobre a situação foi elaborado, com o objetivo de identificar as principais características dos acidentes de trânsito envolvendo o transporte coletivo, tais como: $i$ ) principais tipos de acidentes envolvendo o ônibus de transporte coletivo e suas prováveis causas; ii) distribuição temporal dos acidentes; iii) identificação dos tipos de acidentes ocorridos de acordo com o período do dia; $i v$ ) distribuição espacial dos acidente de acordo com a gravidade e com a localização.

Após a realização da análise das informações e da preparação de um diagnóstico sobre a acidentalidade do transporte coletivo na cidade de São Carlos, procedeu-se à elaboração de ações mitigadoras para a redução dos acidentes de trânsito.

\subsection{PROPOSIÇÃO DE AÇÕES MITIGADORAS}

De posse da análise das informações de acidentes de trânsito envolvendo o transporte coletivo, bem como da elaboração de um diagnóstico sobre a situação vigente, foram propostas ações mitigadoras em dois níveis com o objetivo de obter um ganho na segurança viária.

No primeiro nível foram propostas ações mitigadoras de caráter geral que poderão ser implementadas pelo poder público (melhoria da sinalização, poda adequada de árvores, fiscalização permanente) e pela empresa operadora (treinamento da mão de obra operante, manutenções preventivas e corretivas da frota, campanhas educativas para a redução de acidentes, etc.).

No segundo nível foram elaboradas ações mitigadoras de caráter específico para cada tipo de acidente, com base na provável causa de ocorrência dos mesmos, para a principal 
interseção crítica de acidentes. Por exemplo, analisando-se os tipos de acidentes e suas prováveis causas, na interseção "A”, devido ao grande número de acidentes do tipo colisão transversal, é necessário reforçar a sinalização que se encontra apagada e realizar poda de árvore para melhorar a visibilidade. 


\section{4}

\section{CARACTERIZAÇ̃̃O DOS ACIDENTES}

\subsection{INFORMAÇÕES GERAIS}

A cidade de São Carlos situa-se na região central do estado de São Paulo, a 233 km da capital e faz divisa com os municípios de Ibaté, Itirapina, Rincão, Santa Lúcia, Analândia, Luís Antônio, Araraquara, Descalvado, Brotas, Américo Brasiliense e Ribeirão Bonito, conforme Figura 4.1.

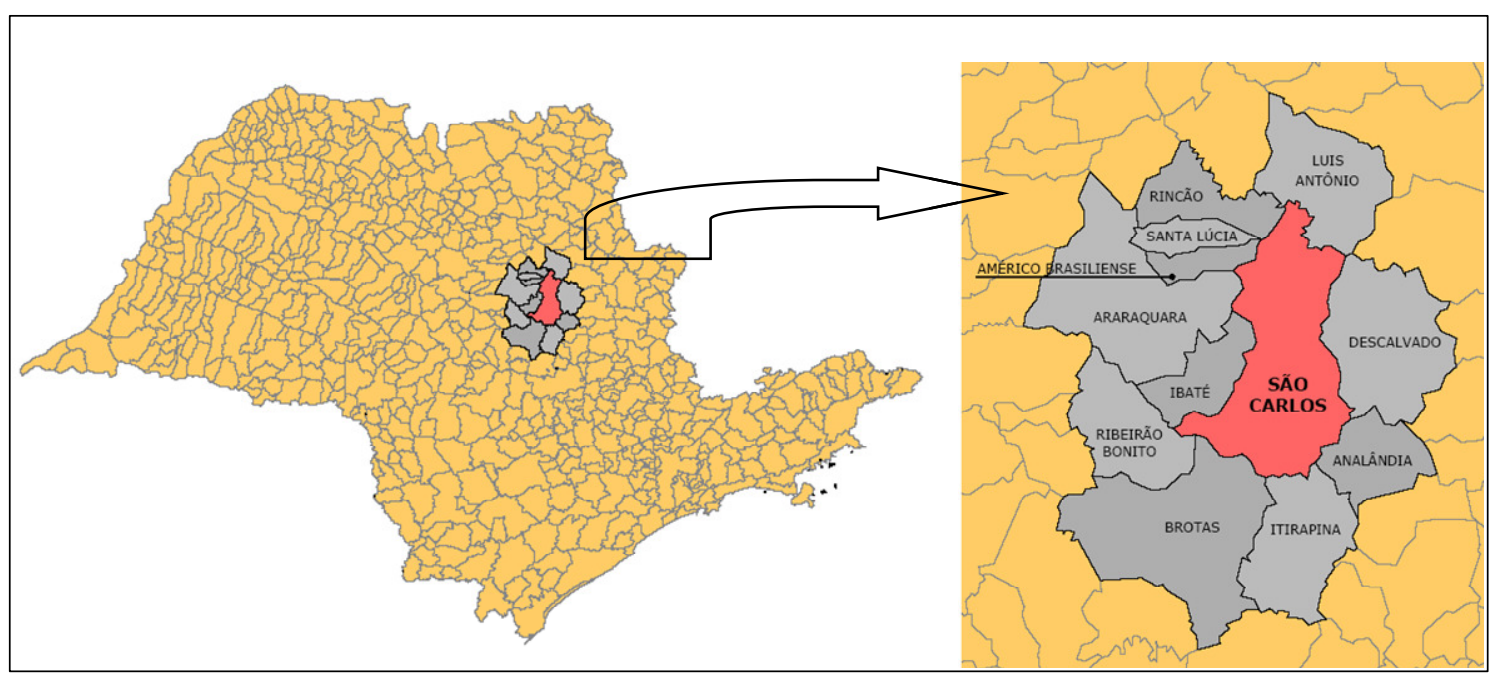

Figura 4.1: Localização da cidade de São Carlos.

Nos anos de 2005 e 2006, segundo dados do IBGE (2008) a população média foi de 218.702 para uma frota média de veículos igual a 95.503, de acordo com dados do DENATRAN (2008), resultando um índice de motorização de 43,67 veículos/100 habitantes, ou seja, 1 veículo para cada 2,29 habitantes. No mesmo período, os demais índices de acidentes correspondentes foram: 41,47 acidentes/ano/1.000 veículos e 18,11 acidentes/ano/1.000 habitantes. 
Com relação ao sistema de transporte coletivo, está estruturado em 53 linhas regulares que operam ao longo de todo o dia e 166 linhas que operam somente nos horários de pico, denominadas de linhas especiais. O sistema é essencialmente diametral com $92,45 \%$ das linhas trafegando pela região central e é baseado no sistema de integração física, temporal e tarifária, transportando diariamente 65.000 passageiros. Apresenta 37 linhas $(69,81 \%$ do total de linhas) operando com somente um ônibus e o restante, 16 linhas $(30,19 \%$ do total de linhas), com dois ônibus. Na Figura 4.2 é visualizada a rede de linhas de transporte coletivo da cidade de São Carlos. 


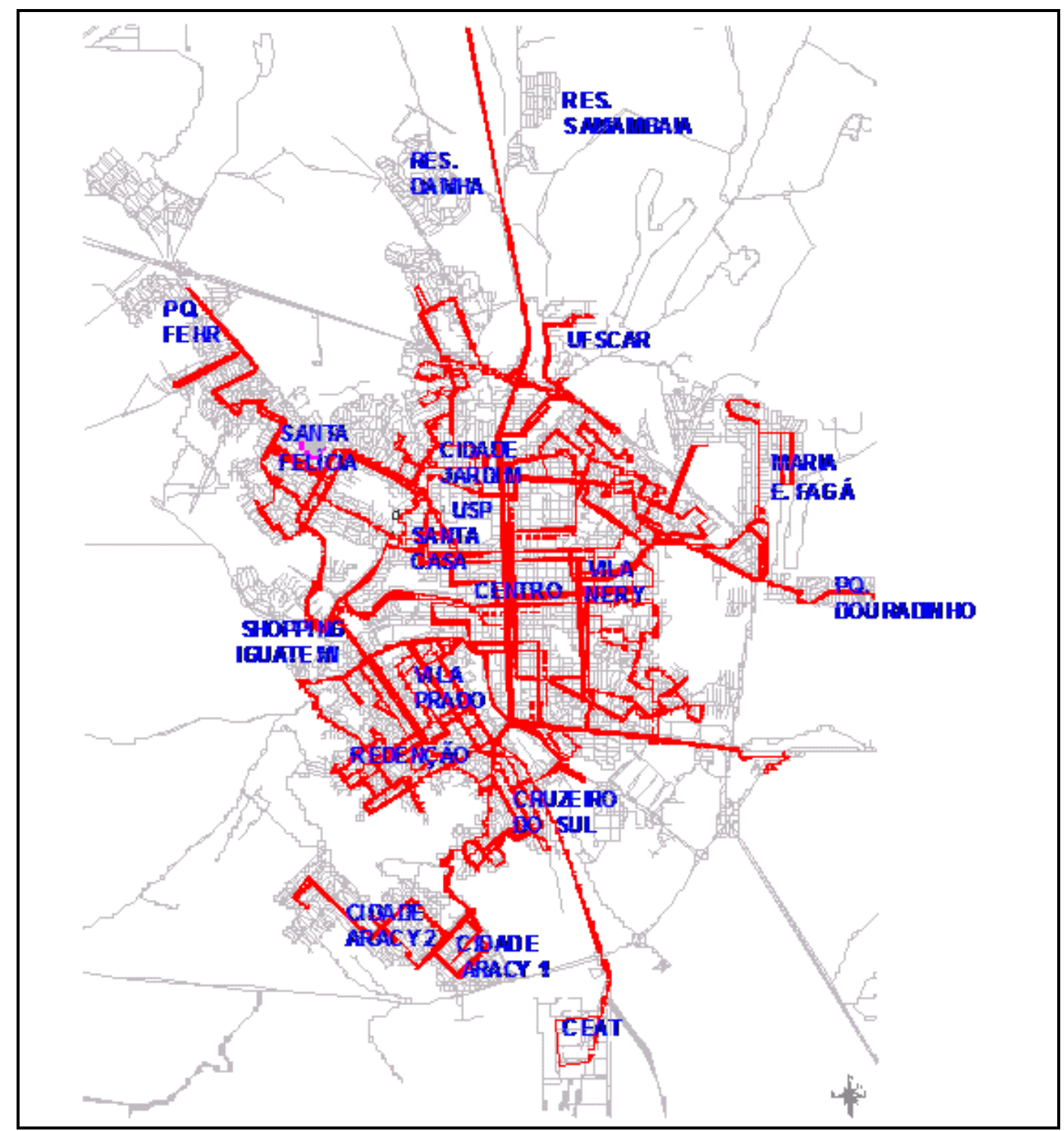

Figura 4.2: Linhas do sistema de transporte coletivo da cidade de São Carlos.

No biênio 2005 - 2006 foram registrados 7.921 acidentes de trânsito na cidade de São Carlos, sendo que 342 acidentes envolveram os ônibus de transporte público coletivo (4,32\% do total), dos quais $269(78,65 \%)$ acidentes resultaram em acidentes sem vítimas e 73 $(21,35 \%)$ com vítimas (fatais e não fatais).

Com relação aos veículos de transporte coletivo, a frota média em operação (incluindo ônibus convencional e micro-ônibus) no período foi de 97 veículos, o que significa uma média de 1.762,87 acidentes/ano/1.000 ônibus e um intervalo de 2,13 dias entre acidentes. 


\subsection{CARACTERÍSTICAS DOS ACIDENTES}

A seguir são apresentadas as principais características relativas aos acidentes de trânsito envolvendo os veículos de transporte coletivo na cidade de São Carlos para o biênio $2005-2006$.

\subsubsection{Quanto à gravidade}

Os dados relativos à gravidade dos acidentes encontram-se na Tabela 4.1 e na Figura 4.3.

Tabela 4.1: Número de acidentes de trânsito envolvendo o transporte coletivo de acordo com a gravidade.

\begin{tabular}{lcl}
\hline \multicolumn{1}{c}{ Gravidade dos Acidentes } & \multicolumn{2}{c}{ Total } \\
& Biênio $\mathbf{2 0 0 5} \mathbf{- 2 0 0 6}$ \\
\hline Sem vítimas (somente danos materiais) & 269 & $(78,65 \%)$ \\
Com vítimas (fatais e não fatais) & 73 & $(21,35 \%)$ \\
Com vítimas não fatais & 69 & $(20,18 \%)$ \\
Com vítimas fatais & 4 & $(1,17 \%)$ \\
\hline Total & $\mathbf{3 4 2}$ & $(\mathbf{1 0 0 , 0 0 \% )}$ \\
\hline
\end{tabular}




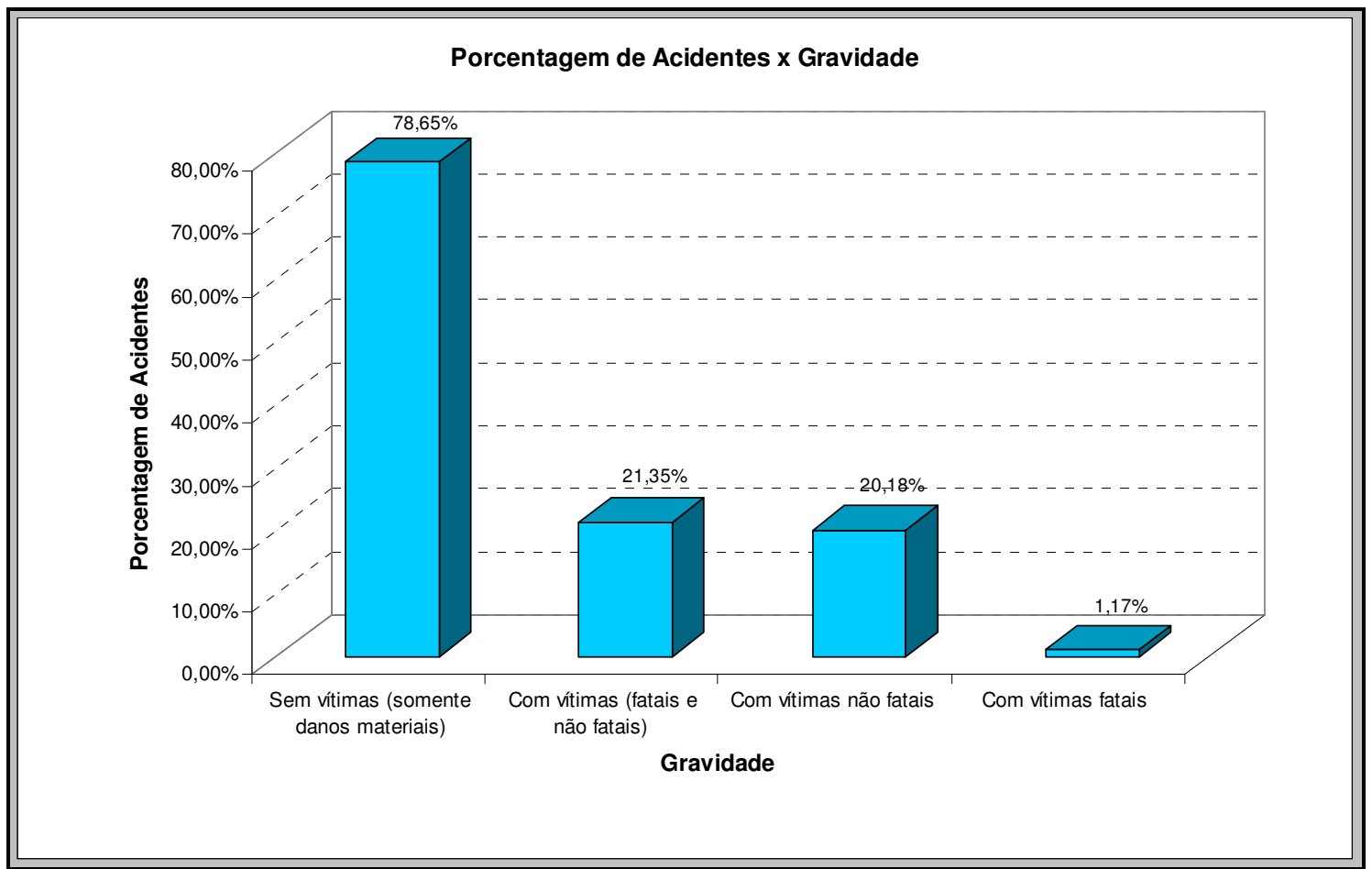

Figura 4.3: Porcentagem de acidentes de trânsito envolvendo o transporte coletivo de acordo com a gravidade.

\subsubsection{Quanto ao tipo}

Os dados referentes aos tipos de acidentes são mostrados na Tabela 4.2 e na Figura 4.4 .

Tabela 4.2: Número de acidentes de trânsito envolvendo o transporte coletivo de acordo com o tipo.

Tipo de Acidentes de Trânsito

\section{Total}

Biênio 2005 - 2006

\begin{tabular}{lcl}
\hline Colisão Transversal & 121 & $(35,38 \%)$ \\
Colisão Lateral & 92 & $(26,90 \%)$ \\
Colisão Traseira & 62 & $(18,13 \%)$ \\
Choque em veículo estacionado & 41 & $(11,99 \%)$ \\
Colisão Frontal & 11 & $(3,22 \%)$ \\
Queda de passageiro * & 10 & $(2,92 \%)$ \\
Atropelamento de pedestre & 3 & $(0,88 \%)$ \\
Choque em objeto fixo & 2 & $(0,58 \%)$ \\
\hline Total & $\mathbf{3 4 2}$ & $(\mathbf{1 0 0 , 0 0 \%})$ \\
\hline
\end{tabular}

* No interior do veículo ou em operação de embarque/desembarque. 


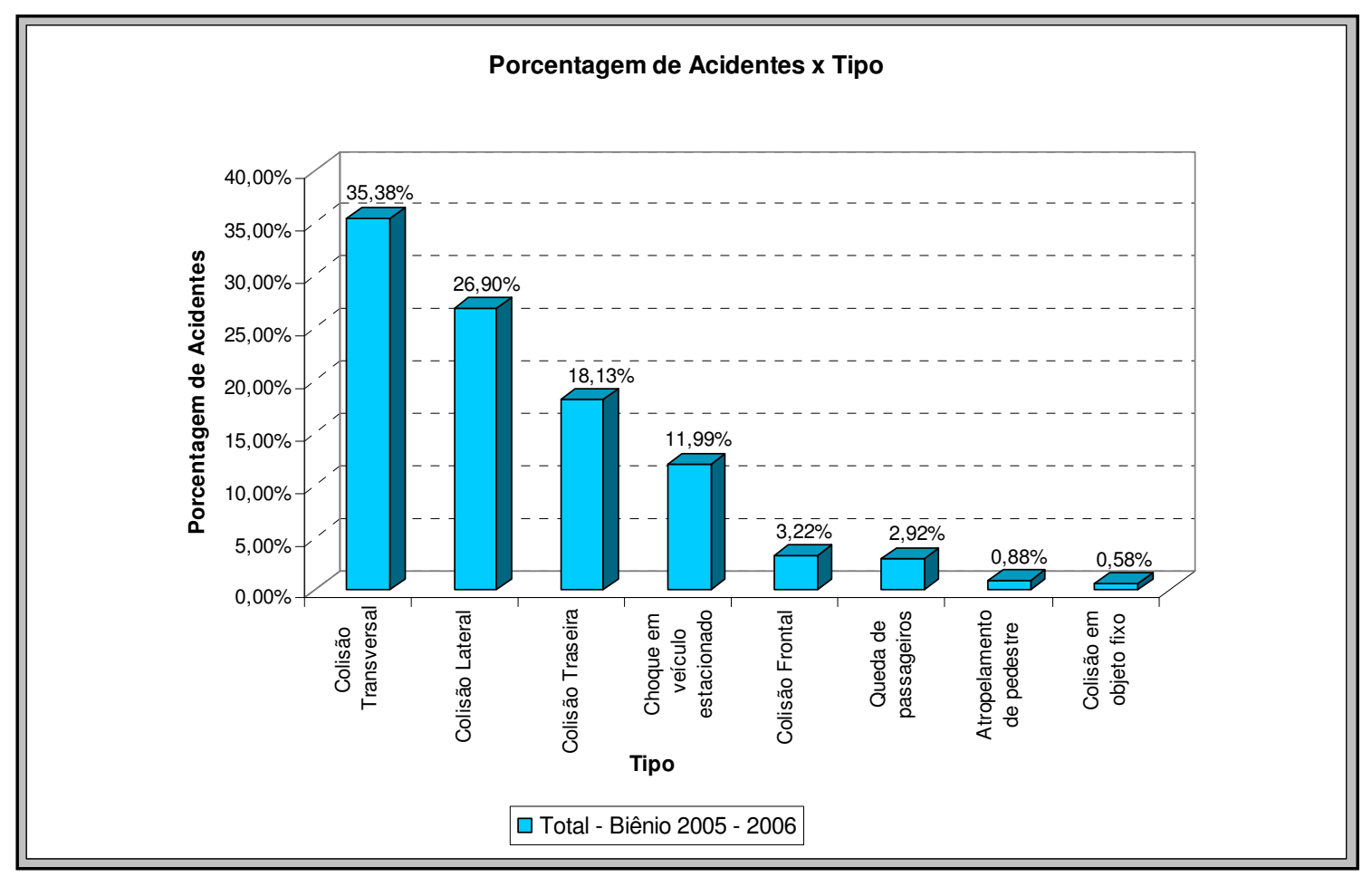

Figura 4.4: Porcentagem de acidentes de trânsito envolvendo o transporte coletivo de acordo com o tipo.

A distribuição dos tipos de acidentes considerando a gravidade é mostrada na Tabela 4.3 e na Figura 4.5. 
Tabela 4.3: Número de acidentes de trânsito envolvendo o transporte coletivo de acordo com o tipo considerando a gravidade.

\begin{tabular}{|c|c|c|c|c|c|c|c|c|}
\hline \multirow[b]{2}{*}{$\begin{array}{l}\text { Gravidade dos } \\
\text { Acidentes }\end{array}$} & \multicolumn{8}{|c|}{ Tipos de Acidentes } \\
\hline & $\begin{array}{c}\text { Colisão } \\
\text { Transversal }\end{array}$ & $\begin{array}{l}\text { Colisão } \\
\text { Lateral }\end{array}$ & $\begin{array}{c}\text { Colisão } \\
\text { Traseira }\end{array}$ & $\begin{array}{l}\text { Choque em } \\
\text { veículo } \\
\text { estacionado } \\
\end{array}$ & $\begin{array}{l}\text { Queda de } \\
\text { passageiro }\end{array}$ & $\begin{array}{l}\text { Colisão } \\
\text { Frontal }\end{array}$ & $\begin{array}{l}\text { Atrop. de } \\
\text { pedestre }\end{array}$ & $\begin{array}{l}\text { Choque em } \\
\text { objeto fixo }\end{array}$ \\
\hline Danos Materiais & $88 \quad(72,73 \%)$ & $77 \quad(83,70 \%)$ & $57 \quad(91,94 \%)$ & $41 \quad(100,00 \%)$ & 0 & $4 \quad(36,36 \%)$ & 0 & $2(100,00 \%)$ \\
\hline $\begin{array}{l}\text { Vítima Não } \\
\text { Fatal }\end{array}$ & $31(25,62 \%)$ & $15(16,30 \%)$ & $5 \quad(8,06 \%)$ & 0 & $10 \quad(100,00 \%)$ & $6(54,55 \%)$ & $2(66,67 \%)$ & 0 \\
\hline Vítima Fatal & $2(1,65 \%)$ & 0 & 0 & 0 & 0 & $1 \quad(9,09 \%)$ & $1 \quad(33,33 \%)$ & 0 \\
\hline Total & $\begin{array}{c}121 \\
(100,00 \%) \\
\end{array}$ & $\begin{array}{c}92 \\
(100,00 \%) \\
\end{array}$ & $\begin{array}{c}62 \\
(100,00 \%) \\
\end{array}$ & $\begin{array}{c}41 \\
(100,00 \%) \\
\end{array}$ & $\begin{array}{c}10 \\
(100,00 \%) \\
\end{array}$ & $\begin{array}{c}11 \\
(100,00 \%) \\
\end{array}$ & $\begin{array}{c}3 \\
(100,00 \%) \\
\end{array}$ & $\begin{array}{c}2 \\
(100,00 \%) \\
\end{array}$ \\
\hline
\end{tabular}




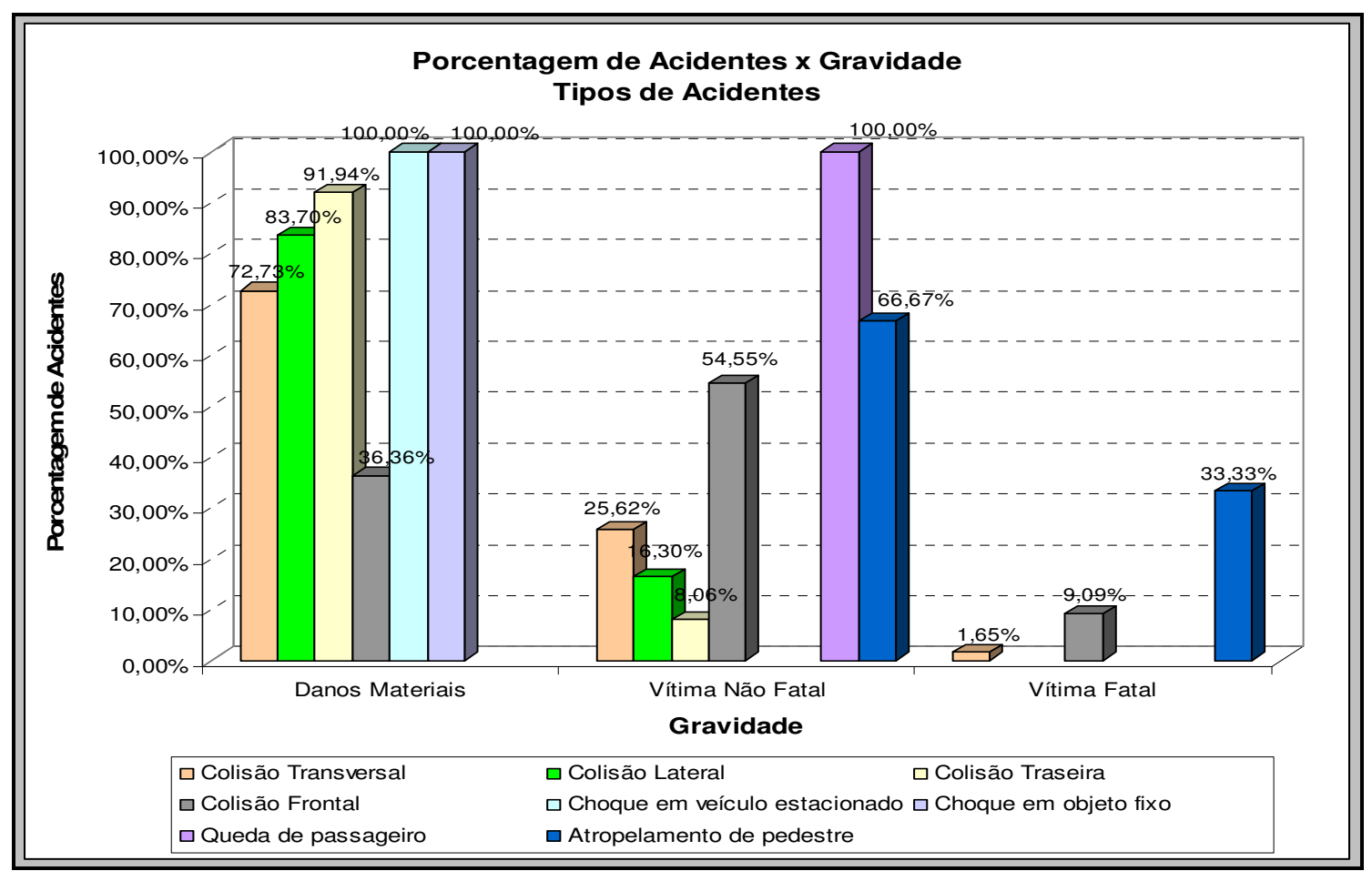

Figura 4.5: Porcentagem de acidentes de trânsito envolvendo o transporte coletivo de acordo com o tipo considerando a gravidade.

\subsubsection{Dia da Semana}

A distribuição dos acidentes nos diversos dias da semana é indicada na Tabela 4.4 e na Figura 4.6.

Tabela 4.4: Número de acidentes de trânsito envolvendo o transporte coletivo de acordo com o dia da semana.

\section{Dia da Semana \\ Total \\ Biênio 2005 - 2006}

\begin{tabular}{lcl}
\hline Segunda-feira & 54 & $(15,79 \%)$ \\
Terça-feira & 56 & $(16,37 \%)$ \\
Quarta-feira & 46 & $(13,45 \%)$ \\
Quinta-feira & 49 & $(14,33 \%)$ \\
Sexta-feira & 58 & $(16,96 \%)$ \\
Sábado & 45 & $(13,16 \%)$ \\
Domingo & 34 & $(9,94 \%)$ \\
\hline Total & $\mathbf{3 4 2}$ & $(\mathbf{1 0 0 , 0 0 \%})$ \\
\hline
\end{tabular}




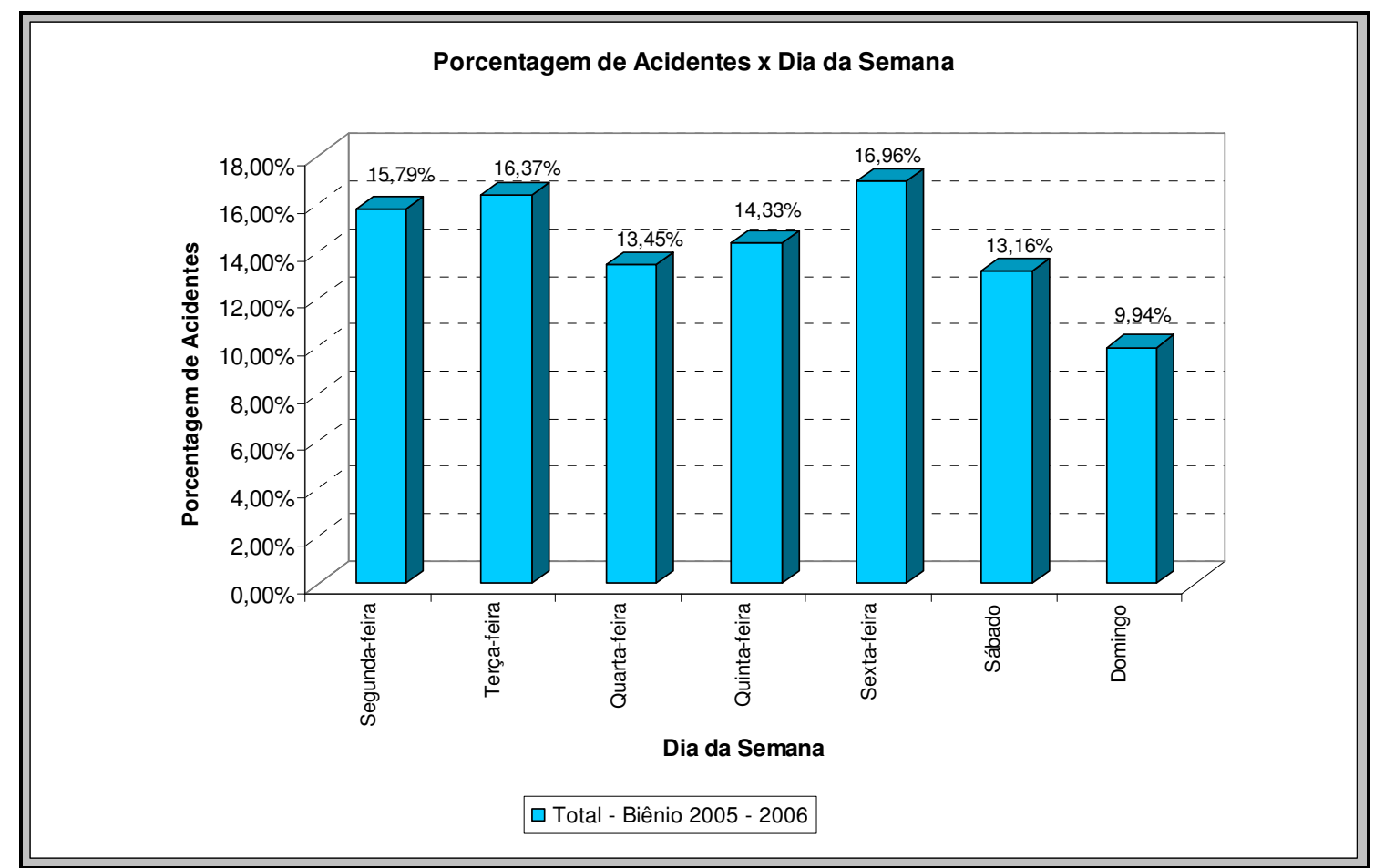

Figura 4.6: Porcentagem de acidentes de trânsito envolvendo o transporte coletivo de acordo com o dia da semana.

A distribuição dos acidentes nos dias da semana considerando a gravidade dos mesmos é mostrada na Tabela 4.5 e na Figura 4.7. 
Tabela 4.5: Número de acidentes de trânsito envolvendo o transporte coletivo de acordo com o dia da semana considerando a gravidade.

\begin{tabular}{|c|c|c|c|c|c|c|c|c|c|c|c|c|c|}
\hline \multirow{3}{*}{$\begin{array}{c}\begin{array}{c}\text { Gravidade dos } \\
\text { Acidentes }\end{array} \\
\text { Danos Materiais }\end{array}$} & \multicolumn{13}{|c|}{ Dias da Semana } \\
\hline & \multicolumn{2}{|c|}{ Segunda-feira } & \multicolumn{2}{|c|}{ Terça-feira } & \multicolumn{2}{|c|}{ Quarta-feira } & \multicolumn{2}{|c|}{ Quinta-feira } & \multicolumn{2}{|c|}{ Sexta-feira } & \multicolumn{2}{|r|}{ Sábado } & Domingo \\
\hline & 47 & $(87,04 \%)$ & 45 & $(80,36 \%)$ & 35 & $(76,09 \%)$ & 40 & $(81,63 \%)$ & 36 & $(62,07 \%)$ & 39 & $(86,67 \%)$ & $27 \quad(79,41 \%)$ \\
\hline Vítima Não Fatal & 7 & $(12,96 \%)$ & 10 & $(17,86 \%)$ & 11 & $(23,91 \%)$ & 9 & $(18,37 \%)$ & 21 & $(36,21 \%)$ & 6 & $(13,33 \%)$ & $5 \quad(14,71 \%)$ \\
\hline Vítima Fatal & & 0 & 1 & $(1,79 \%)$ & & 0 & & 0 & 1 & $(1,72 \%)$ & & 0 & $2 \quad(5,88 \%)$ \\
\hline Total & 54 & $(100,00 \%)$ & 56 & $(100,00 \%)$ & 46 & $(100,00 \%)$ & 49 & $(100,00 \%)$ & 58 & $(100,00 \%)$ & 45 & $(100,00 \%)$ & $34(100,00 \%)$ \\
\hline
\end{tabular}




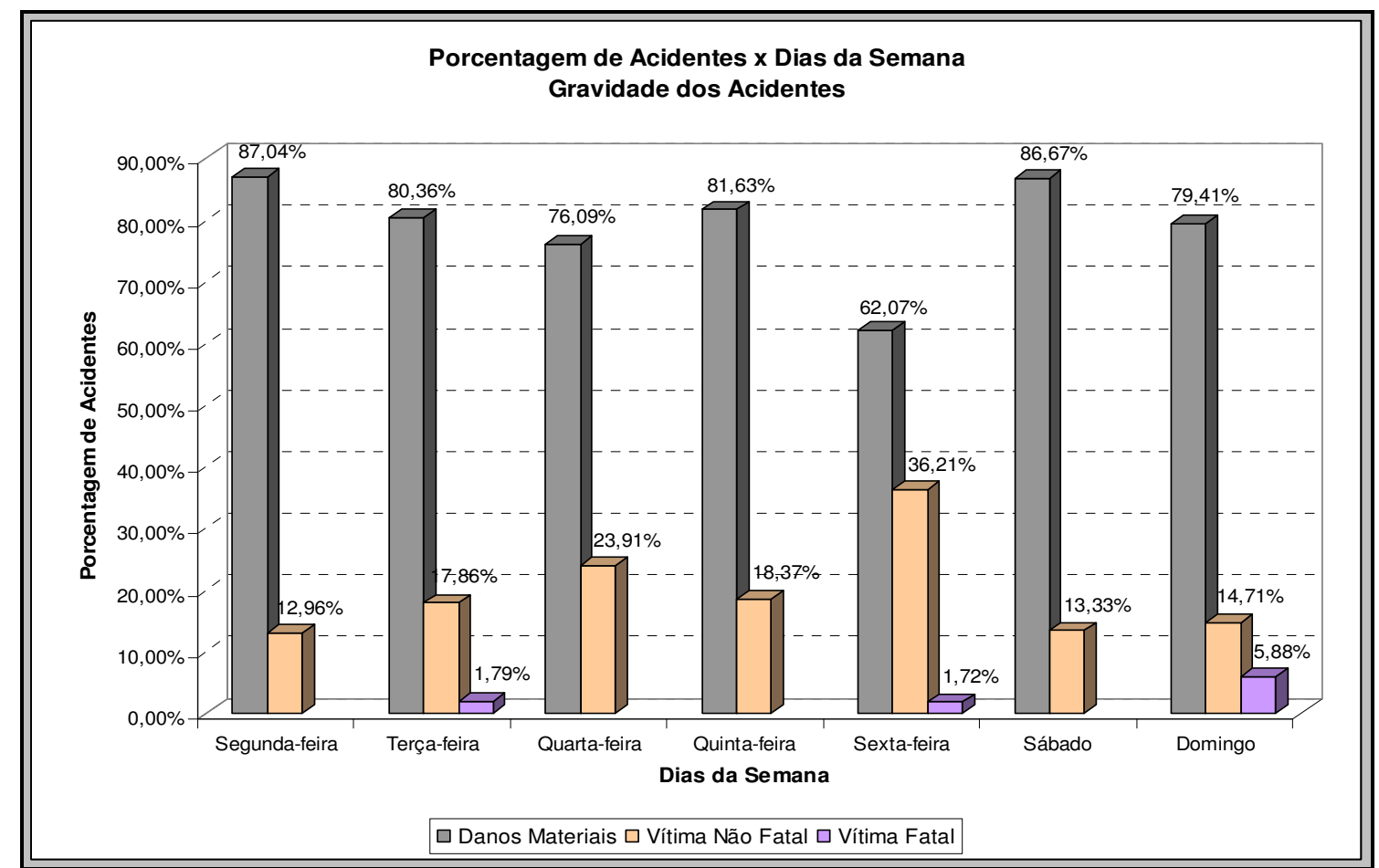

Figura 4.7: Porcentagem de acidentes de trânsito envolvendo o transporte coletivo de acordo com o dia da semana considerando a gravidade.

A distribuição dos acidentes nos dias da semana considerando o tipo de acidente é mostrada na Tabela 4.6 e na Figura 4.8. 
Tabela 4.6: Número de acidentes de trânsito envolvendo o transporte coletivo de acordo com o dia da semana considerando o tipo.

\begin{tabular}{|c|c|c|c|c|c|c|c|}
\hline \multirow{2}{*}{$\begin{array}{c}\text { Tipos de } \\
\text { Acidentes }\end{array}$} & \multicolumn{7}{|c|}{ Dias da Semana } \\
\hline & Segunda-feira & Terça-feira & Quarta-feira & Quinta-feira & Sexta-feira & Sábado & Domingo \\
\hline $\begin{array}{l}\text { Atropelamento } \\
\text { de pedestre }\end{array}$ & 0 & $1(1,79 \%)$ & 0 & $2(4,08 \%)$ & 0 & 0 & 0 \\
\hline $\begin{array}{l}\text { Choque em } \\
\text { objeto fixo }\end{array}$ & 0 & 0 & $1(2,17 \%)$ & 0 & 0 & $1(2,22 \%)$ & 0 \\
\hline $\begin{array}{l}\text { Choque em } \\
\text { veículo } \\
\text { estacionado }\end{array}$ & $9(16,67 \%)$ & $6(10,71 \%)$ & $6(13,04 \%)$ & $6(12,24 \%)$ & $9(15,52 \%)$ & $4 \quad(8,89 \%)$ & $1 \quad(2,94 \%)$ \\
\hline Colisão Frontal & $1 \quad(1,85 \%)$ & $1 \quad(1,79 \%)$ & $1 \quad(2,17 \% 0$ & $1(2,04 \%)$ & $3(5,17 \%)$ & $2(4,44 \%)$ & $2(5,88 \%)$ \\
\hline Colisão Lateral & $13(24,07 \%)$ & $15(26,79 \%)$ & $16(34,78 \%)$ & $9 \quad(18,37 \%)$ & $15(25,86 \%)$ & $14(31,11 \%)$ & $\begin{array}{c}10 \\
(29,41 \%)\end{array}$ \\
\hline $\begin{array}{l}\text { Colisão } \\
\text { Transversal }\end{array}$ & $17(31,48 \%)$ & $19(33,93 \%)$ & $14(30,43 \%)$ & $16(32,65 \%)$ & $21 \quad(36,21 \%)$ & $17(37,78 \%)$ & $\begin{array}{c}17 \\
(50,00 \%)\end{array}$ \\
\hline Colisão Traseira & $12(22,22 \%)$ & $14(25,00 \%)$ & $7 \quad(15,22 \%)$ & $13(26,53 \%)$ & $7 \quad(12,07 \%)$ & $6 \quad(13,33 \%)$ & $3(8,82 \%)$ \\
\hline $\begin{array}{l}\text { Queda de } \\
\text { passageiro }\end{array}$ & $2(3,70 \%)$ & 0 & $1 \quad(2,17 \%)$ & $2(4,08 \%)$ & $3(5,17 \%)$ & $1 \quad(2,22 \%)$ & $1 \quad(2,94 \%)$ \\
\hline Total & $54 \quad(100,00 \%)$ & $56 \quad(100,00 \%)$ & $46 \quad(100,00 \%)$ & $49(100,00 \%)$ & $58(100,00 \%)$ & $45 \quad(100,00 \%)$ & $34 \quad(100 \%$ \\
\hline
\end{tabular}




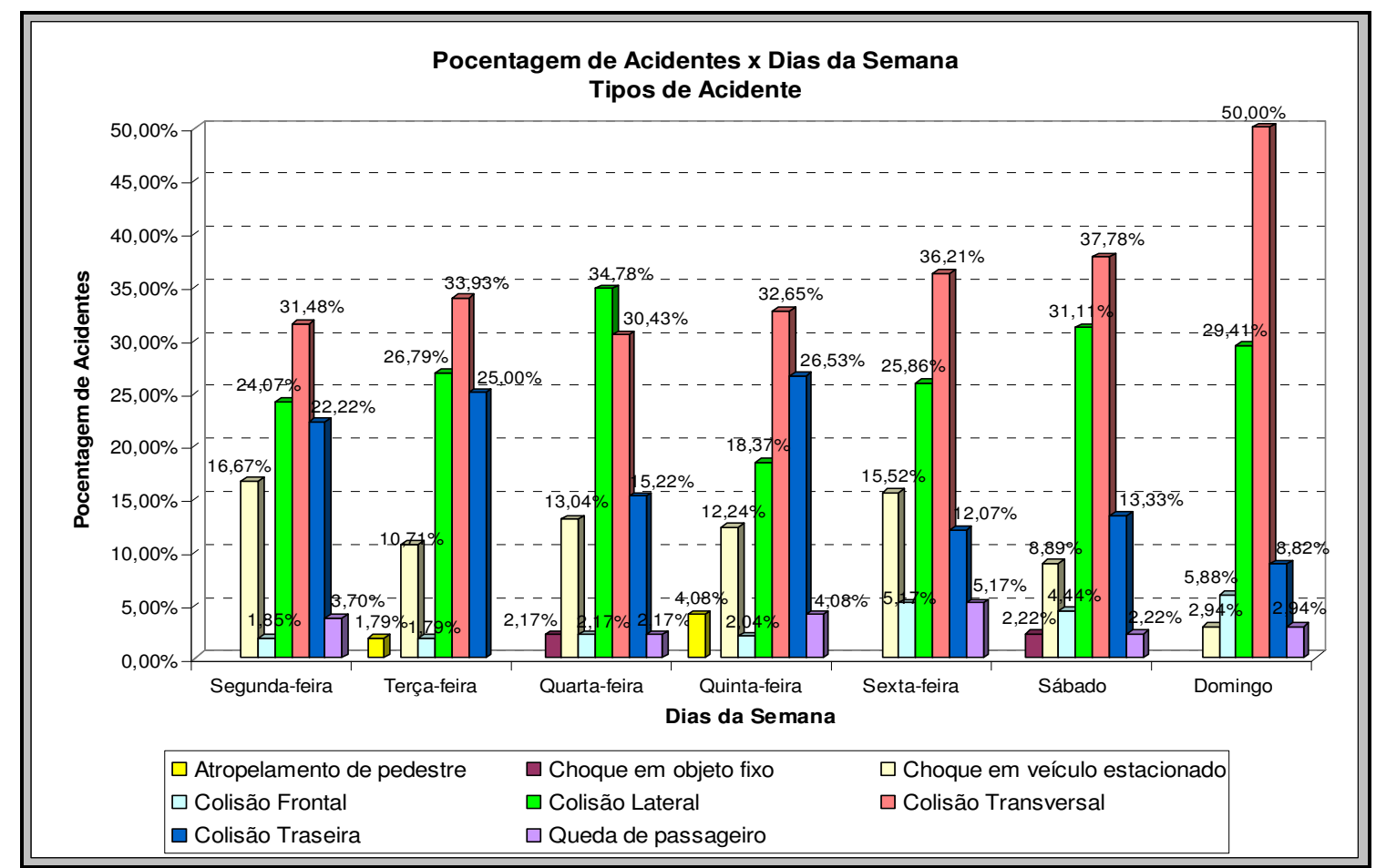

Figura 4.8: Porcentagem de acidentes de trânsito envolvendo o transporte coletivo de acordo com o dia da semana considerando o tipo.

\subsubsection{Mês do Ano}

A distribuição dos acidentes nos meses do ano encontra-se indicada na Tabela 4.7 e na Figura 4.9.

Tabela 4.7: Número de acidentes de trânsito envolvendo o transporte coletivo de acordo com os meses do ano.

\section{Meses do ano}

\section{Total}

Biênio 2005 - 2006

\begin{tabular}{lccc}
\hline Janeiro & 29 & $(8,48 \%)$ \\
Fevereiro & 16 & $(4,68)$ \\
Março & 27 & $(7,89 \%)$ \\
Abril & 23 & $(6,73 \%)$ \\
Maio & 27 & $(7,89 \%)$ \\
Junho & 31 & $(9,06 \%)$ \\
Julho & 24 & $(7,02 \%)$ \\
Agosto & 28 & $(8,19 \%)$ \\
Setembro & 28 & $(8,19 \%)$ \\
Outubro & 36 & $(10,53 \%)$ & \\
Novembro & 40 & $(11,70 \%)$ & \\
& & & Continua
\end{tabular}




\begin{tabular}{|c|c|}
\hline Meses do ano & $\begin{array}{c}\text { Total } \\
\text { Biênio } 2005-2006 \\
\end{array}$ \\
\hline Dezembro & $33(9,65 \%)$ \\
\hline Total & $342(100,00 \%)$ \\
\hline
\end{tabular}

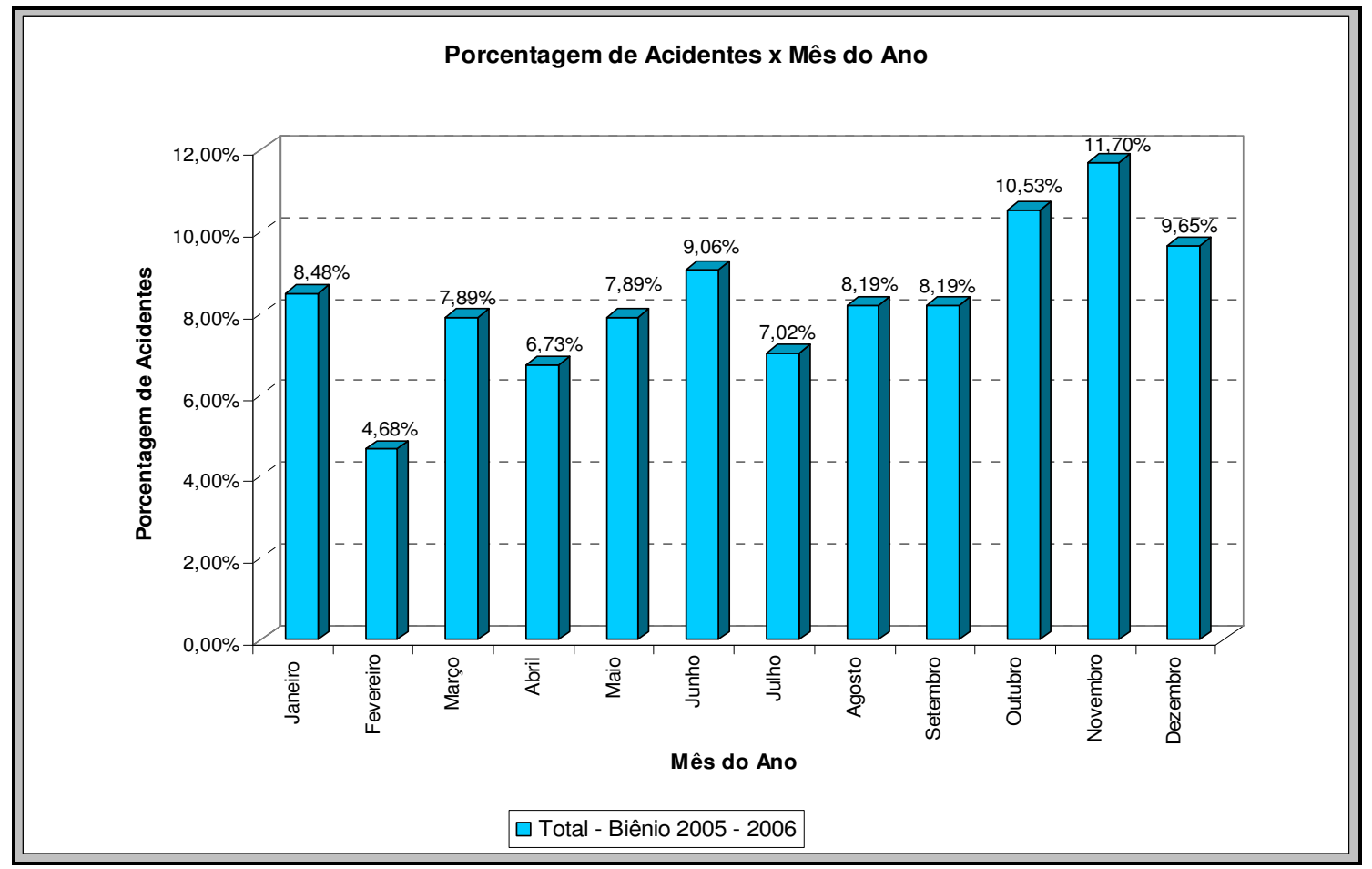

Figura 4.9: Porcentagem de acidentes de trânsito envolvendo o transporte coletivo de acordo com os meses do ano.

\subsubsection{Período do dia}

A repartição dos acidentes quanto ao período do dia em que ocorreram é mostrada na Tabela 4.8 e na Figura 4.10.

Tabela 4.8: Número de acidentes de trânsito envolvendo o transporte coletivo de acordo com o período do dia.

Período do dia

Total

Biênio 2005 - 2006

\begin{tabular}{lcc}
\hline Diurno & 283 & $(82,75 \%)$ \\
Noturno & 59 & $(17,25 \%)$ \\
\hline Total & $\mathbf{3 4 2}$ & $\mathbf{( 1 0 0 , 0 0 \% )}$ \\
\hline
\end{tabular}




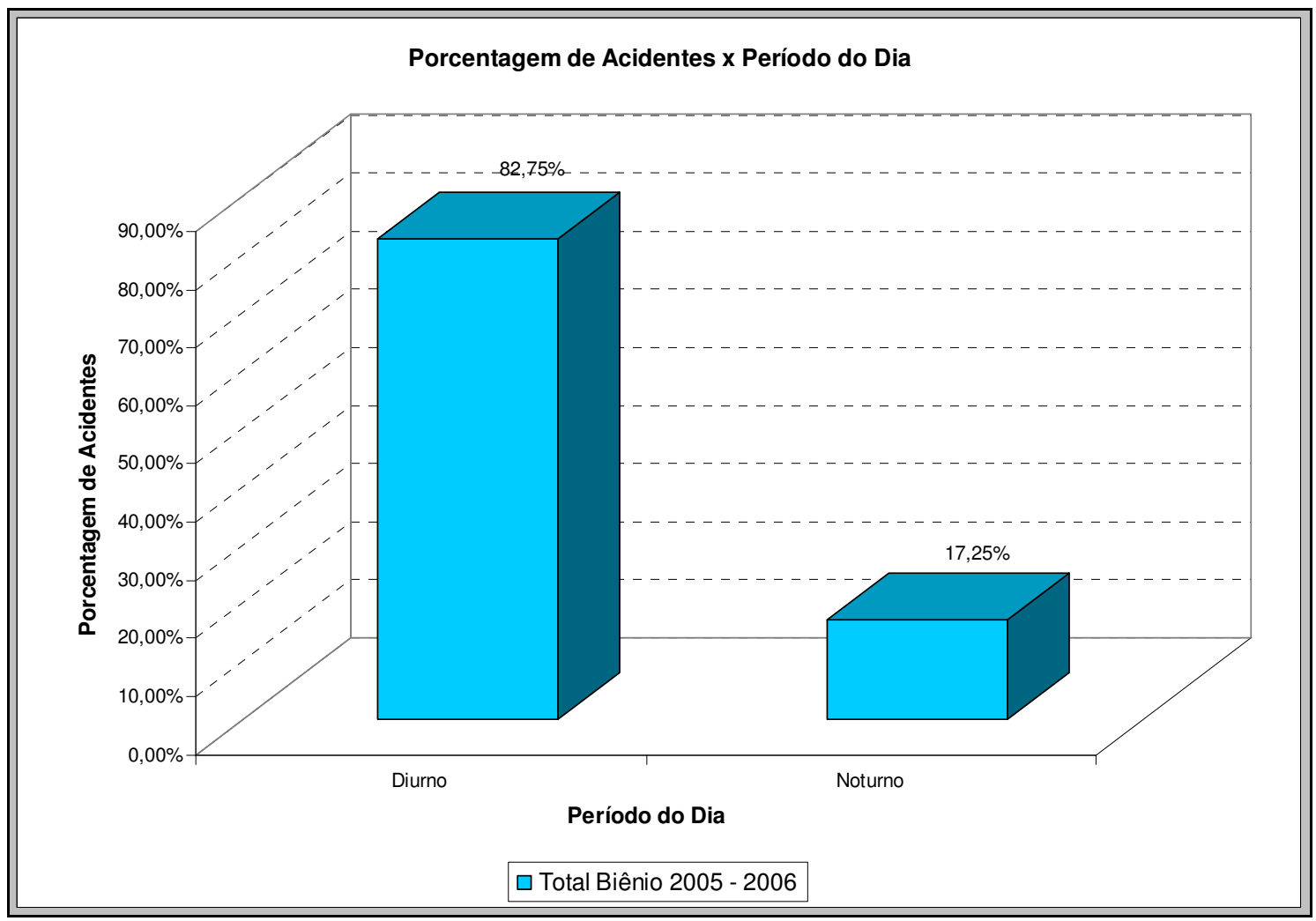

Figura 4.10: Porcentagem de acidentes de trânsito envolvendo o transporte coletivo de acordo com o período do dia.

A distribuição dos acidentes nos diversos períodos do dia considerando a gravidade dos mesmos é mostrada na Tabela 4.9 e na Figura 4.11.

Tabela 4.9: Número de acidentes de trânsito envolvendo o transporte coletivo de acordo com o período do dia considerando a gravidade.

\begin{tabular}{lrlrl}
\hline \multirow{2}{*}{ Gravidade dos Acidentes } & \multicolumn{3}{c}{ Período do Dia } \\
\cline { 2 - 5 } & \multicolumn{2}{c}{ Diurno } & \multicolumn{2}{c}{ Noturno } \\
\hline Danos Materiais & 217 & $(79,78 \%)$ & 52 & $(74,29 \%)$ \\
Vítima Não Fatal & 52 & $(19,12 \%)$ & 17 & $(24,29 \%)$ \\
Vítima Fatal & 3 & $(1,10 \%)$ & 1 & $(1,43 \%)$ \\
\hline Total & $\mathbf{2 7 2}$ & $\mathbf{( 1 0 0 , 0 0 \% )}$ & $\mathbf{7 0}$ & $\mathbf{( 1 0 0 , 0 0 \% )}$ \\
\hline
\end{tabular}




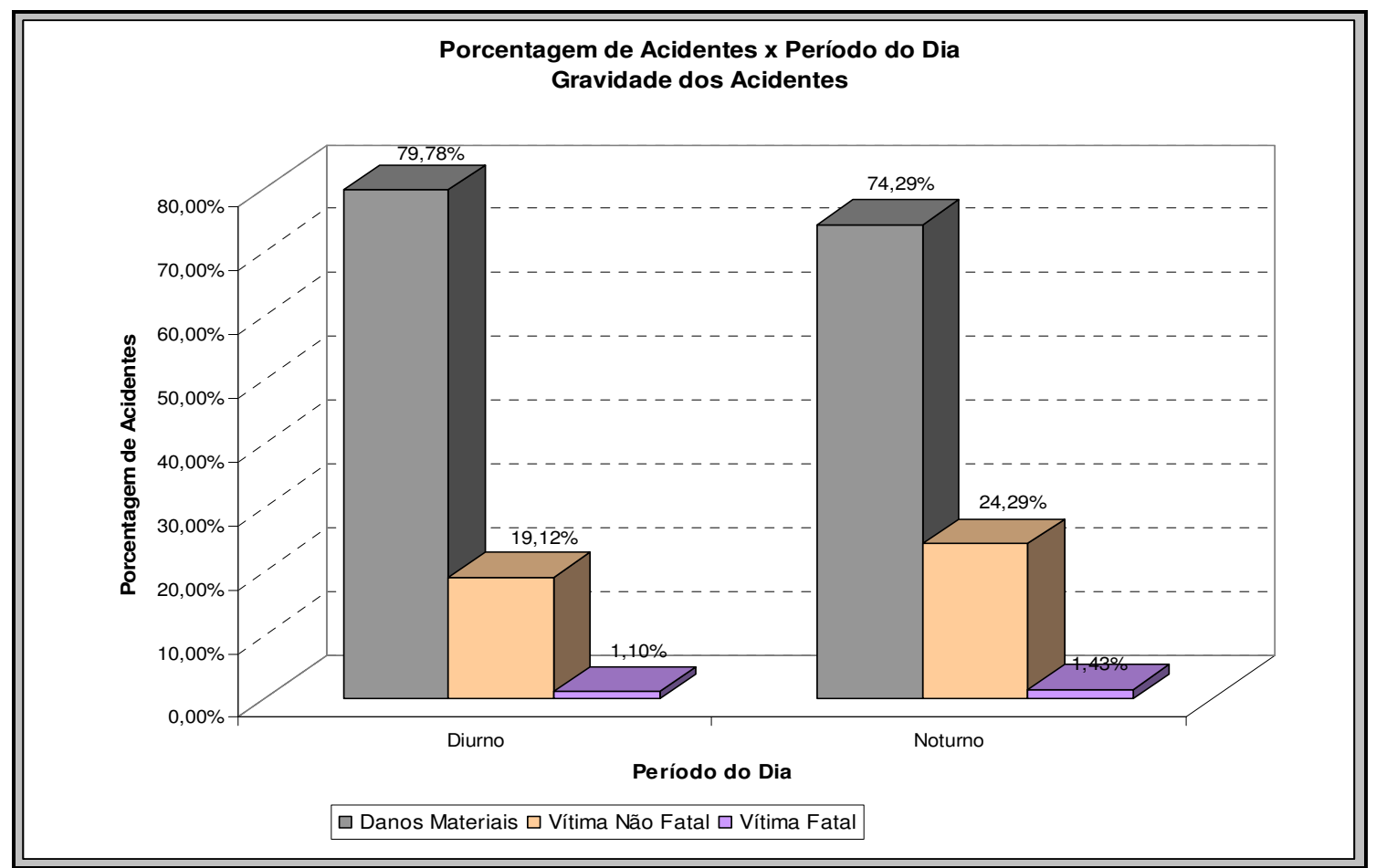

Figura 4.11: Porcentagem de acidentes de trânsito envolvendo o transporte coletivo de acordo com o período do dia considerando a gravidade.

A distribuição dos acidentes nos diversos períodos do dia considerando o tipo de acidente é mostrada na Tabela 4.10 e na Figura 4.12.

Tabela 4.10: Número de acidentes de trânsito envolvendo o transporte coletivo de acordo com o período do dia considerando os tipos de acidentes.

\begin{tabular}{lrlrc}
\hline \multirow{2}{*}{ Tipos de Acidentes } & \multicolumn{4}{c}{ Período do Dia } \\
\cline { 2 - 6 } & \multicolumn{2}{c}{ Diurno } & \multicolumn{2}{c}{ Noturno } \\
\hline Colisão Transversal & 90 & $(33,09 \%)$ & 31 & $(44,29 \%)$ \\
Colisão Lateral & 77 & $(28,31 \%)$ & 15 & $(21,43 \%)$ \\
Colisão Traseira & 55 & $(20,22 \%)$ & 7 & $(10,00 \%)$ \\
Choque em Veículo Estacionado & 31 & $(11,40 \%)$ & 10 & $(14,29 \%)$ \\
Queda de Passageiro & 10 & $(3,68 \%)$ & & 0 \\
Colisão Frontal & 6 & $(2,21 \%)$ & 5 & $(7,14 \%)$ \\
Atropelamento de Pedestre & 1 & $(0,37 \%)$ & 2 & $(2,86 \%)$ \\
Choque em Objeto Fixo & 2 & $(0,74 \%)$ & & 0 \\
\hline Total & $\mathbf{2 7 2}$ & $(\mathbf{1 0 0 , 0 0 \% )}$ & $\mathbf{7 0}$ & $(\mathbf{1 0 0 , 0 0 \% )}$ \\
\hline
\end{tabular}




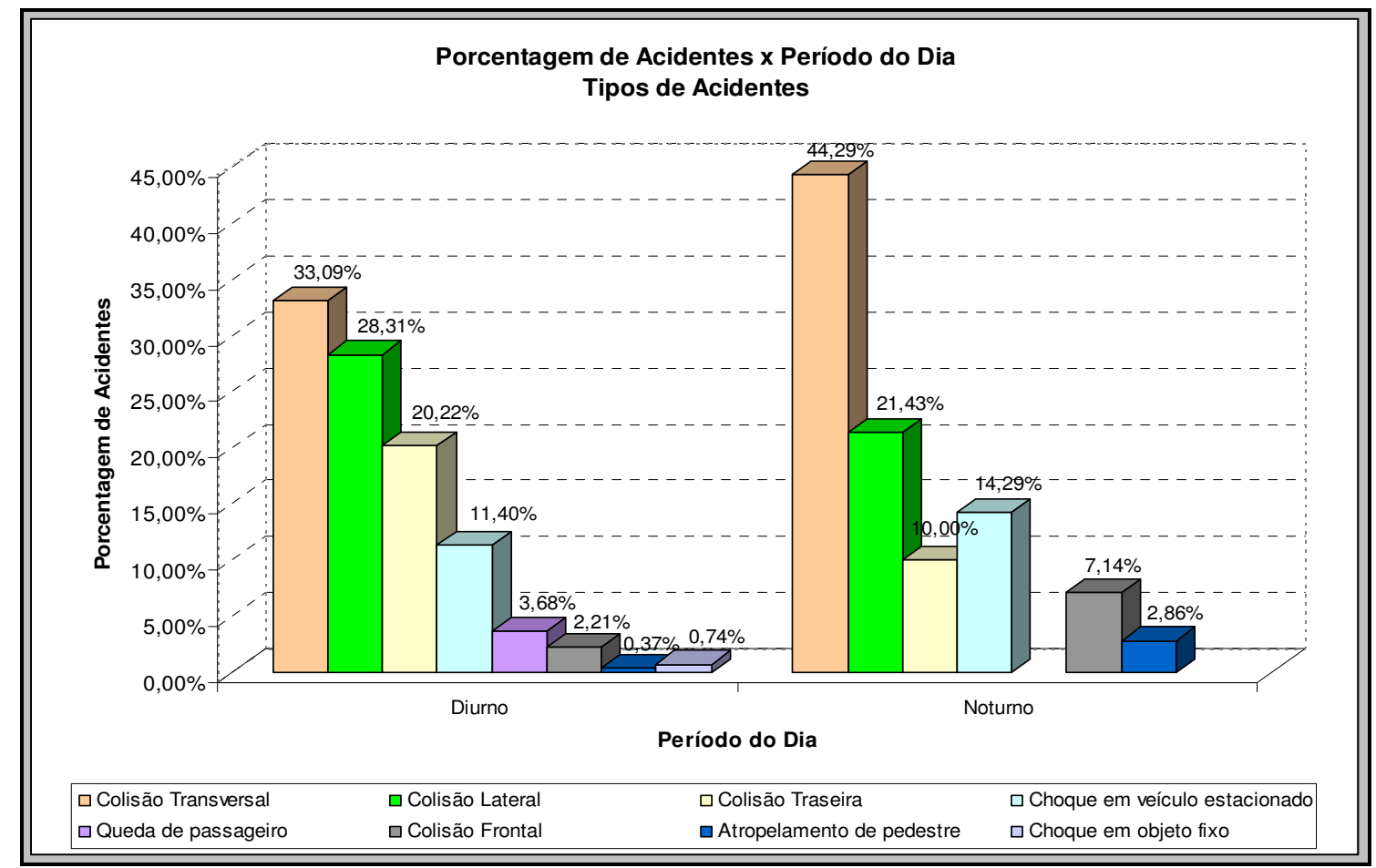

Figura 4.12: Porcentagem de acidentes de trânsito envolvendo o transporte coletivo de acordo com o período do dia considerando os tipos de acidentes.

\subsubsection{Intervalo horário}

A repartição dos acidentes quanto ao intervalo horário em que ocorreram é mostrada na Tabela 4.11 e na Figura 4.13.

Tabela 4.11: Número de acidentes de trânsito envolvendo o transporte coletivo de acordo com o intervalo horário.

\section{Intervalo Horário}

\section{Total}

Biênio 2005 - 2006

$\begin{array}{ccc}0-1 \mathrm{~h} & 0 \\ 1-2 \mathrm{~h} & 1 & (0,29 \%) \\ 2-3 \mathrm{~h} & & 0 \\ 3-4 \mathrm{~h} & & 0 \\ 4-5 \mathrm{~h} & & 0 \\ 5-6 \mathrm{~h} & & 0 \\ 6-7 \mathrm{~h} & 1 & (0,29 \%) \\ 7-8 \mathrm{~h} & 7 & (2,05 \%) \\ 8-9 \mathrm{~h} & 22 & (6,43 \%) \\ 9-10 \mathrm{~h} & 19 & (5,56 \%) \\ 10-11 \mathrm{~h} & 20 & (5,85 \%) \\ & 19 & (5,56 \%)\end{array}$




\begin{tabular}{|c|c|}
\hline Intervalo Horário & $\begin{array}{c}\text { Total } \\
\text { Biênio } 2005 \text { - } 2006 \\
\end{array}$ \\
\hline $11-12 \mathrm{~h}$ & $21 \quad(6,14 \%)$ \\
\hline $12-13 \mathrm{~h}$ & $35 \quad(10,23 \%)$ \\
\hline $13-14 \mathrm{~h}$ & $20 \quad(5,85 \%)$ \\
\hline $14-15 \mathrm{~h}$ & $33(9,65 \%)$ \\
\hline $15-16 \mathrm{~h}$ & $24 \quad(7,02 \%)$ \\
\hline $16-17 \mathrm{~h}$ & $25 \quad(7,31 \%)$ \\
\hline $17-18 \mathrm{~h}$ & $23(6,73 \%)$ \\
\hline $18-19 \mathrm{~h}$ & $23(6,73 \%)$ \\
\hline $19-20 \mathrm{~h}$ & $16(4,68 \%)$ \\
\hline $20-21 \mathrm{~h}$ & $6(1,75 \%)$ \\
\hline $21-22 \mathrm{~h}$ & $8 \quad(2,34 \%)$ \\
\hline $22-23 h$ & $13(3,80 \%)$ \\
\hline $23-24 h$ & $6 \quad(1,75 \%)$ \\
\hline Total & $342(100,00 \%)$ \\
\hline
\end{tabular}




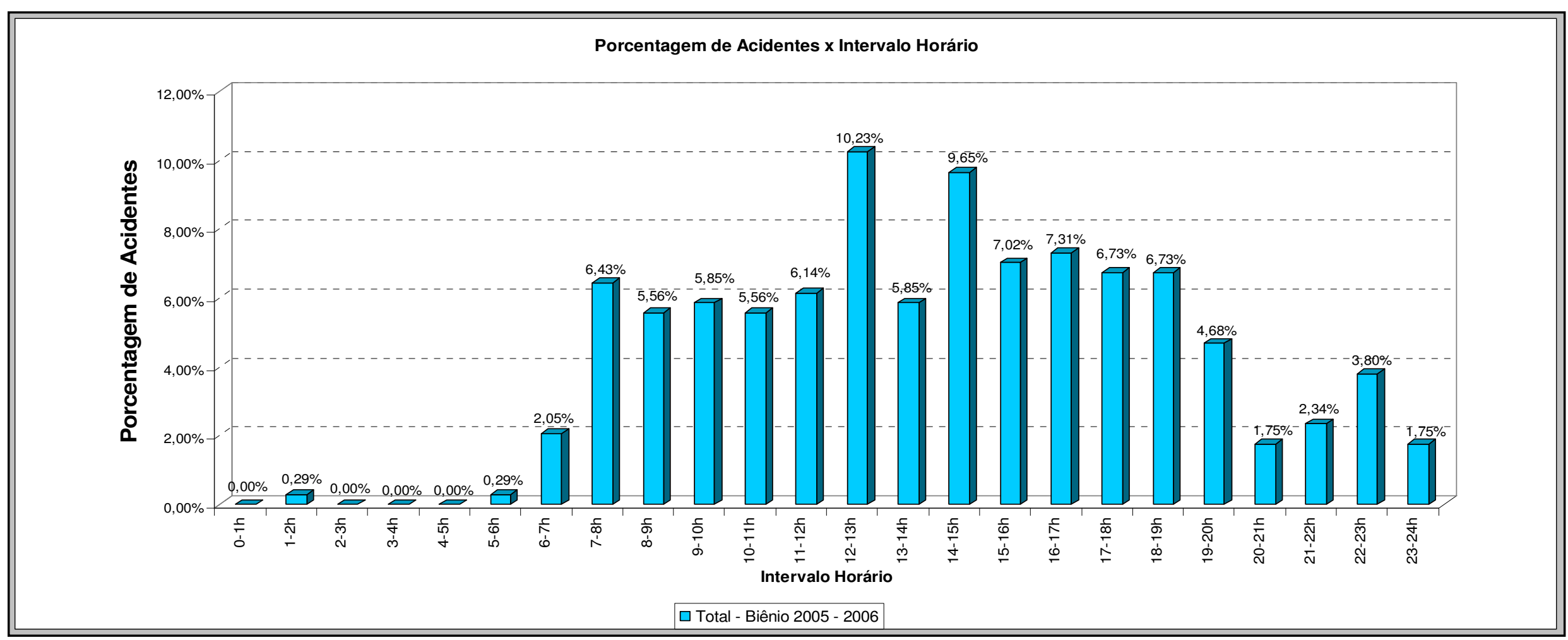

Figura 4.13: Porcentagem de acidentes de trânsito envolvendo o transporte coletivo de acordo com o intervalo horário. 


\subsubsection{Condições Meteorológicas}

A distribuição do acidentes considerando a existência ou não de chuva é mostrada na Tabela 4.12 e na Figura 4.14.

Tabela 4.12: Número de acidentes de trânsito envolvendo o transporte coletivo de acordo com condições meteorológicas.

Condições Meteorológicas

Total

Biênio 2005 - 2006

\begin{tabular}{lrl}
\hline Boa & 316 & $(92,40 \%)$ \\
Chuvosa & 24 & $(7,02 \%)$ \\
Não informada & 2 & $(0,58 \%)$ \\
\hline Total & $\mathbf{3 4 2}$ & $(\mathbf{1 0 0 , 0 0 \%})$ \\
\hline
\end{tabular}

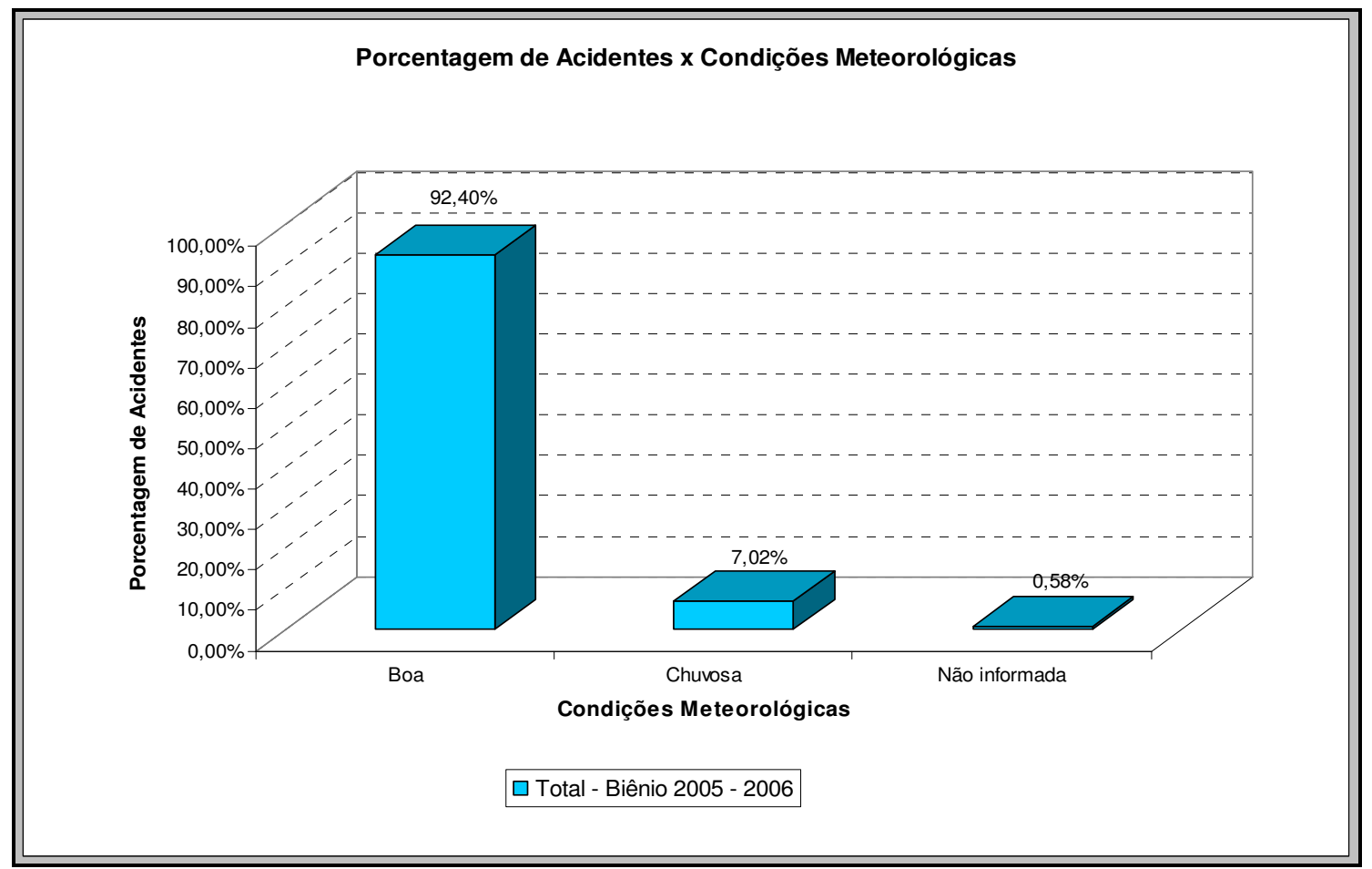

Figura 4.14: Porcentagem de acidentes de trânsito envolvendo o transporte coletivo de acordo com as condições meteorológicas.

A distribuição dos acidentes de acordo com a gravidade com condição meteorológica boa, chuvosa ou não informada está demonstrada na Tabela 4.13 e na Figura 4.15. 
Tabela 4.13: Número de acidentes de trânsito envolvendo o transporte coletivo de acordo com as condições meteorológicas considerando a gravidade.

\begin{tabular}{|c|c|c|c|}
\hline \multirow[b]{2}{*}{ Gravidade dos Acidentes } & \multicolumn{3}{|c|}{ Condição Meteorológica } \\
\hline & Boa & Chuvosa & $\begin{array}{c}\text { Não } \\
\text { informada }\end{array}$ \\
\hline Danos Materiais & $249(78,80 \%)$ & $18(75,00 \%)$ & $2(100,00 \%)$ \\
\hline Vítima Não Fatal & $63(19,94 \%)$ & $6(25,00 \%)$ & 0 \\
\hline Vítima Fatal & $4(1,27 \%)$ & 0 & 0 \\
\hline Total & $316(100,00 \%)$ & $24(100,00 \%)$ & $2(100,00 \%)$ \\
\hline
\end{tabular}

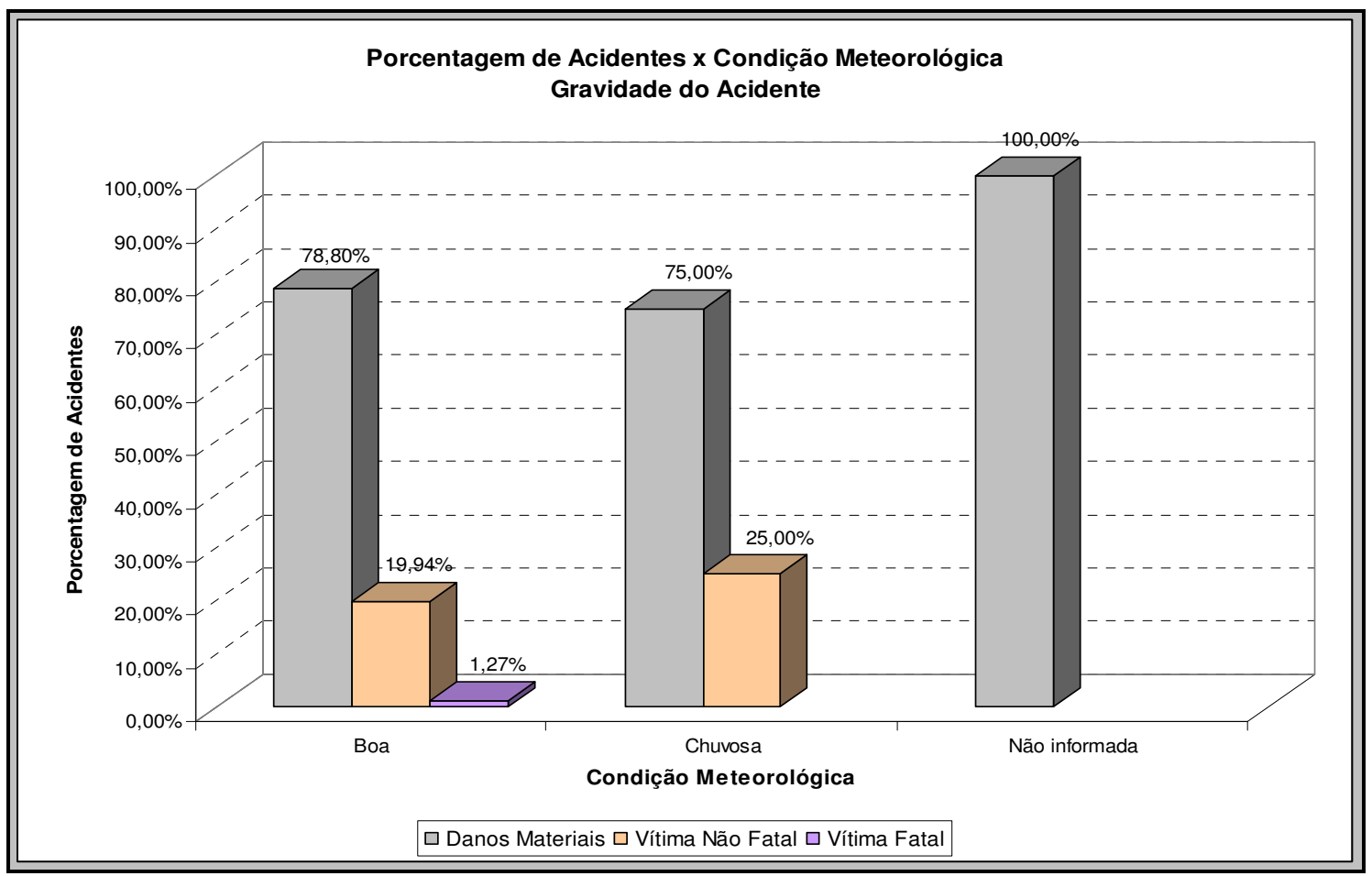

Figura 4.15: Porcentagem de acidentes de trânsito envolvendo o transporte coletivo de acordo com as condições meteorológicas considerando a gravidade

A distribuição dos acidentes de trânsito de acordo com as condições meteorológicas considerando os tipos de acidentes é indicada na Tabela 4.14 e na Figura 4.16.

Tabela 4.14: Número de acidentes de trânsito envolvendo o transporte coletivo de acordo com as condições meteorológicas considerando os tipos de acidentes.

\begin{tabular}{lccc}
\hline \multirow{2}{*}{ Tipo de Acidentes de Trânsito } & \multicolumn{3}{c}{ Condição Meteorológica } \\
\cline { 2 - 5 } & Boa & Chuvosa & $\begin{array}{c}\text { Não } \\
\text { informada }\end{array}$ \\
\hline Atropelamento de pedestre & $3(0,95 \%)$ & 0 & 0 \\
Colisão em veículo estacionado & $41(12,97 \%)$ & 0 & 0 \\
& & &
\end{tabular}




\begin{tabular}{lcccc}
\hline Tipo de Acidentes de Trânsito & Boa & Chuvosa & $\begin{array}{c}\text { Não } \\
\text { informada }\end{array}$ \\
\hline Colisão Frontal & $10(3,16 \%)$ & $1(4,17)$ & \\
Colisão Lateral & $87(27,53 \%)$ & $3(12,50 \%)$ & 2 & $(100,00 \%)$ \\
Colisão Transversal & $107(33,86 \%)$ & $14(58,33 \%)$ & 0 \\
Colisão Traseira & $57(18,04 \%)$ & $5(20,83 \%)$ & 0 \\
Queda de passageiro & $9(2,85 \%)$ & $1(4,17 \%)$ & 0 \\
Colisão em objeto fixo & $2(0,63 \%)$ & 0 & 0 \\
\hline Total & $\mathbf{3 1 6}(\mathbf{( 1 0 0 , 0 0 \% )}$ & $\mathbf{2 4}$ & $\mathbf{( 1 0 0 , 0 0 \% )}$ & $\mathbf{2}(\mathbf{( 1 0 0 , 0 0 \% )}$ \\
\hline
\end{tabular}

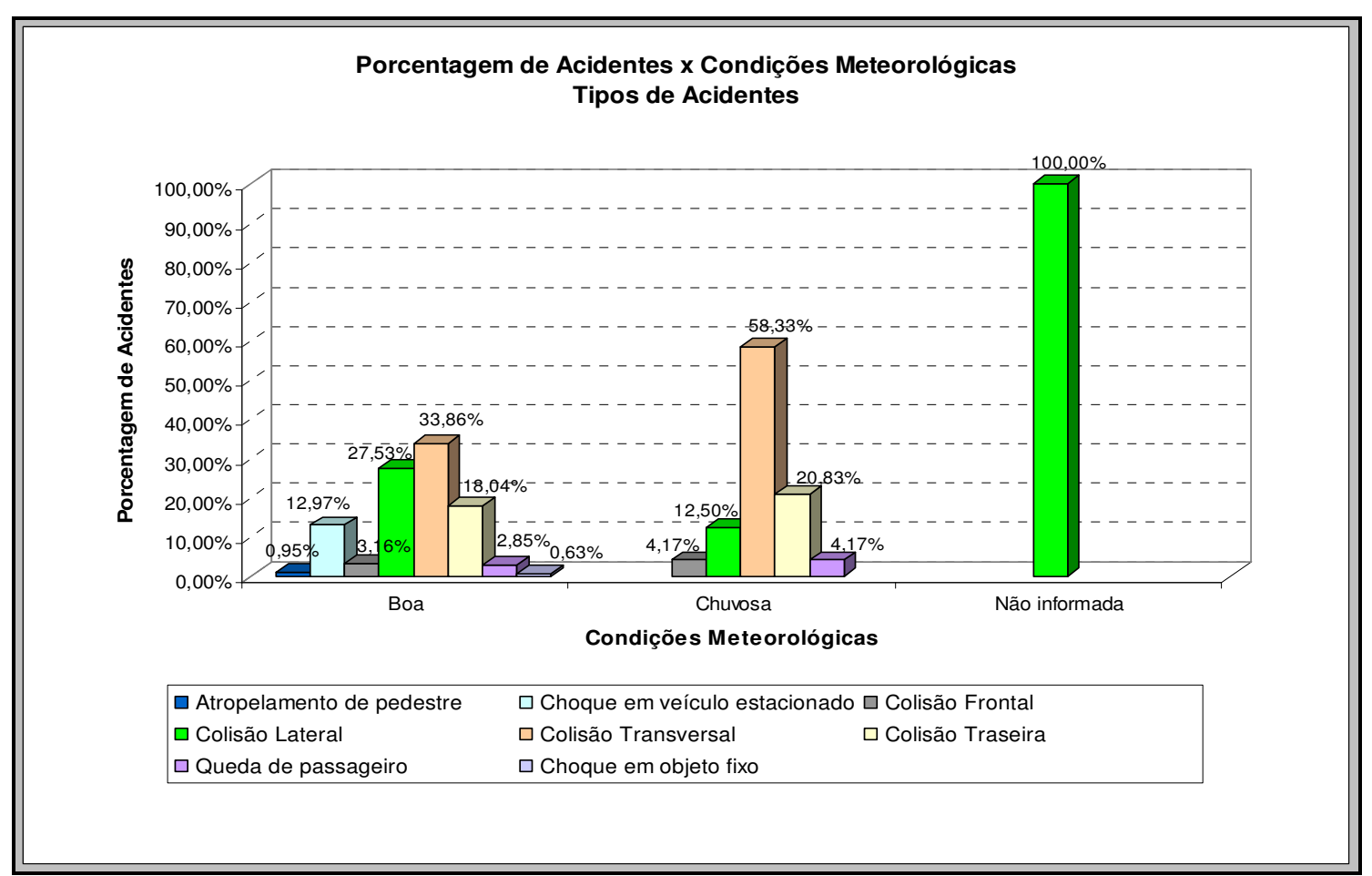

Figura 4.16: Porcentagem de acidentes de trânsito envolvendo o transporte coletivo de acordo com as condições meteorológicas considerando os tipos de acidentes.

\subsection{DISTRIBUIÇÃO ESPACIAL DOS ACIDENTES}

\subsubsection{Georreferenciamento dos acidentes de trânsito}

A distribuição espacial dos acidentes de trânsito envolvendo os veículos de transporte coletivo é mostrada na Figura 4.17. 


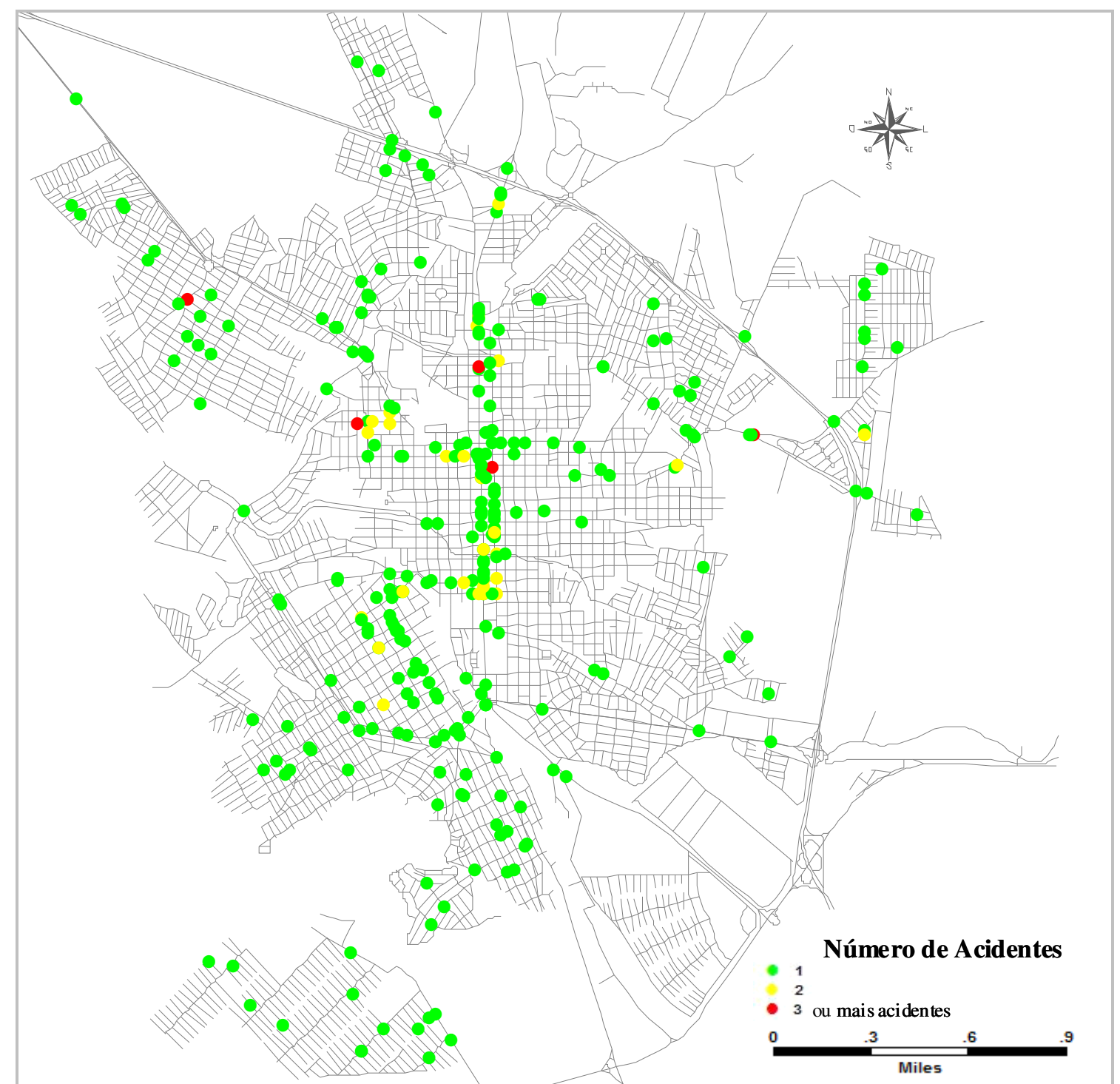

Figura 4.17: Mapa referente à distribuição espacial dos acidentes de trânsito no biênio 2005 - 2006 .

A distribuição dos acidentes que resultaram na ocorrência de vítimas (fatais e não fatais) é mostrada na Figura 4.18. 


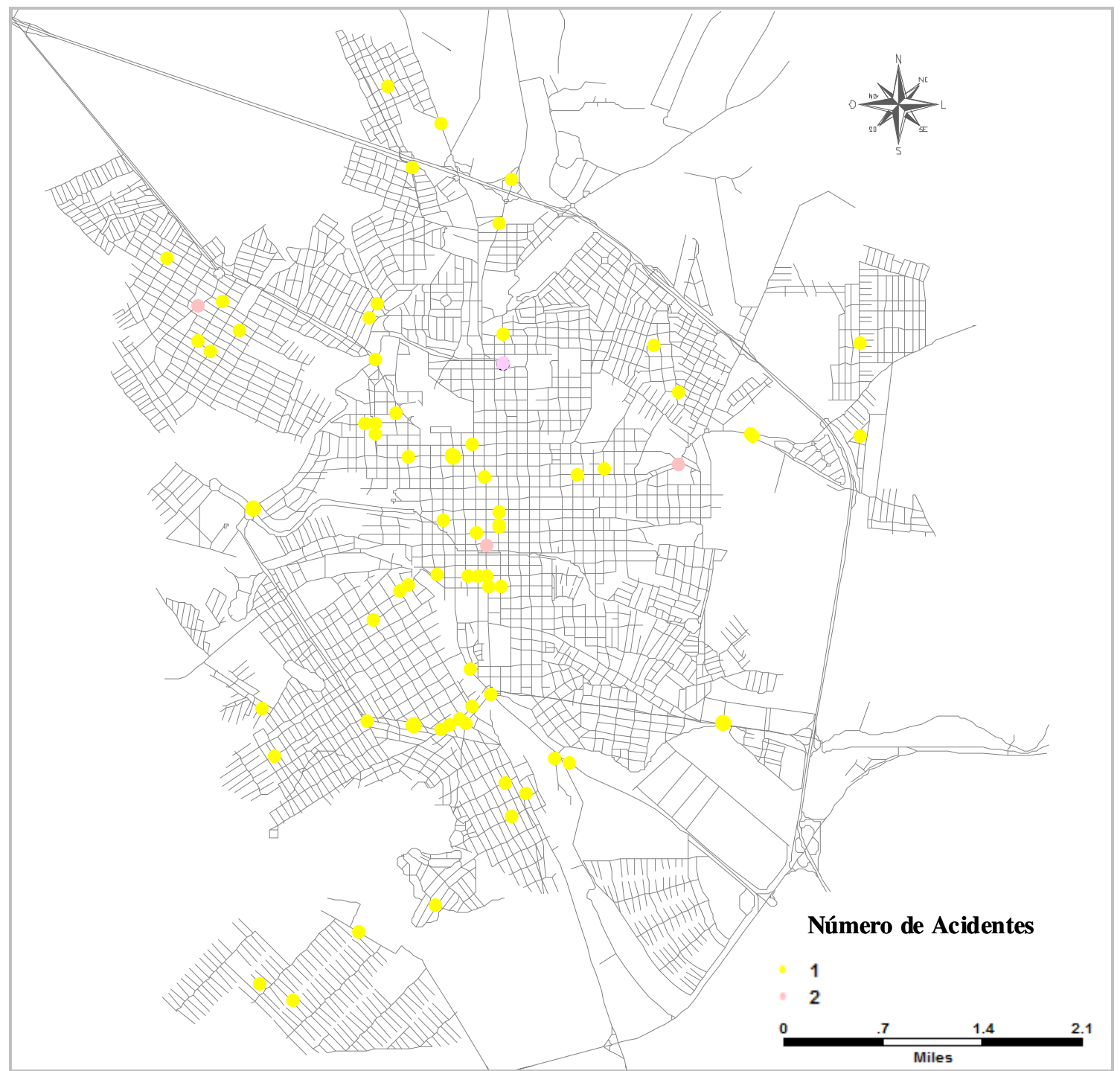

Figura 4.18: Mapa referente à distribuição espacial dos acidentes de trânsito com vítimas no biênio $2005-2006$.

Com relação à distribuição dos acidentes que resultaram em vítimas fatais, a mesma é mostrada na Figura 4.19. 


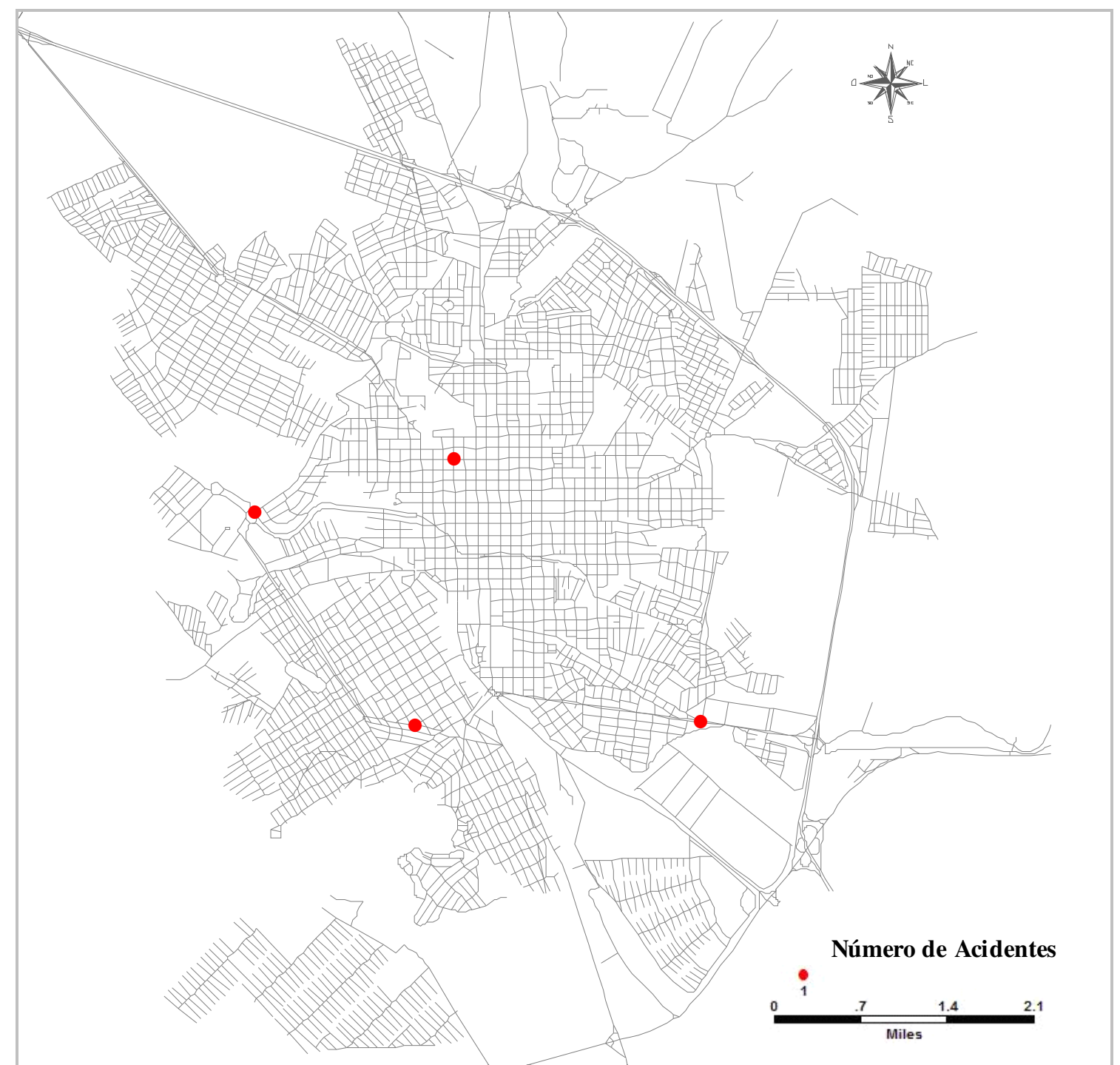

Figura 4.19: Mapa referente à distribuição espacial dos acidentes de trânsito com vítimas fatais no biênio $2005-2006$.

Acidentes de trânsito envolvendo os veículos de transporte coletivo ocorreram em todos os pontos da malha viária da cidade de São Carlos, em interseções e ao longo das vias. A distribuição da localização dos acidentes no biênio 2005 - 2006 é indicada na Tabela 4.15 e Figura 4.20. 
Tabela 4.15: Número de acidentes de trânsito envolvendo o transporte coletivo de acordo com o local de ocorrência

\section{Local de Ocorrência}

\section{Total}

Biênio 2005 - 2006

\begin{tabular}{lcc}
\hline Ao longo das vias & 205 & $(59,94 \%)$ \\
Em interseções & 137 & $(40,06 \%)$ \\
\hline Total & $\mathbf{3 4 2}$ & $\mathbf{( 1 0 0 , 0 0 \% )}$ \\
\hline
\end{tabular}

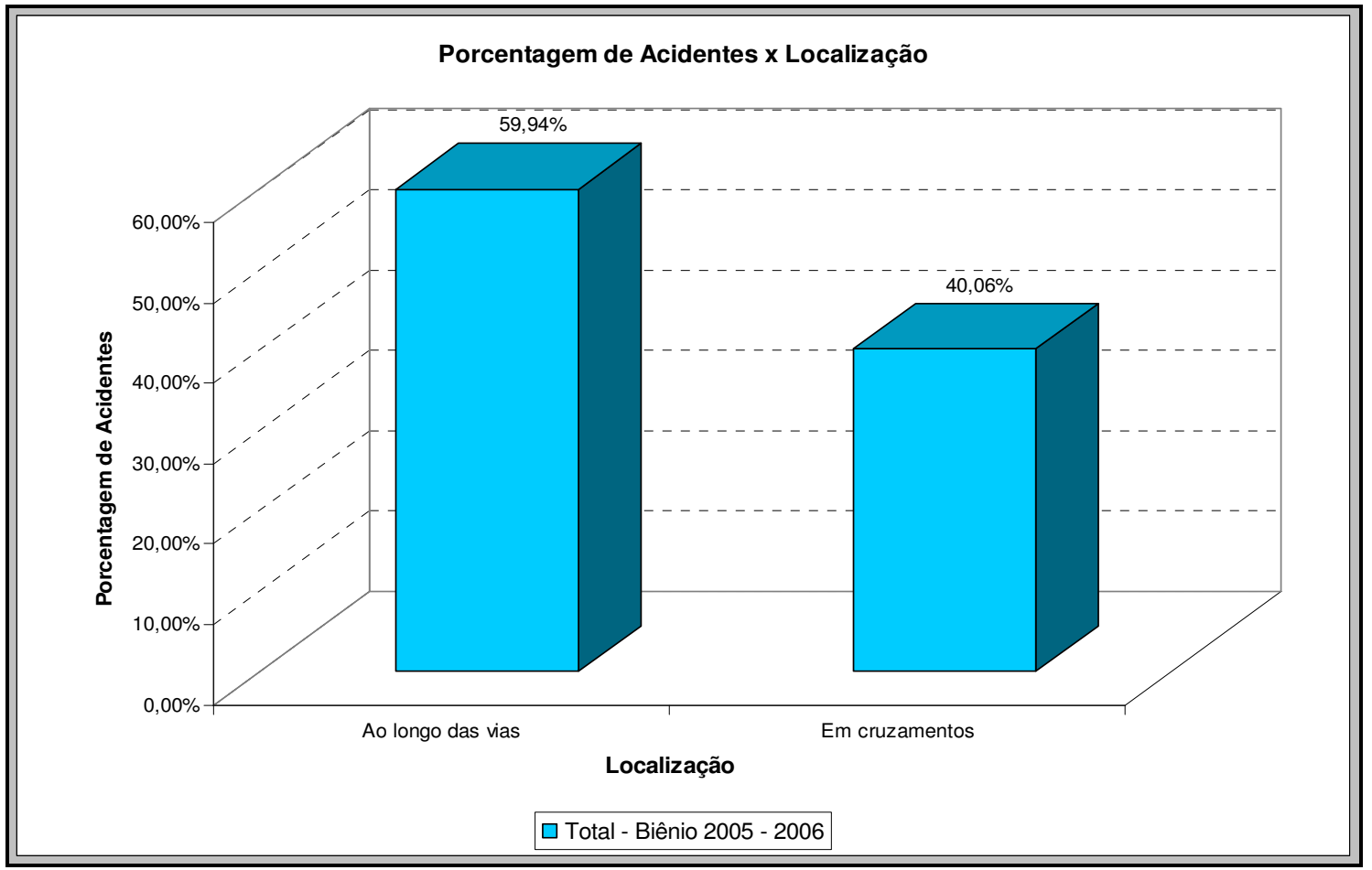

Figura 4.20: Porcentagem de acidentes de trânsito envolvendo o transporte coletivo de acordo com as condições meteorológicas considerando os tipos de acidentes.

A distribuição dos acidentes ocorridos ao longo das vias é visualizada na Figura 4.21. 


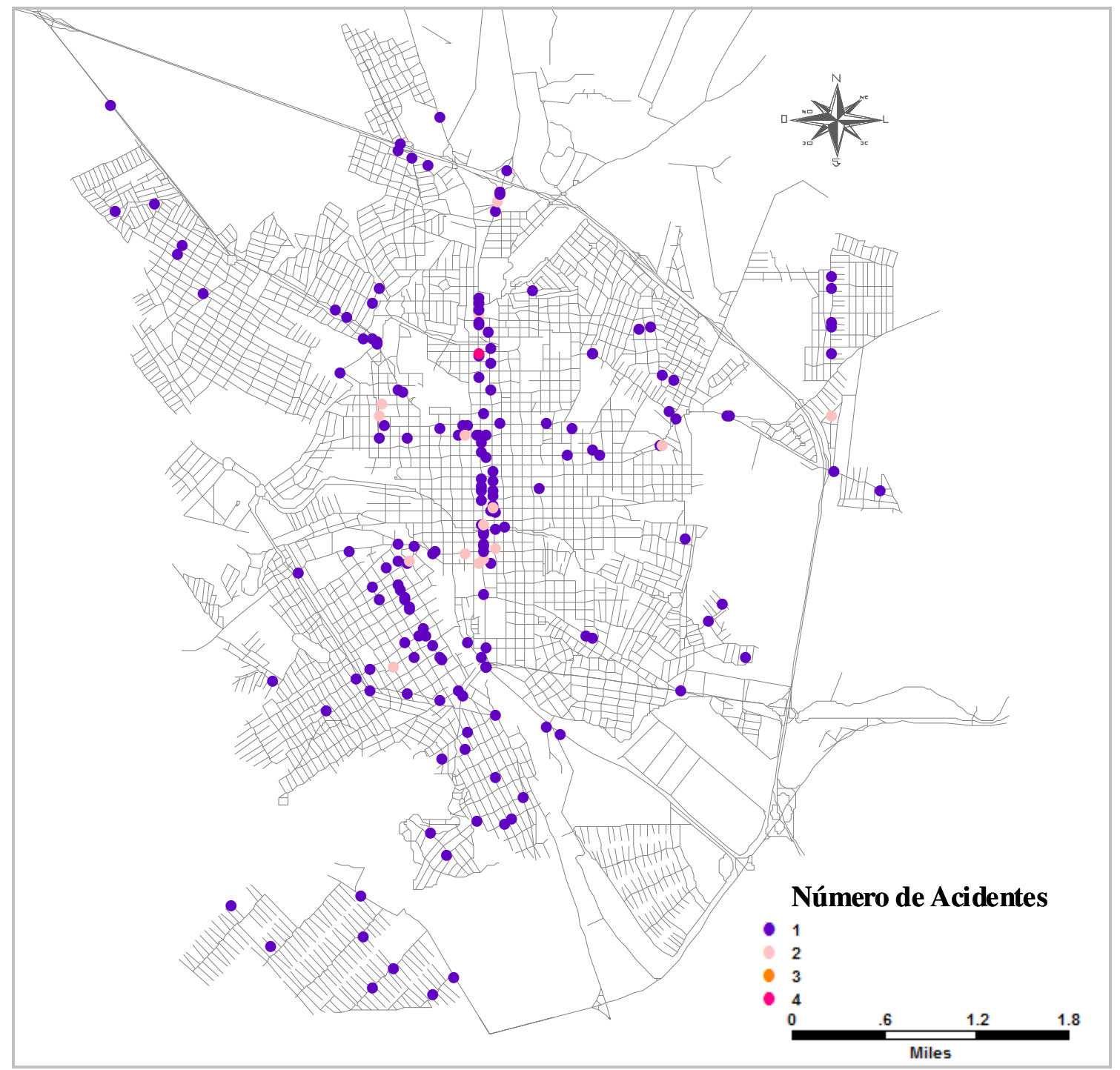

Figura 4.21: Mapa referente à distribuição espacial dos acidentes de trânsito ocorridos ao longo das vias no biênio 2005 - 2006.

A distribuição dos acidentes ocorridos em interseções é visualizada na Figura 4.22. 


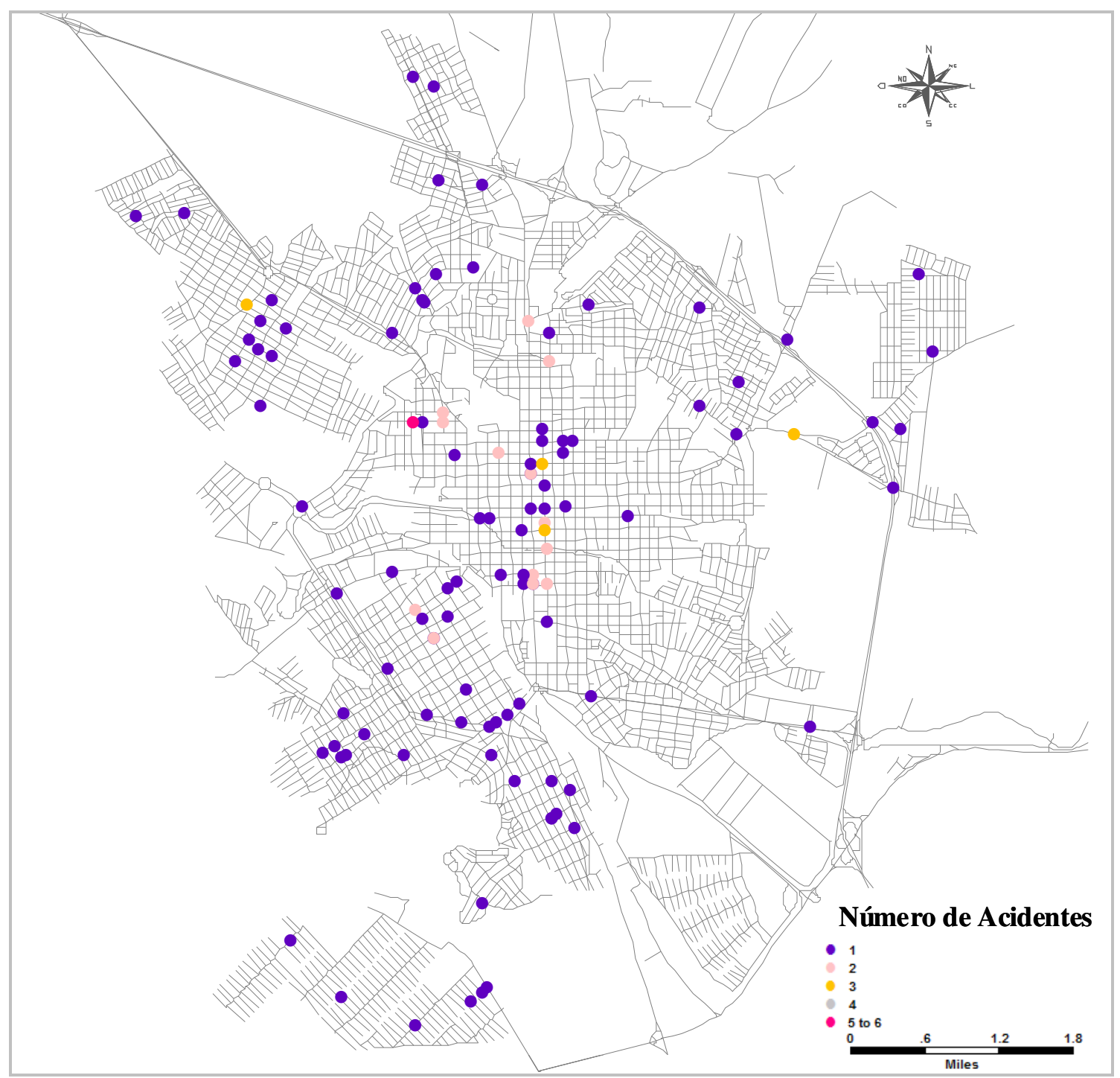

Figura 4.22: Mapa referente à distribuição espacial dos acidentes de trânsito ocorridos em interseções no biênio 2005 - 2006.

\subsubsection{Identificação de vias e locais críticos}

Na Tabela 4.16 e na Figura 4.23 estão relacionadas as vias que apresentaram um número absoluto mínimo de 3 acidentes envolvendo os veículos de transporte coletivo. 
Tabela 4.16: Vias com número absoluto mínimo de 3 acidentes

\begin{tabular}{lcccc}
\hline \multicolumn{1}{c}{ Vias } & $\begin{array}{c}\text { Total de } \\
\text { acidentes }\end{array}$ & $\begin{array}{c}\text { Danos } \\
\text { materiais }\end{array}$ & $\begin{array}{c}\text { Vítima não } \\
\text { fatal }\end{array}$ & Vítima fatal \\
\hline Av. São Carlos & 32 & 30 & 2 & 0 \\
Rua Dna Alexandrina & 15 & 13 & 2 & 0 \\
Av. Dr. Teixeira De Barros & 12 & 12 & 0 & 0 \\
Rua Quinze De Novembro & 7 & 7 & 0 & 0 \\
Av. Dr. Carlos Botelho & 6 & 5 & 1 & 0 \\
Rua Miguel Petroni & 6 & 6 & 0 & 0 \\
Av. João De Lourenço & 5 & 4 & 1 & 0 \\
Av. Prof. Luiz Augusto De Oliveira & 4 & 3 & 1 & 0 \\
Rua Walter De Camargo Schultzer & 4 & 4 & 0 & 0 \\
Rua Desemb. Julio De Faria & 4 & 4 & 0 & 0 \\
Av. Sallum & 4 & 4 & 0 & 0 \\
Rua Candido Padim & 3 & 1 & 2 & 0 \\
Rua Paulino Botelho De Abreu Sampaio & 3 & 2 & 1 & 0 \\
Rua Pe. Teixeira & 3 & 2 & 1 & 0 \\
Rua Sta. Cruz & 3 & 3 & 0 & 0 \\
\hline
\end{tabular}




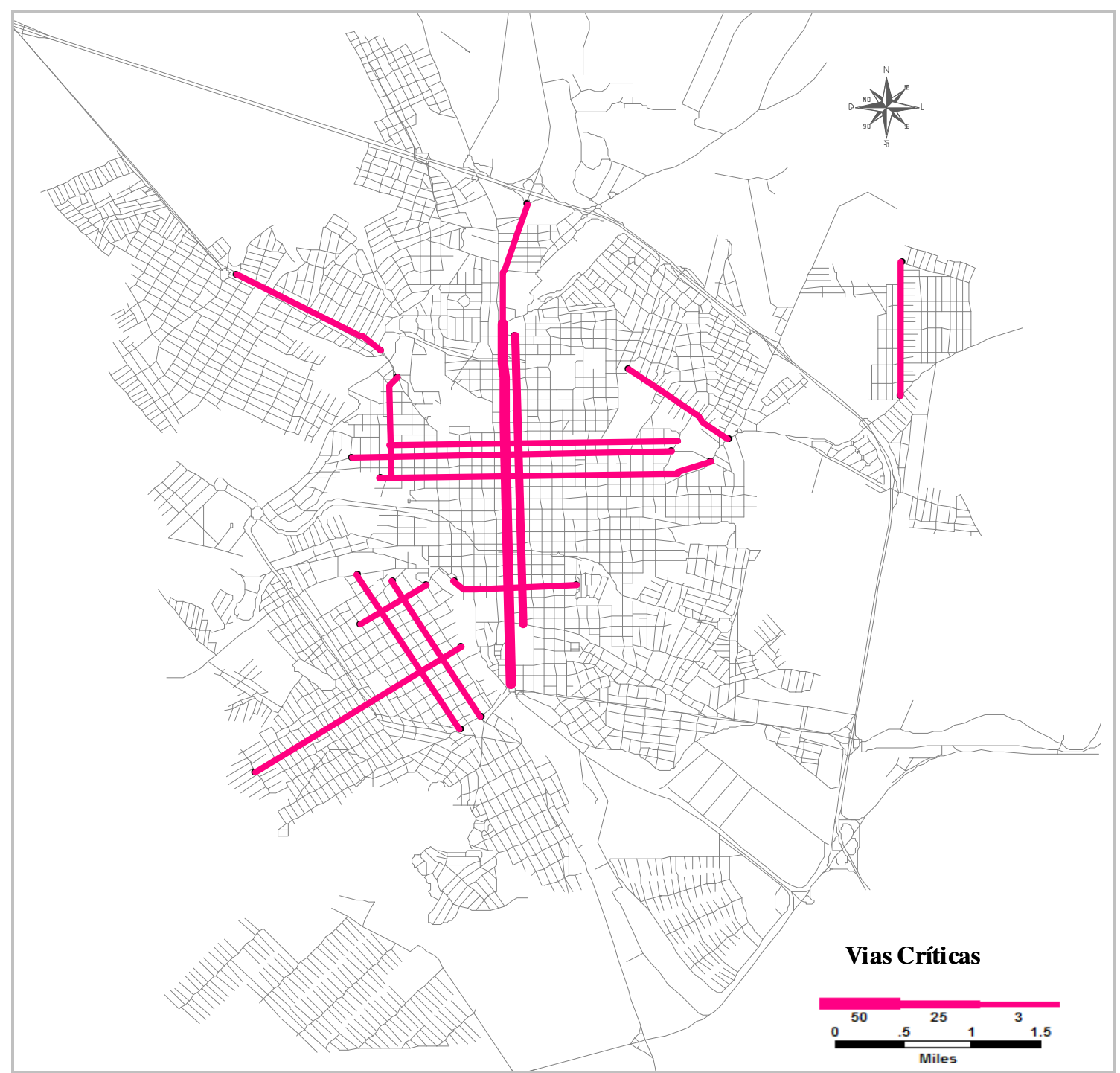

Figura 4.23: Mapa temático referente às vias de transporte coletivo com número absoluto mínimo de 3 acidentes.

Na Tabela 4.17 e na Figura 4.24 estão indicados os locais que apresentaram um número absoluto mínimo de 2 acidentes envolvendo os veículos de transporte coletivo. Esses locais são todas interseções. 
Tabela 4.17: Locais (interseções) com número absoluto mínimo de 2 acidentes.

\begin{tabular}{lcccc}
\hline \multicolumn{1}{c}{ Locais (Interseções) } & $\begin{array}{c}\text { Total de } \\
\text { acidentes }\end{array}$ & $\begin{array}{c}\text { Danos } \\
\text { materiais }\end{array}$ & $\begin{array}{c}\text { Vítima não } \\
\text { fatal }\end{array}$ & $\begin{array}{c}\text { Vítima } \\
\text { fatal }\end{array}$ \\
\hline Rua Maestro João Seppe x Rua Serafim Vieira De Almeida & 8 & 6 & 2 & 0 \\
Avenida Bruno Ruggiero x Rua Sebastião Sampaio Osório & 3 & 2 & 1 & 0 \\
Rua Dna Alexandrina x Rua São Sebastião & 3 & 3 & 0 & 0 \\
Rua Lourenco Inoccentini x Rua Dr Marino Da Costa Terra & 3 & 2 & 1 & 0 \\
Rua Treze De Maio x Rua Dna. Alexandrina & 3 & 2 & 1 & 0 \\
Avenida Sallum x Rua Ananias Evengelista De Toledo & 2 & 2 & 0 & 0 \\
Avenida Sallum x Rua Candido Padim & 2 & 2 & 0 & 0 \\
Avenida São Carlos x Rua Pe Teixeira & 2 & 1 & 1 & 0 \\
Avenida São Carlos x Rua Santa Cruz & 2 & 1 & 1 & 0 \\
Rua Eugênio de Andrade Egas x Avenida.São Carlos & 2 & 2 & 0 & 0 \\
Rua Bento Carlos x Avenida São Carlos & 2 & 1 & 1 & 0 \\
Rua Dna. Alexandrina x Rua Geminiano Costa & 2 & 2 & 0 & 0 \\
Rua José Bonifacio x Rua Quinze De Novembro & 2 & 0 & 1 & 1 \\
Rua Sta. Cruz x Rua Dna. Alexandrina & 2 & 1 & 1 & 0 \\
Rua Dna. Maria Jacinta x Rua Major Júlio Salles & 2 & 1 & 1 & 0 \\
Av. Trabalhador São Carlense x Rua São Joaquim & 2 & 0 & 2 & 0 \\
Rua Serafim Vieira De Almeida x Rua Mj. Júlio Salles & 2 & 2 & 0 & 0 \\
\hline
\end{tabular}




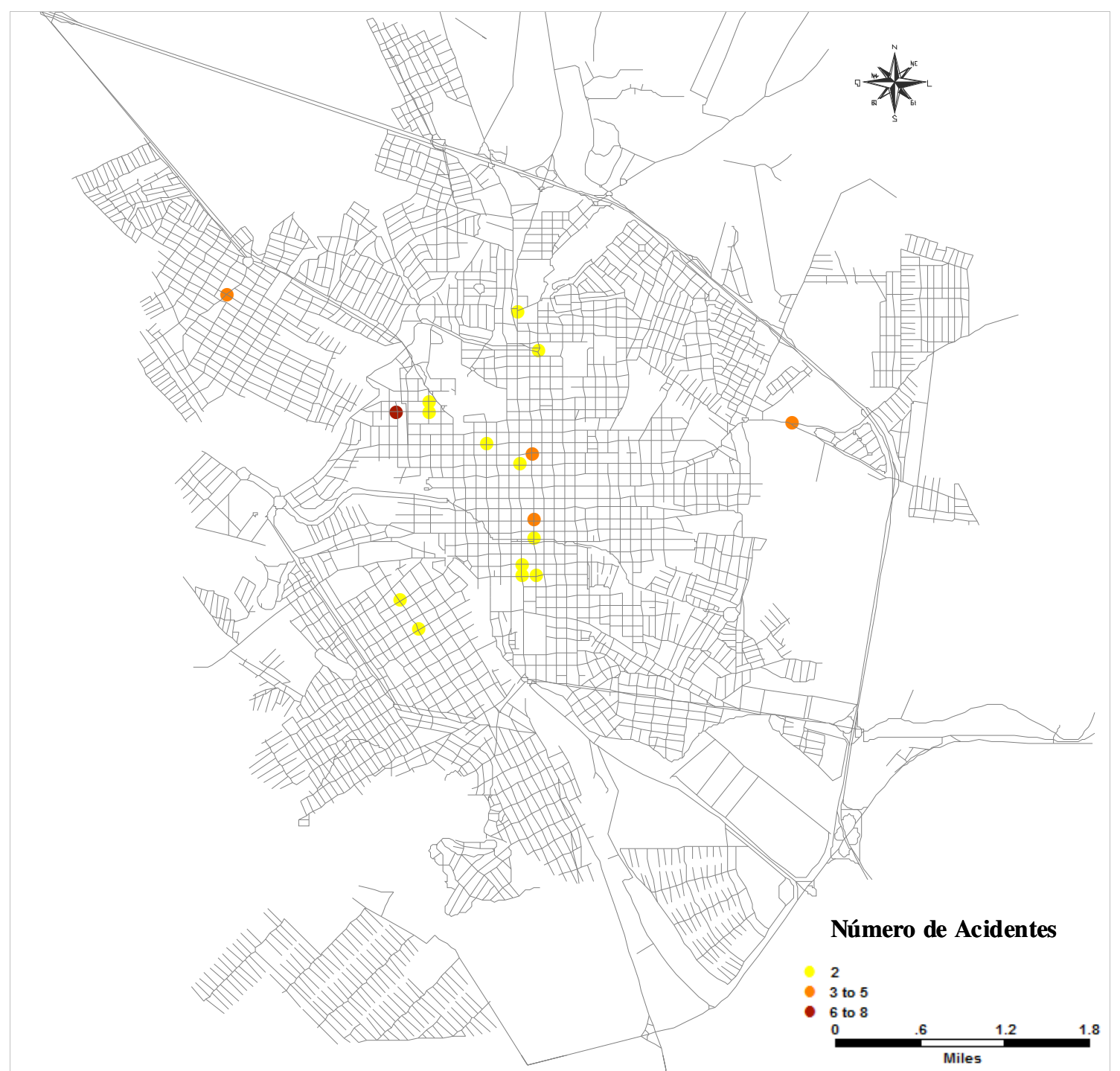

Figura 4.24: Mapa temático referente aos locais (interseções) com número absoluto mínimo de 2 acidentes. 


\section{5}

\section{DIAGNÓSTICO}

\subsection{TIPOS DE ACIDENTES}

De acordo com os dados apresentados no capítulo 4 (Tabela 4.2), relativo ao biênio 2005 - 2006, os acidentes dos tipos Colisão Transversal, Colisão Lateral, Colisão Traseira e Choque em Veículo Estacionado, representaram juntos 92,40\% do total de acidentes envolvendo o transporte coletivo. Os demais tipos de acidentes, Colisão Frontal, Queda de Passageiro, Atropelamento de Pedestre e Choque em Objeto Fixo, totalizam 7,60\% do total de acidentes.

Acidentes do tipo Colisão Transversal são caracterizados por envolverem veículos em direções perpendiculares, resultando em acidentes típicos de interseções. Os demais tipos de acidentes, Colisão Lateral, Colisão Traseira, Choque em Veículo Estacionado, Colisão Frontal, Queda de Passageiro, Atropelamento de Pedestre e Choque em Objeto Fixo ocorrem sobretudo, próximos aos pontos de parada, podendo ser considerados como acidentes típicos de meio de quadra.

Com relação à ocorrência de acidentes do tipo Colisão Lateral em pontos de parada do sistema de transporte coletivo, suas prováveis causas são semelhantes ao verificado no estudo realizado por Af. Wåhlberg (2002), uma vez que também ocorreram em virtude do pouco espaço destinado à acomodação dos ônibus e da ocorrência de carros estacionados próximos aos pontos de parada. 
De acordo com Mon - Ma (2005), as prováveis causas de ocorrência de Colisões Laterais nos pontos de parada, durante ações de embarque e desembarque, ou ao longo da via, podem ser atribuídos à:

- Má localização do ponto de parada, muito próximo da interseção, dificultando a percepção do motorista do outro veículo para o retorno do veículo de transporte coletivo para a faixa de rolamento; e,

- Desvio da atenção do motorista do veículo de transporte coletivo, por estar atento ao fluxo de tráfego da via principal não percebendo a ultrapassagem lateral do outro veículo.

Para as Colisões Traseiras, diferentemente do estudo de Af. Wåhlberg (2002) no qual este tipo de acidente envolveu ônibus-ônibus, devido à falta de treinamento dos motoristas, na cidade de São Carlos os veículo envolvidos foram automóvel (ou moto) - ônibus e ocorreram muito provavelmente devido à falta de atenção por parte dos condutores envolvidos ou devido à má localização dos pontos de parada.

Em pontos de parada o registro de acidentes do tipo Colisão Traseira também pode ser atribuído à elevada inclinação presente nas principais vias de transporte coletivo (Avenida São Carlos, Rua Dna. Alexandrina, Rua Miguel Petroni, Rua Raimundo Corrêa, Rua Desembargador Júlio de Faria, etc.). Esta inclinação, somada às características mecânicas do veículo e às características do carregamento, em muitos casos ocasiona um retorno (subida) ou avanço (descida) dos veículos para posterior início da marcha, ocorrendo os acidentes.

As causas de acidentes do tipo Choque em Veículo Estacionado podem estar atribuídas ao estacionamento irregular de veículos na via, comprometendo a execução de giros de curva dos ônibus de transporte coletivo, em decorrência da necessidade de sobre- 
largura destes para realizarem as conversões. Além disso, as operações de embarque ou desembarque repentino dos veículos ao longo das vias sem as devidas precauções, muitas vezes também contribui para a colisão entre os demais veículos e o ônibus de transporte coletivo.

O tipo de acidente classificado como Queda de Passageiro, o qual corresponde à queda de passageiros em operações de embarque/desembarque e também no interior do veículo, apresenta como prováveis causas freadas bruscas em decorrência do surgimento de situações de perigo e desatenção por parte dos motoristas, devido à falta de visibilidade ou devido ao cansaço, nas operações de embarque e desembarque, tal como verificado em Albertsson e Falkmer (2005).

Na cidade de São Carlos não há uma padronização dos modelos dos ônibus de transporte coletivo, uma vez que em muitos é verificado o embarque/desembarque de passageiros pela porta traseira e em outros pela porta dianteira. Isto ocorre devido às várias diferentes posições do Validador em relação ao layout do ônibus, utilizado para permitir a integração temporal, física e tarifária do sistema de transporte coletivo. De acordo com a posição do validador, há maior ou menor espaço disponível entre o cobrador e o condutor do veículo e maior distanciamento do cobrador em relação à porta traseira do veículo.

Especialmente naqueles veículos que apresentam embarque/desembarque pela porta traseira, muitas vezes em situações de lotação máxima (horário de pico) o cobrador e o motorista encontram dificuldades para a visualização dos passageiros que acomodaram-se nos degraus dos ônibus, procedendo ao fechamento das portas e início da marcha, provocando o acidente. 


\subsection{DISTRIBUICÃO TEMPORAL}

Verificou-se um maior número de acidentes de trânsito envolvendo os ônibus de transporte coletivo em dias úteis. Isto se deve ao fato de que durante a semana a frota operacional é maior em decorrência do maior volume de usuários, além de maior circulação de todos os tipos de veículos nas vias, em função das várias atividades comerciais, industriais e de serviços que produzem e atraem um grande número de viagens. Aos finais de semana, há uma redução no número da frota operacional diretamente relacionada com o menor número de atividades na cidade e, conseqüentemente, menor geração de viagens.

No período estudado, às sextas-feiras foi registrada a maior ocorrência de acidentes que resultaram em Vítimas Não Fatais em comparação aos demais dias da semana, o que pode ser explicado pelo maior volume de veículos e pedestres nas vias no período diurno (fluxo de saída da cidade) e menor volume no período noturno, maior consumo de álcool, maior desrespeito à sinalização, etc. Aos finais de semana foi registrado maior número de acidentes que resultaram em Vítimas Fatais, o que pode ser atribuído ao menor número de veículos circulando nas vias que estimulam o desenvolvimento de velocidades acima do permitido e propiciam maior distração e falta de atenção de motoristas e pedestres. Soma-se a esses fatores o maior consumo de álcool aos finais de semana.

\subsection{TIPOS DE ACIDENTES x PERÍODO DO DIA}

Com relação ao Período do Dia, considerando o total de acidentes em cada período de acordo com a gravidade, verificou-se uma diferença percentual muito pequena entre os períodos diurnos e noturnos com relação à ocorrência de acidentes de trânsito que resultaram 
em danos materiais, conforme dados da Tabela 4.8. O período noturno, embora tenha apresentado menor número de ocorrência de acidentes de trânsito em relação ao período diurno, proporcionalmente apresentou maior número de acidentes que resultaram em vítimas fatais e não fatais. Isto pode ser explicado pelo menor volume de tráfego contribuindo para que muitos condutores desenvolvam velocidade acima do permitido para a via, ocasionando acidentes.

Considerando a proporção de cada tipo de acidente em cada período, considerando dados da Tabela 4.9, no período diurno houve maior ocorrência de acidentes dos tipos Colisão Lateral, Colisão Traseira, Queda de Passageiro e Choque em Objeto Fixo, respondendo por 52,95\% de todos os acidentes ocorridos no período. Acidentes do tipo Colisão Transversal e Colisão Frontal, Choque em Veículo Estacionado e Atropelamento de Pedestre ocorreram proporcionalmente em maior número no período noturno sobre o período diurno, totalizando $68,58 \%$ de todos os acidentes ocorridos à noite.

O aumento da ocorrência no período noturno dos tipos de acidentes listados anteriormente pode estar atribuído sobretudo, às condições de visibilidade noturna aliadas à desatenção dos condutores envolvidos, desobediência à sinalização de parada obrigatória, falta de sinalização, ausência de fiscalização, etc.

Com relação às condições de visibilidade, de acordo com Gold (1998), em decorrência da pouca iluminação no período noturno, os condutores dos veículos apresentam dificuldades em observar o pedestre e este em avaliar com precisão a velocidade de deslocamento do veículo, gerando em muitos casos erros de avaliação, causando o acidente do tipo Atropelamento de Pedestre. 
$\mathrm{Na}$ cidade de São Carlos, a porcentagem de ocorrência dos acidentes tipo Atropelamento de Pedestre difere bastante do verificado em estudo da European Conference Of Ministers Of Transport - ECMT (2000), mesmo este considerando todos os tipos de veículos envolvidos. De acordo com este estudo, nos países europeus o período noturno concentrou a ocorrência de 51,00\% dos atropelamentos que resultaram em vítimas fatais e $29,00 \%$ do total de atropelamentos que geraram vítimas não fatais, sendo que para a cidade São Carlos no período noturno foi verificada maior ocorrência de atropelamentos que resultaram em vítimas não fatais $(66,67 \%)$ em comparação aos atropelamentos que resultaram em vítimas fatais $(33,33 \%)$. A diferença verificada entre os resultados obtidos pela ECMT e o presente trabalho, pode ser atribuída aos tamanhos diferentes da amostra de dados utilizada. Para a cidade de São Carlos foram utilizados dados referentes a dois anos, enquanto que no estudo supracitado utilizaram-se dados coletados ao longo de quatro anos de pesquisa, além de envolver vários países europeus.

Especificamente com relação ao acidente do tipo Queda de Passageiro (acidente típico das operações de transporte coletivo), ocorreu proporcionalmente em maior número no período diurno quando comparado ao período noturno, conforme dados da Tabela 4.9. Isto pode ser explicado, pelo fato de que no período diurno em decorrência do maior volume de tráfego nas vias e de passageiros, muitas linhas de transporte coletivo apresentaram atrasos operacionais e conseqüentemente, desenvolvimento de velocidade acima do permitido e maior ocorrência de freadas bruscas e acidentes. Além disso, em relação ao período noturno o período diurno apresenta maior número de passageiros transportados, inclusive idosos e crianças, os quais estão mais propensos a sofrerem este tipo de acidente, em função de suas características físicas. 


\subsection{DISTRIBUICÃO ESPACIAL}

Acidentes envolvendo os ônibus de transporte coletivo ocorreram em maior número ao longo das vias em relação às interseções. Isto pode ser explicado pela ocorrência de maior número de operações de embarque e desembarque ao longo da via, uma vez que há um maior número de pontos de parada localizado no meio da quadra. Além disso, cita-se também a provável falta de sinalização vertical e horizontal nesses pontos, o que requer atenção redobrada dos motoristas dos veículos que trafegam atrás de um veículo de transporte coletivo, como também o estacionamento de veículos próximos a esses pontos de parada.

Com relação aos acidentes ocorridos em interseções, independente da forma de controle presente, estes são caracterizados em sua maioria por envolverem veículos em direções aproximadamente perpendiculares que resultam em colisões transversais. Devido às características do acidente, um dos veículos envolvidos possui uma área neutra maior do que o outro veículo envolvido, isto é, uma maior área de proteção para com seus ocupantes. Esta área neutra corresponde à presença de maior "massa de proteção" que impede que o(s) ocupante(s) do veículo sofra(m) algum tipo de ferimento uma vez que o(s) protegem, tais como a parte frontal do veículo (capô) e a parte traseira (porta-malas). Na maioria dos casos, o outro veículo envolvido possui menor área neutra, uma vez que a face do veículo que sofrerá a colisão transversal será a face lateral (portas) e que apresenta menor proteção para com seus ocupantes. Em virtude desses detalhes, acidentes ocorridos em interseções podem apresentar um número maior de acidentes com vítimas do que os acidentes ocorridos ao longo das vias.

Em interseções também podem ocorrer acidentes do tipo colisão lateral que ocorre quando dois veículos que trafegam na mesma via e no mesmo sentido iniciam a conversão 
simultaneamente, culminando com a colisão exatamente no cruzamento. Isto ocorre porque muitas vezes um dos condutores dos veículos não percebe a presença do outro veículo, uma vez que este se encontra em um dos seus pontos de dificuldade de visibilidade ("pontos cegos"), o que torna a percepção do motorista muito limitada.

Conforme Figura 4.17, no biênio 2005 - 2006 os acidentes de trânsito envolvendo os ônibus de transporte coletivo apresentaram-se espalhados por todas as regiões da cidade, com maior concentração no eixo norte-sul, principalmente a região central, região sudoeste e região oeste.

Locais que apresentaram apenas um acidente de trânsito ocorreram em toda a mancha urbana da cidade de São Carlos, em muitos bairros com características distintas entre si. A ocorrência de dois acidentes de trânsito foi registrada, sobretudo no eixo norte-sul e nas proximidades da Santa Casa de Misericórdia de São Carlos, local este que atrai e produz grande número de viagens. Locais que apresentaram três ou mais acidentes registrados situaram-se em pontos diversos da cidade, sobretudo em vias importantes de ligação entre o bairro e o centro da cidade e que apresentam elevado volume de tráfego.

Na região sudeste da cidade de São Carlos verificou-se a menor ocorrência de acidentes de trânsito envolvendo os ônibus de transporte coletivo. Isto pode ser explicado pelo fato desta região apresentar um número reduzido de linhas de transporte coletivo em comparação às demais regiões da cidade, baixa demanda de usuários, localizar-se próximo ao centro comercial, etc.

Acidentes que resultaram em vítimas (fatais e não fatais) encontraram-se distribuídos por toda a mancha urbana principalmente nas regiões central, sudoeste e noroeste (notadamente nas proximidades da Santa Casa de Misericórdia de São Carlos), como visto na 
Figura 4.18. Nas demais regiões da cidade verificaram-se uma pequena ocorrência de acidentes que resultaram em vítimas, notadamente a região sudeste, como verificado anteriormente.

Com relação aos acidentes que resultaram em vítimas fatais, verificou-se que ocorreram em pontos distintos da cidade, conforme Figura 4.19, sendo uma ocorrência ao longo da via e três ocorrências em interseções. Concentraram-se a partir da região central em direção ao sul, englobando as regiões oeste, sudoeste e sudeste e vias perimetrais e coletoras, cujos limites de velocidade são iguais a $60 \mathrm{~km} / \mathrm{h}$, envolvendo veículos tipo automóvel, motocicleta, bicicleta e caminhão. Ocorreram durante dias úteis (terça-feira e sexta-feira) e aos domingos, no período noturno (uma ocorrência) e no período diurno (três ocorrências), sob condição meteorológica boa e operados com sinalização de parada obrigatória.

\subsubsection{Vias Críticas}

Com relação às vias críticas de ocorrência de acidentes de trânsito, de um total de 1.541 vias existente na cidade de São Carlos, 290 (18,82\%) são destinadas ao fluxo de ônibus de transporte coletivo, sendo que destas, $87(30,00 \%)$ apresentaram a ocorrência de acidentes de trânsito envolvendo o transporte público, ressaltando que em muitas vias o transporte público opera em alguns trechos e não em toda extensão. Muitas destas vias diferem entre si com relação à extensão e características próprias de composição e formas de controle do fluxo de tráfego, características de adensamento e uso do solo, conservação do pavimento, entre outras.

O número de acidentes envolvendo os ônibus de transporte coletivo ocorrido nas vias variou entre 1 e 32 para o biênio 2005- 2006 (ver Tabela 4.16). Nas vias que apresentaram apenas um registro de acidente de trânsito no período em estudo, o acidente pode ser 
considerado um evento esporádico, uma vez que ocorreu apenas uma vez em 730 dias e sua causa pode ser atribuída a diversos fatores distintos.

Conforme dados apresentados no item 4.3.2, as vias críticas de ocorrência de acidentes de trânsito localizam-se em toda a malha viária da cidade de São Carlos e praticamente em todas as regiões, à exceção da região sul. Essas ruas e avenidas correspondem às principais vias do transporte coletivo da cidade e das regiões em que se encontram, apresentando elevada freqüência de ônibus de transporte coletivo por hora e grande volume de tráfego, em decorrência de características de uso misto do solo, gerando muitas viagens.

Das 15 vias críticas apresentadas (Ver Tabela 4.16), seis estiveram localizadas na região central, três na região sudoeste, duas na região noroeste, uma na região norte e duas na região nordeste. Tal como verificado em Gold (1998), houve maior concentração de acidentes de trânsito na área central, em decorrência da maior concentração de atividade de comércio e de serviço, o que não significa que as condições de trânsito nesta região sejam mais perigosas que nas demais regiões da cidade, mas sim que há um volume elevado de veículos e de pedestres.

Analisando detalhadamente a Avenida São Carlos, via com maior número de acidentes de trânsito (via mais crítica), foram verificadas muitas colisões do tipo lateral nas conversões à direita em trechos de faixa exclusiva. Tal como verificado em Ferraz e Torres (2004), este tipo de prioridade ao transporte coletivo apresenta a desvantagem de dificultar a conversão à direita dos demais veículos do tráfego, como também exige constante fiscalização para evitar invasões e estacionamentos irregulares. 
Nesta via também se verificou a ocorrência de muitas colisões no momento em que o ônibus de transporte coletivo efetuava a troca de faixa de rolamento, em determinados trechos, tal como visualizado na Figura 5.1.

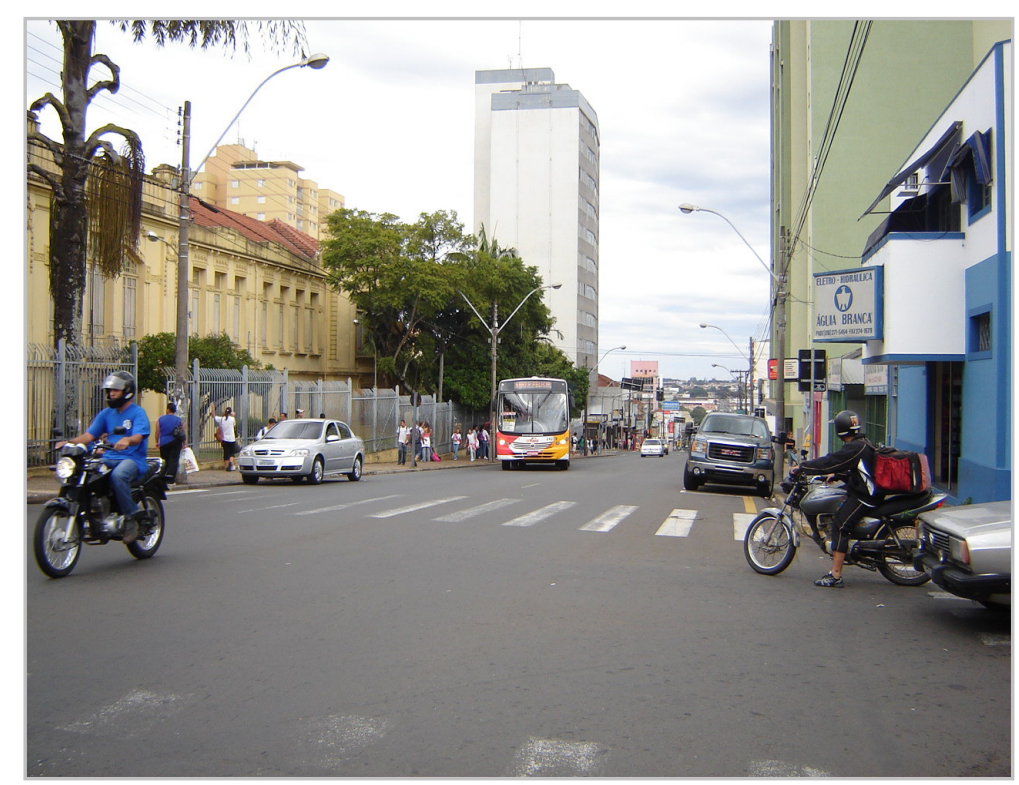

Figura 5.1: Primeira via mais crítica - Avenida São Carlos

Esta situação pode estar condicionada a dois fatores:

- Criação de regiões de entrelaçamento em virtude da necessidade dos ônibus de transporte coletivo cruzarem o fluxo para convergirem à esquerda, principalmente nas proximidades da Avenida Dr. Carlos Botelho;

- Realização de manobras junto a estacionamentos no meio fio, conflitando com o fluxo da via no momento de entrada do veículo de transporte coletivo na faixa de rolamento;

Com relação à Rua Dona Alexandrina, verificou-se a predominância de colisões traseiras, notadamente quando os ônibus de transporte coletivo encontravam-se estacionados nos pontos de parada efetuando embarque/desembarque. Embora nesta via não haja a implantação de faixa exclusiva em nenhum trecho, o lado direito da via consolidou-se como 
um corredor de ônibus no qual não é permitido o estacionamento de veículos, contribuindo para o fluxo constante dos ônibus de transporte coletivo. A Figura 5.2 mostra um trecho da Rua Dona Alexandrina.

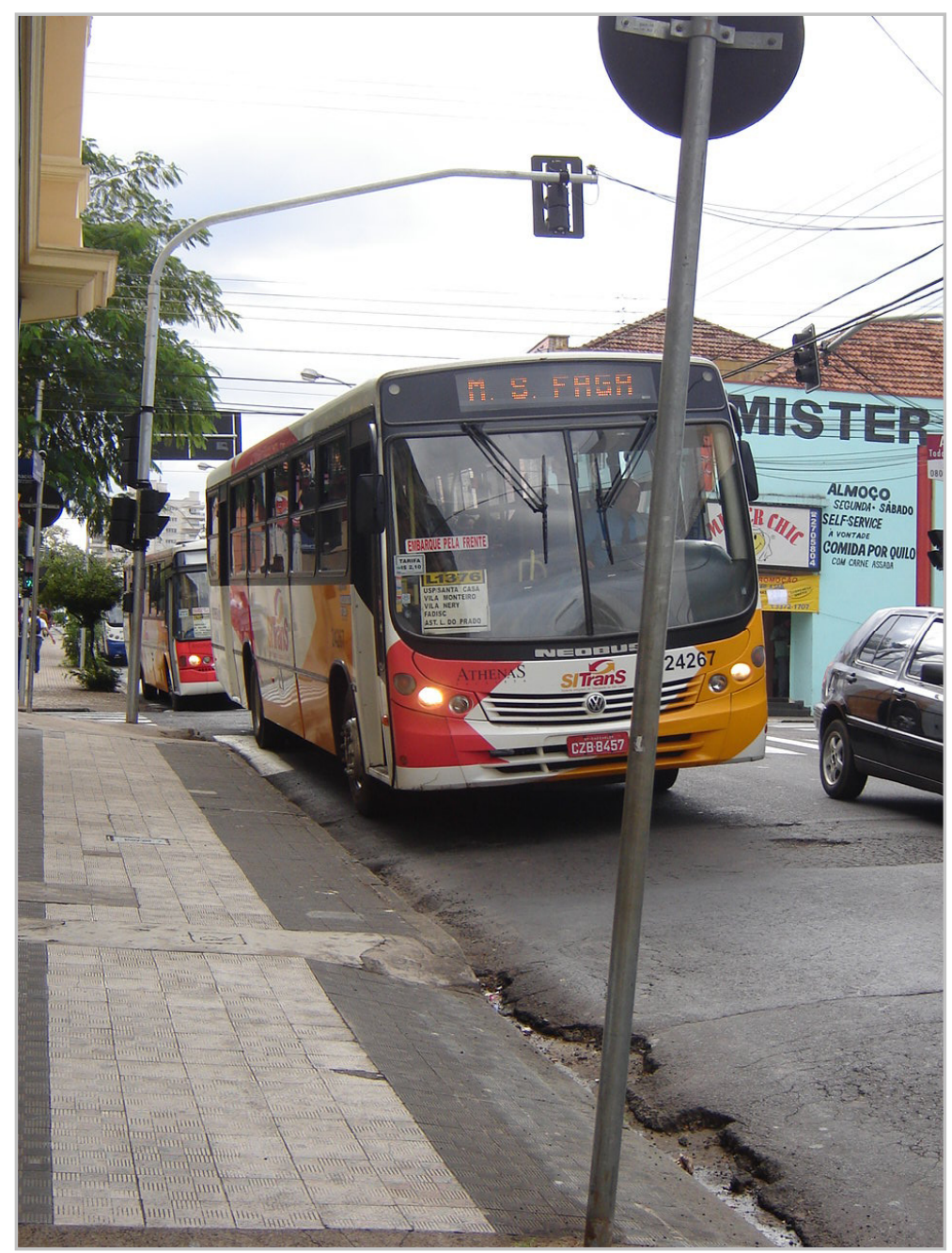

Figura 5.2: Segunda via mais crítica - Rua Dona Alexandrina

Em todas as vias críticas, foram verificadas muitas colisões entre os ônibus de transporte coletivo e veículos que saíam de estacionamentos localizados juntos ao meio fio, além de choques com veículos estacionados cujos condutores desembarcavam do veículo sem tomar as devidas precauções com relação ao fluxo da via. 
Verificou-se ainda a ocorrência de acidentes em conversões à direita em trechos sem faixa exclusiva. Tal ocorrência se deve ao pequeno raio de giro de muitas esquinas nas quais o condutor do ônibus precisa de mais espaço para acomodar a sobre-largura do ônibus ao efetuar a conversão à direita, não observando o outro veículo que, concomitantemente, realiza a conversão forçando a passagem. Nesta situação, muitas vezes o veículo envolvido localizase em um ponto cego de visibilidade em relação ao condutor do ônibus, causando o acidente.

A ocorrência de colisões traseiras ao longo das vias críticas pode ser atribuída ao acentuado declive no sentido do fluxo, ao o alto volume de tráfego, à velocidade relativamente elevada, à inexistência de sinalização horizontal nos pontos de parada, etc.

\subsubsection{Interseções Críticas}

No tocante aos acidentes ocorridos em interseções, a ocorrência variou entre 1 e 8 . Tal como considerado para as vias críticas, interseções que apresentaram a ocorrência de somente um registro de acidente, o mesmo pode ser considerado um evento esporádico.

As interseções críticas localizaram-se principalmente no eixo norte-sul, regiões sudoeste, oeste, nordeste e leste, nas principais vias do transporte coletivo da cidade de cada região, envolvendo vias de categoria arterial, coletora e local.

De um total de 137 acidentes ocorridos em interseções, 106 (77, 37\%) ocorreram em interseções controladas com sinal de parada obrigatória PARE, 16 (11,68\%) em interseções com nenhum tipo de controle, $12(8,76 \%)$ em interseções semaforizadas, e $3(2,19 \%)$ em interseções com outra forma de controle (sinalização horizontal, tachões, canalização,etc.).

Diferentemente do verificado em Yan et al. (2005) e em Mon-Ma (2005) que observaram acidente do tipo Colisão Traseira como o mais freqüente, na cidade de São Carlos 
em interseções semaforizadas, foi constatado maior número de Colisões Transversais $(58,33 \%$ do total de colisões ocorridas em semáforos), seguidas de Colisões Laterais (33,33\% do total) e Colisões Traseiras (8,33\% do total). Ressalta-se que nos estudos dos autores supra-citados, foram analisados acidentes de trânsito envolvendo todos os tipos de veículos e não somente ônibus de transporte coletivo.

Principalmente nas interseções entre uma via secundária com única faixa e uma via preferencial com dois sentidos de tráfego separados por canteiro central, muitas vezes o sinal de parada obrigatória PARE não é respeitado, passando a operar como dê a preferência, causando o acidente. Além da desobediência à sinalização, o problema também está associado às características geométricas desfavoráveis do canteiro central que muitas vezes não apresenta adequada capacidade de armazenagem do fluxo da via secundária.

Em outros casos, em decorrência do alto volume da via transversal, o condutor do ônibus inicia a marcha avançando sobre o cruzamento e, conseqüentemente, sobre o fluxo da via transversal, com o objetivo de conseguir uma pequena brecha (gap) na travessia. Muitas vezes este avanço extrapola os limites do cruzamento avançando o fluxo e ocasionando o acidente.

Em todas as interseções críticas consideradas, de acordo com dados do BDAT, verificou-se que a principal causa da ocorrência destes acidentes foi o desrespeito à sinalização de parada obrigatória na via secundária. As demais causas podem estar relacionadas à: desobediência de sinalização semafórica, proximidade entre o ponto de parada e a interseção, ausência de sinalização de parada obrigatória, problemas de visibilidade, desrespeito às conversões preferenciais à direita da via, infra-estrutura da via (existência de valetas de drenagem, buracos, etc.), avanço de árvores na faixa de rolamento, esta última 
obrigando o condutor do veículo de transporte coletivo desviar para outra faixa, causando o acidente.

A primeira interseção mais crítica (com maior número de acidentes) - Rua Maestro João Seppe x Rua Serafim Vieira De Almeida - localiza-se em uma região constituída de vários pólos de serviços de saúde, além de núcleos residenciais e educacionais, gerando muitas viagens ao longo do dia e, conseqüentemente, elevado volume de tráfego. É formada por uma via coletora (Rua Maestro João Seppe) e uma via local (Rua Serafim Vieira De Almeida).

A interseção é do tipo simples com 04 (quatro) aproximações e as vias se interceptam aproximadamente perpendiculares formando um ângulo entre $70^{\circ}$ e $110^{\circ}$. Ambas as vias apresentam sentido duplo de direção, dando origem a 28 pontos de conflitos, potenciais pontos para a ocorrência de acidentes. Nesta interseção, sendo a Rua Maestro João Seppe uma via preferencial (tráfego de 12 linhas de transporte coletivo), todo o fluxo de veículos que trafega pela Rua Serafim Vieira de Almeida (via secundária) é controlado através da implantação de sinalização vertical e horizontal de parada obrigatória. Na via preferencial o estacionamento é regulamentado apenas em um dos lados da via e na via secundária, nos dois lados. Na Figura 5.3 é vista a primeira interseção mais crítica. 


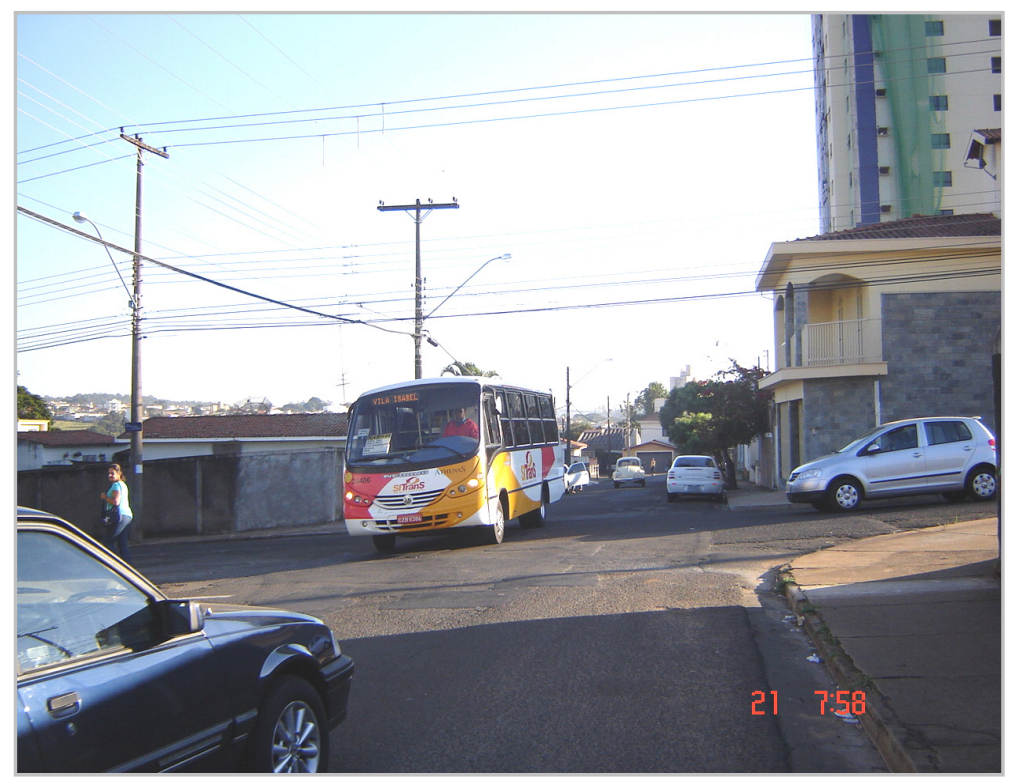

Figura 5.3: Primeira interseção mais crítica - Rua Serafim Vieira de Almeida x Rua Maestro João Seppe

Todos os acidentes ocorridos nesta interseção concentraram-se no período diurno e durante todo o dia, em todos os intervalos horários e envolveram, além dos ônibus de transporte coletivo, somente veículos do tipo automóvel. De acordo com o banco de dados, a ocorrência de acidentes nesta interseção pode ser atribuída a problemas de visibilidade, má disposição e visibilidade da sinalização de trânsito existente, desobediência à sinalização, elevado fluxo de veículos, etc.

Analisando o fluxo de tráfego nas proximidades da interseção em estudo, verifica-se que a Rua Serafim Vieira de Almeida concentra elevado fluxo proveniente da Rua Paulino Botelho de Abreu Sampaio, em virtude de sua localização, como já dito anteriormente. O sentido do elevado fluxo de veículos pode ser explicado por dois fatores:

- Diante da demanda por estacionamento nem sempre atendida, muitos motoristas que trafegam pela Rua Paulino Botelho de Abreu Sampaio realizam o retorno à mesma através da Rua Serafim Vieira de Almeida e procuram fazê-lo de forma mais rápida possível, muitas vezes desrespeitando a sinalização de parada obrigatória; e, 
- A Rua Serafim Vieira de Almeida é uma das vias que possibilita o escoamento do fluxo de tráfego de toda esta região e a única que possibilita o acesso direto à região do Shopping Center;

Com relação à segunda interseção crítica, Avenida Bruno Ruggiero Filho x Rua Sebastião Sampaio Osório, localiza-se em uma região predominantemente residencial e com presença de estabelecimentos comerciais, sendo formada por uma via arterial (Avenida Bruno Ruggiero Filho) e uma via coletora (Rua Sebastião Sampaio Osório).

A Avenida Bruno Ruggiero Filho apresenta dois sentidos de tráfego separados por canteiro central e duas faixas de rolamento em cada sentido, com estacionamento regulamentado do lado direito da via e constitui-se em uma via preferencial. A Rua Sebastião Sampaio Osório apresenta sentido único de circulação, uma faixa de rolamento, e estacionamento regulamentado dos dois lados da via e é classificada como via secundária. As vias se interceptam aproximadamente perpendiculares formando um ângulo entre $70^{\circ} \mathrm{e} 110^{\circ} \mathrm{e}$ a travessia do cruzamento é realizada em duas etapas.

Em virtude do fluxo de ônibus de transporte coletivo trafegar pela Rua Sebastião Sampaio Osório e necessitar cruzar a Avenida Bruno Ruggiero Filho, em cada etapa necessária para transpor a via são encontrados 3 pontos de conflito. Neste local o canteiro central não apresenta condições geométricas para a armazenagem do fluxo de ônibus proveniente da Rua Sebastião Sampaio Osório, o que muitas vezes induz seu condutor a realizar a transposição do cruzamento em uma única etapa. Em outros casos, o condutor realiza a parada junto ao canteiro central, entretanto não consegue evitar que o veículo que trafega pela Avenida Bruno Ruggiero Filho colida na parte traseira do ônibus, por, em algumas vezes, estar trafegando em alta velocidade. Na Figura 5.4 é vista a segunda interseção crítica. 


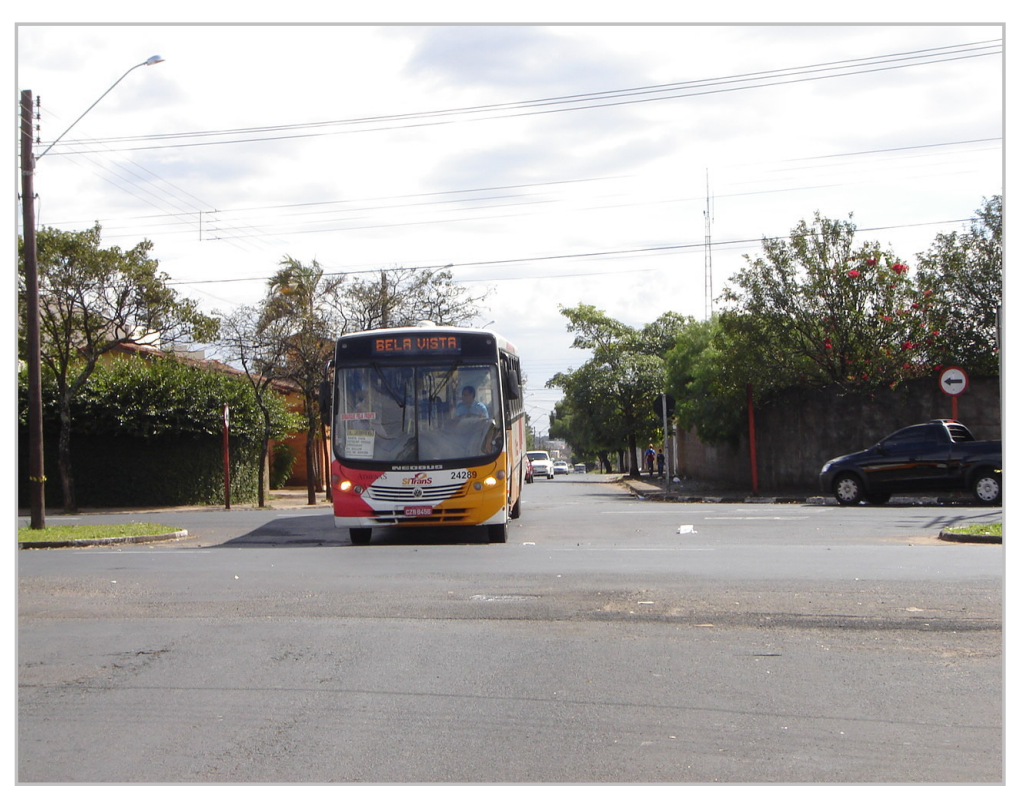

Figura 5.4: Segunda interseção crítica - Rua Sebastião Sampaio Osório x Avenida Bruno Ruggiero Filho

Todos os acidentes ocorridos nesta interseção concentraram-se no período diurno e ao longo do dia, em todos os intervalos horários e envolveram, além dos ônibus, veículos do tipo automóvel e moto. De acordo com o banco de dados, os acidentes ocorridos neste local foram causados pelo desrespeito à sinalização aliada a problemas geométricos da via, sinalização existente, despreparo dos condutores, etc.

Independentemente do local de ocorrência dos acidentes de trânsito, após a caracterização dos fatores contribuintes à ocorrência de acidentes, é necessário caracterizar as medidas corretivas necessárias para a redução e, se possível, eliminação da probabilidade de novas ocorrências do mesmo tipo. Para tanto, é necessário identificar um conjunto de ações de engenharia que possam reduzir consideravelmente a ocorrência de outro acidente similar aos ocorridos anteriormente em determinado local, mesmo tendo conhecimento sobre a importância do fator humano sobre o caso em questão (MINISTÉRIO DOS TRANSPORTES, 2002). 


\section{6}

\section{PROPOSICÃO DE ACÕES MITIGADORAS}

Especificamente no tocante à ocorrência de acidentes de trânsito envolvendo os ônibus de transporte coletivo, a redução do número de ocorrências depende não somente do poder público, através de intervenções nas áreas de Engenharia (emprego de medidas preventivas ou corretivas que envolvam planejamento urbano e engenharia de tráfego), Educação (conscientização, treinamento e capacitação dos condutores, etc) e Esforço Legal (contingente policial treinado, disponibilidade de viaturas e equipamentos, aplicação de penalidades severas, etc.) (FERRAZ E RAIA JR, 2005); depende também do operador do sistema de transporte através da implantação de programas de orientação e treinamento dos condutores dos veículos.

Estas ações podem ser empregadas em dois níveis: $i$ ) caráter geral, implementadas pelo poder público e empresa operadora; e, ii) caráter específico, implementada pelo poder público e direcionada aos pontos críticos de acidentes de trânsito envolvendo os ônibus de transporte coletivo.

\subsection{AÇÕES MITIGADORAS DE CARÁTER GERAL}

No âmbito do poder público, as seguintes ações mitigadoras de caráter geral são propostas: 
- Implantação e/ou melhoria da sinalização horizontal e vertical nos cruzamentos críticos de ocorrência de acidentes de trânsito;

- Poda adequada das árvores para evitar: i) a necessidade de mudança de faixa de rolamento devido ao avanço da arborização nas vias; e, $i$ ) problemas de visibilidade nos cruzamentos;

- Nas interseções, quando necessário, eliminação de movimentos de conversão de um ou de todos os movimentos;

- Realocação de pontos de parada localizados muito próximos ao início ou fim de uma interseção;

- Proibição de estacionamento nas aproximações de determinados cruzamentos, com o objetivo de melhorar a visibilidade;

- Ampliação dos raios de curva em determinadas interseções, eliminando o avanço do transporte coletivo no fluxo contrário;

- Fiscalização ao longo dos pontos de parada nas principais vias de transporte coletivo, de forma a evitar o estacionamento irregular dos demais veículos da frota operante;

- Melhoria nas condições de iluminação em vias de tráfego de transporte coletivo, principalmente nas proximidades dos pontos de parada;

- Instalação de equipamento medidor de velocidade (fixo, estático, móvel ou portátil) nas principais vias críticas de acidentes de trânsito, de modo a coibir velocidades excessivas e inadequadas às características das vias; 
- Manutenção constante da pavimentação das vias de transporte coletivo, reduzindo a ocorrência de imperfeições que podem levar à ocorrência de acidentes; e,

- Realização e divulgação de campanhas educacionais voltadas para a conscientização dos condutores de automóveis sobre a preferência do fluxo do transporte coletivo nas principais vias da cidade, além do respeito às sinalizações horizontal (proibição de estacionamento) e vertical (localização dos pontos de parada).

No âmbito da empresa operadora, as seguintes ações mitigadoras de caráter geral são propostas:

- Aprimoramento do processo de treinamento e preparação dos novos condutores de ônibus de transporte coletivo, bem como do processo de reciclagem dos condutores mais antigos, envolvendo noções de direção defensiva, ações de segurança no trânsito e prevenção de acidentes;

- Implantação de um sistema de controle de velocidade dos veículos de transporte coletivo, através do bloqueio da velocidade operacional do veículo ao atingir a velocidade máxima regulamentada para a via e bloqueio do início da marcha caso o veículo encontre-se com as portas abertas; e,

- Aprimoramento da manutenção preventiva da frota de ônibus, de forma a evitar a ocorrência de acidentes de trânsito causados por problemas mecânicos. 


\subsection{AÇÕES MITIGADORAS DE CARÁTER ESPECÍFICO PARA O LOCAL MAIS CRÍTICO}

Após visita “in loco”, para a interseção mais crítica do biênio 2005-2006 foram relatados os diversos problemas encontrados e sugeridas ações mitigadoras com o objetivo de reduzir o número de acidentes de trânsito envolvendo os veículos de transporte coletivo.

\section{- Interseção mais crítica: Rua Maestro João Seppe x Rua Serafim Vieira De}

\section{Almeida}

A visita "in loco" da interseção mais crítica foi realizada em 2008, mesmo assim, as condições de geometria e de sinalização permanecem as mesmas do período em estudo (2005 - 2006), uma vez que não foi efetuada nenhuma alteração por parte do órgão gestor.

A interseção mais crítica é composta de duas vias de mão dupla, dando origem à formação de 28 pontos de conflito, como verificado na Figura 6.2. 


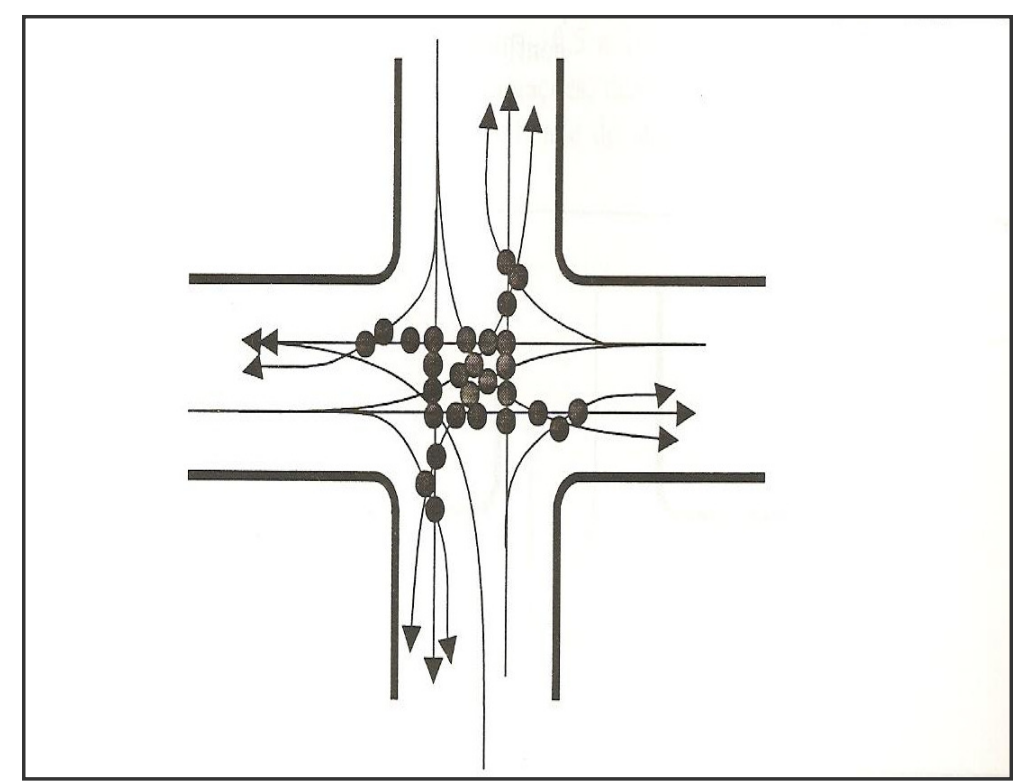

Figura 6.1: Pontos de conflito existentes na interseção Rua Maestro João Seppe x Rua Serafim Vieira de Almeida.

Fonte: Ferraz, Fortes e Simões (1999).

A situação atual da interseção é visualizada na Figura 6.3. 


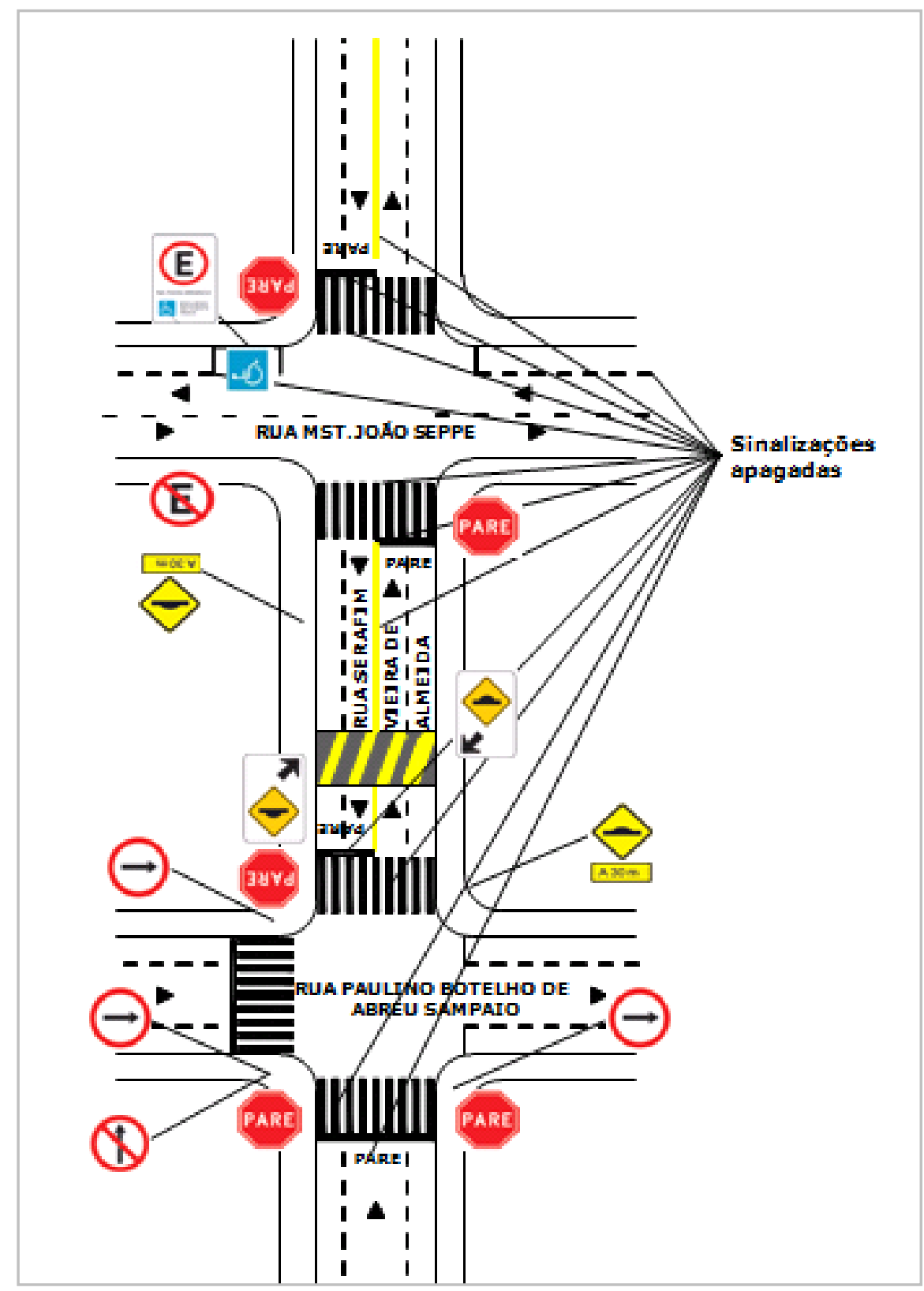

Figura 6.2: Croqui da interseção mais crítica - Rua Maestro João Seppe x Rua Serafim Vieira de Almeida

A situação atual da interseção, no tocante à sinalização e à geometria pode ser vista nas Figuras 6.4 à 6.7. 


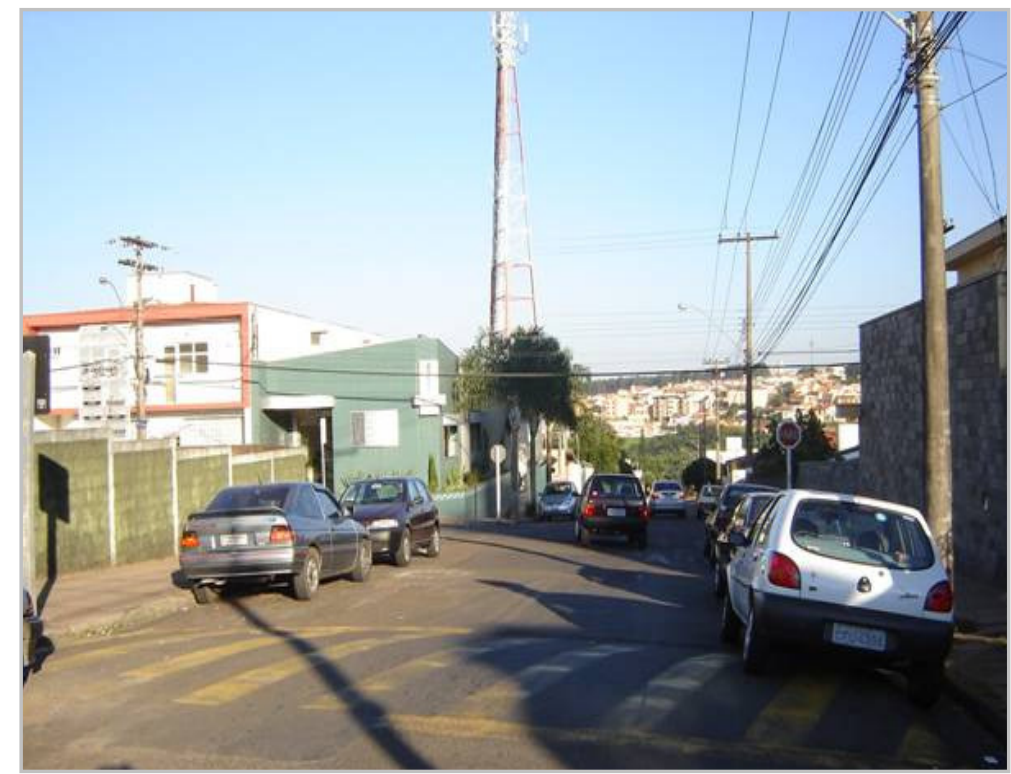

Figura 6.3: Interseção mais crítica - Rua Serafim Vieira de Almeida x Rua Maestro João Seppe - Vista da Rua Serafim Vieira de Almeida (sentido Santa Casa $\rightarrow$ Shopping Iguatemi)

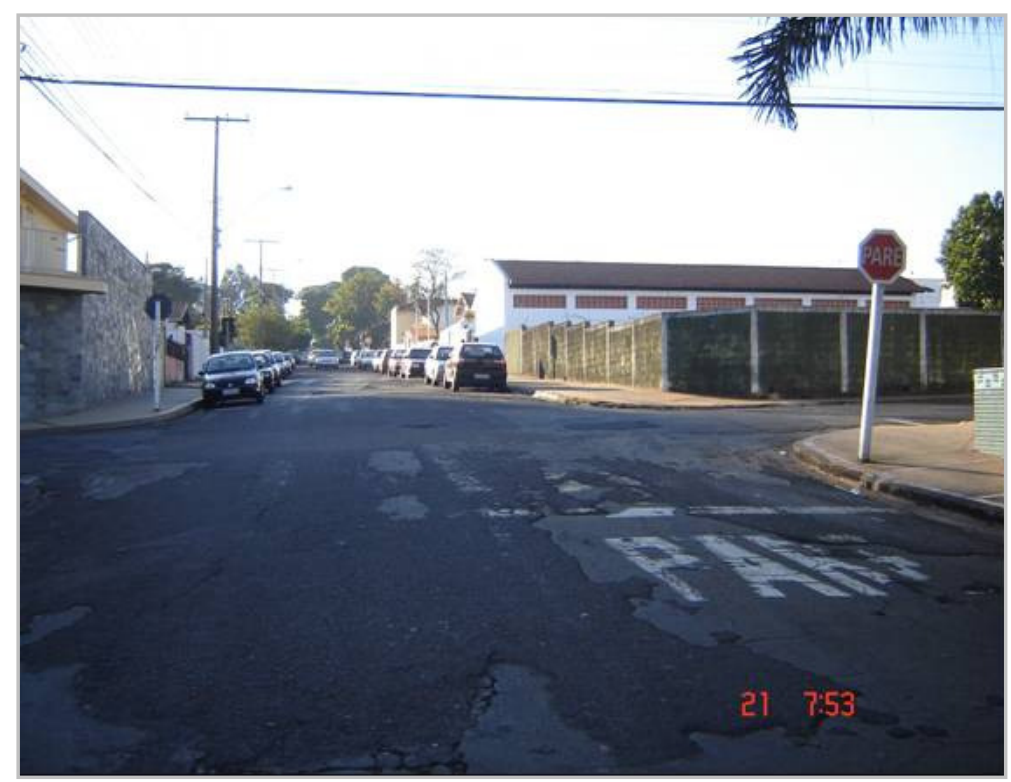

Figura 6.4: I Interseção mais crítica - Rua Serafim Vieira de Almeida x Rua Maestro João Seppe - Vista da Rua Serafim Vieira de Almeida (sentido Shopping Iguatemi $\rightarrow$ Santa Casa) 


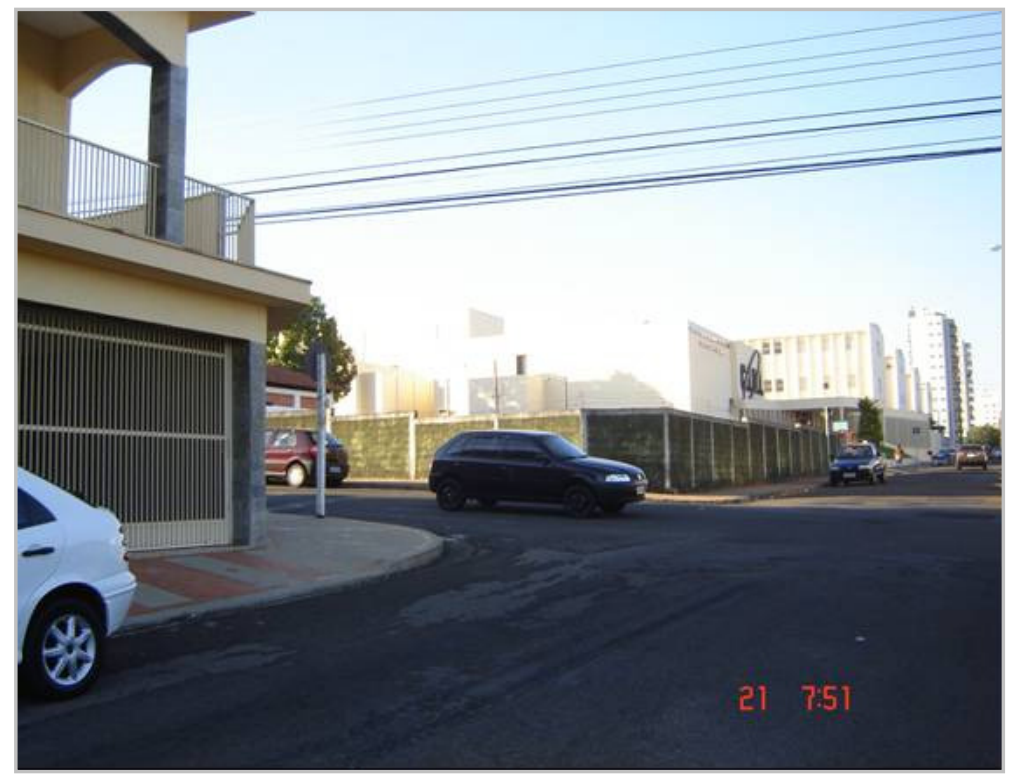

Figura 6.5: Interseção Rua Serafim Vieira de Almeida x Rua Maestro João Seppe - Vista da Rua Maestro João Seppe (sentido Rua Miguel Petroni $\rightarrow$ Rua XV de Novembro)

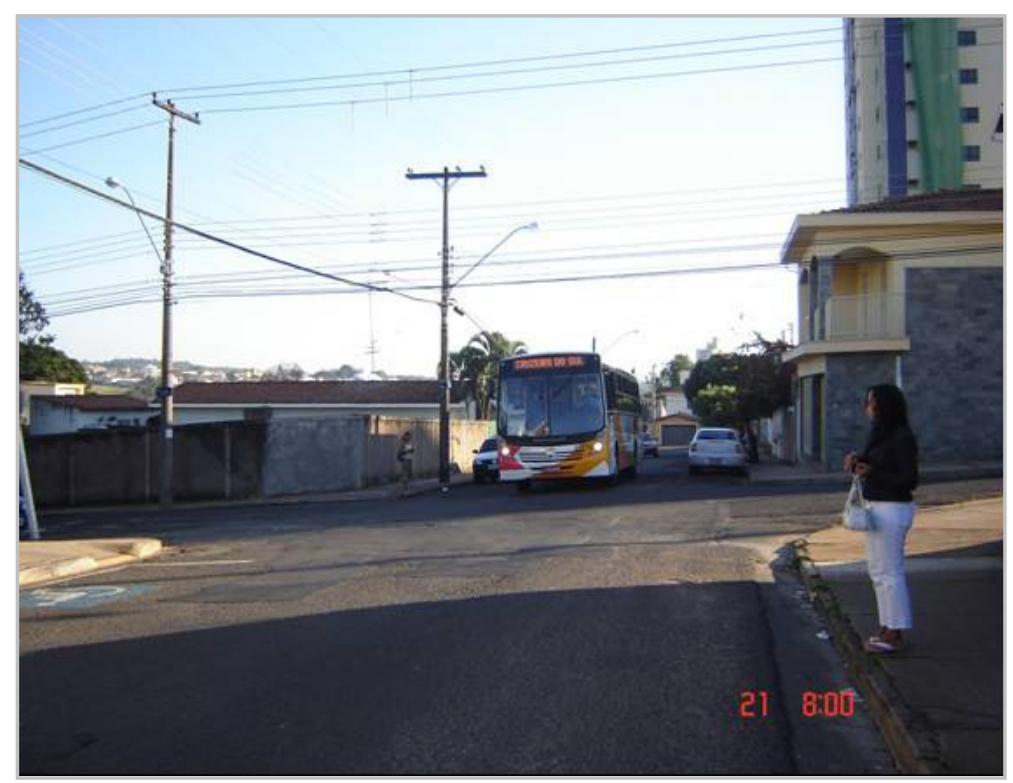

Figura 6.6: Interseção Rua Serafim Vieira de Almeida x Rua Maestro João Seppe - Vista da Rua Maestro João Seppe (sentido Rua XV de Novembro $\rightarrow$ Rua Miguel Petroni) 
Após visita "in loco" da interseção e com base nos fundamentos apresentados pelo Conselho Nacional de Trânsito - CONATRAN (2007), os principais problemas encontrados foram os seguintes:

- Sinalização horizontal parcialmente apagada;

- Desrespeito à sinalização de proibição de estacionamento na Rua Maestro João Seppe entre a Rua Serafim Vieira de Almeida e Rua XV de Novembro;

- Legenda PARE está a 1,20 m da faixa de retenção, portanto em desacordo com as normas oficiais;

- Inexistência de sinalização de velocidade máxima permitida, anterior à lombada;

- Inexistência de placa indicativa de saliência ou lombada à frente; e

- Desalinhamento na geometria horizontal.

Com o objetivo de reduzir o número de acidentes no local mais crítico, as seguintes ações:

- Implantação de um binário formado pela Rua Maestro João Seppe (via de mão única) e Rua Paulino Botelho de Abreu Sampaio (via de mão única), reduzindo o número de pontos de conflito para 10, como visto na Figura 6.8. 


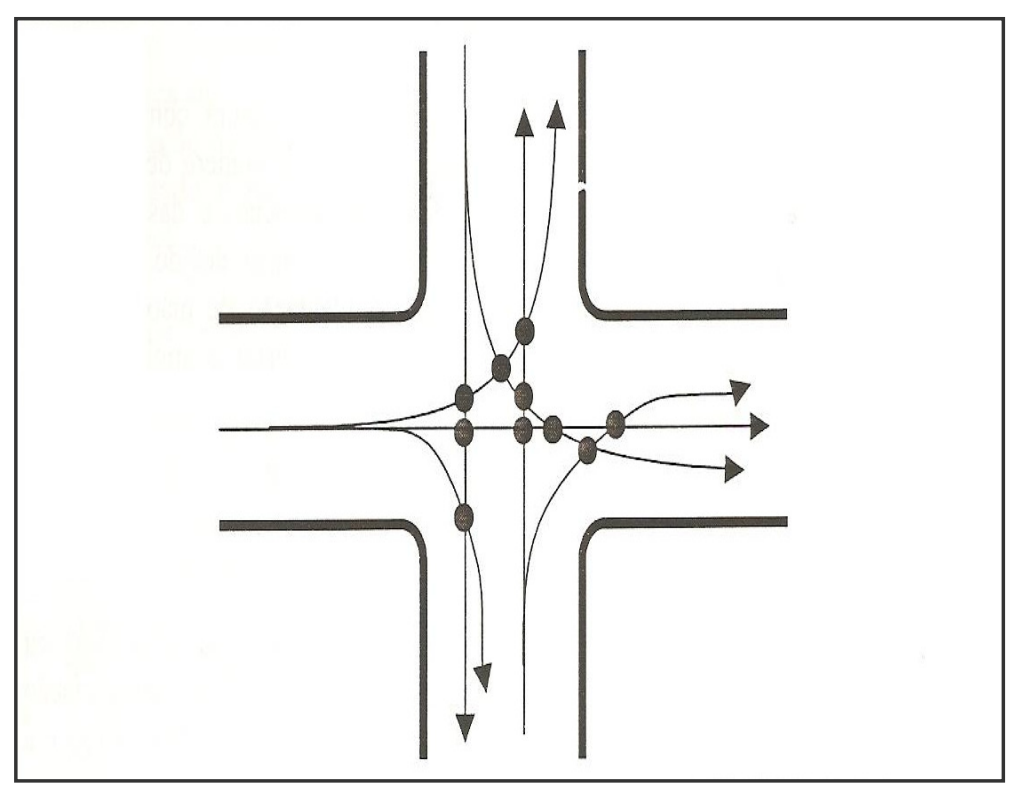

Figura 6.7: Pontos de conflito existentes para a nova configuração da interseção Rua Maestro João Seppe x Rua Serafim Vieira de Almeida. Fonte: Ferraz, Fortes e Simões (1999)

- Reforço da sinalização horizontal;

- Implantação de operação de fiscalização de trânsito mais ostensiva;

- Pintura de setas de direção no pavimento próximas à interseção;

- Correção da localização das sinalizações que estão em desacordo com as normas oficiais;

- Implantação de sinalização de velocidade máxima permitida e de placa indicativa de saliência ou lombada à frente;

Com base nas ações mitigadoras propostas para a interseção mais crítica, na Figura 6.9 é visualizado o croqui proposto para o local em questão. 


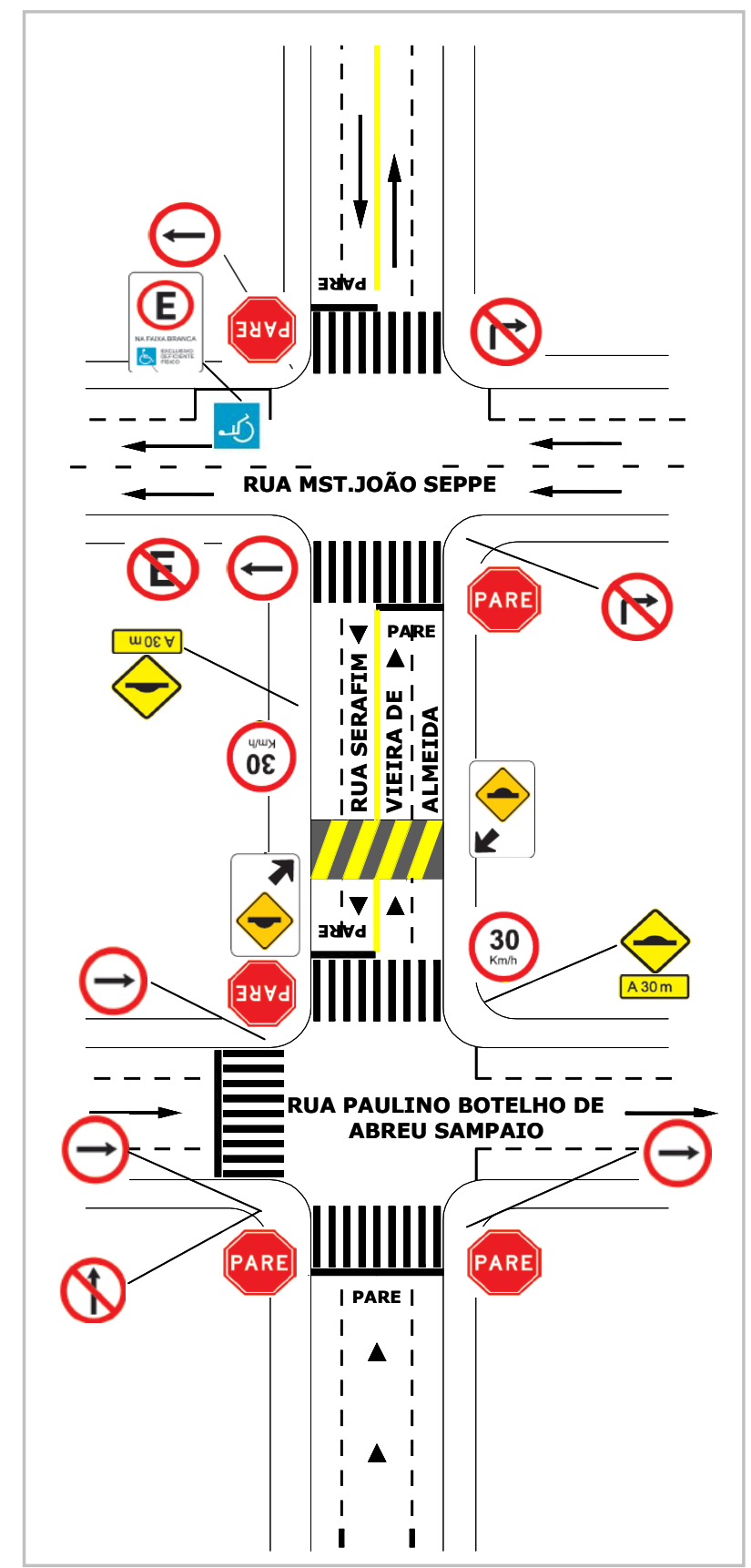

Figura 6.8: Croqui proposto para a interseção Rua Maestro João Seppe x Rua Serafim Vieira de Almeida 


\section{7}

\section{CONSIDERACÕES GERAIS}

\subsection{PRINCIPAIS CONCLUSÕES}

Nos últimos anos, os acidentes de trânsito têm-se constituído um verdadeiro desafio para as autoridades responsáveis pela segurança viária, uma vez que em muitos casos gera lesões irreversíveis em seus envolvidos e grande impacto sobre a economia dos países.

Notadamente com relação aos acidentes de trânsito envolvendo os ônibus de transporte coletivo, a preocupação com segurança viária torna-se ainda maior, em virtude da grande capacidade de transporte deste modo, podendo vir a vitimar dezenas de vidas. Uma forma de entender a ocorrência desses acidentes é coletando e analisando as suas informações contidas em Boletins e/ou Registros de Ocorrência (BO'S/RO'S).

Especificamente neste estudo, em alguns casos os BO'S/RO'S não se mostraram uma fonte totalmente confiável para o entendimento da ocorrência dos acidentes de trânsito, uma vez que não foi possível visualizar o croqui referente à disposição dos veículos envolvidos logo após o acidente e obter os relatos dos envolvidos nos acidentes. Através deste croqui e dos relatos dos envolvidos seria possível um melhor entendimento do acidente em si como da provável causa que o ocasionou.

Diante desta situação, o "Relatório de Ocorrência" de acidentes de trânsito utilizado pela empresa operadora mostrou-se eficaz para o melhor entendimento da ocorrência dos acidentes por sempre apresentar o croqui referente à disposição dos veículos logo após a 
ocorrência dos acidentes, como também informações adicionais sobre o acidente e a existência ou não de sinalização no local.

O Banco de Dados de Acidentes de Trânsito (BDAT) desenvolvido para a cidade de São Carlos mostrou-se prático e de fácil entendimento para a inserção dos dados de acidentes e deficitário para a especificação dos veículos envolvidos. Caso sejam analisados dados de acidentes referentes aos anos anteriores, será de extrema dificuldade a identificação dos ônibus de transporte coletivo uma vez que não há nenhum campo destinado à especificação do tipo de serviço prestado por esses veículos (transporte coletivo urbano, transporte suburbano, transporte escolar e transporte rodoviário), gerando grandes erros de análise dos dados. Ressalta-se que em alguns trechos das principais vias de transporte coletivo da cidade de São Carlos, é verificado o tráfego conjunto de ônibus de transporte coletivo, suburbano, escolar e rodoviário, dificultando ainda mais a discriminação dos veículos envolvidos.

Com o objetivo de melhorar a identificação dos acidentes de trânsito envolvendo os ônibus de transporte coletivo, sugerem-se algumas alterações no BDAT. Primeiramente, a inserção de um campo para especificar o tipo de serviço prestado pelos ônibus de transporte. A segunda alteração seria a inserção de um campo destinado aos dados dos ônibus de transporte coletivo, tais como prefixo, linha em que opera, carregamento no momento do acidente, sentido de operação (bairro - centro ou centro - bairro). Por fim, a inserção de dados referentes às características geométricas e ao volume de tráfego da via, ao limite de velocidade regulamentada, à habilitação e ao estado de embriaguez do condutor, etc, também seriam pertinentes.

O georreferenciamento dos acidentes de trânsito envolvendo os ônibus de transporte coletivo mostrou-se eficaz para a visualização da distribuição espacial dos mesmos. Os acidentes encontraram-se espalhados por todas as regiões da cidade, notadamente na região 
central, em virtude da característica diametral das linhas de transporte coletivo o que leva a uma concentração de ônibus na área central, como também em decorrência do elevado volume de veículos e pedestres e elevado declive. Também se verificou a ocorrência de acidentes nas regiões sul e oeste, regiões com características próprias de uso e ocupação do solo e que possuem importantes vias de transporte coletivo.

Para a cidade de São Carlos, estudo de caso deste trabalho, verificou-se a ocorrência de praticamente todos os tipos de acidentes envolvendo o ônibus de transporte coletivo, sendo o acidente do tipo Colisão Transversal o registrado em maior número.

Em muitos casos foi verificada a ocorrência de acidentes do tipo Colisão Lateral e Colisão Traseira em pontos de parada, cujas prováveis causas estão diretamente ligadas à falta de preparo dos condutores envolvidos, desrespeito e falta de sinalização, inclinação das vias e à necessidade de implantação de um sistema integrado de trânsito e transporte coletivo. Com relação a este último, um sistema integrado permitiria um adequado planejamento das paradas de ônibus (evitando locá-las próximas às interseções), compatibilizando-as com os estacionamentos regulamentados e proibidos, com a distância de caminhada entre os pontos e com a presença de estabelecimentos comerciais, residenciais e de serviços; possibilitaria a priorização do transporte coletivo em alguns trechos; execução de vias com raios de giro adequados à sobre-largura dos ônibus de transporte coletivo nas conversões, etc.

A falta de padronização da frota de ônibus de transporte coletivo, nos quais é permitido o embarque tanto pela porta traseira como pela porta dianteira, também se mostrou como uma provável causa da ocorrência dos acidentes de trânsito classificados como Queda de Passageiro. Especialmente nos casos de embarque/desembarque pela porta traseira, a dificuldade de visibilidade que o cobrador e o motorista apresentam para visualizarem os usuários que se encontram nos degraus dos veículos, em muitos casos, leva à ocorrência de 
acidentes. Uma solução para este problema seria a adoção de um layout único através da mudança do Validador para uma posição fixa em todos os veículos, mais próxima da porta traseira, requerendo investimentos da empresa operadora com a conseqüente redução do tipo de acidente vinculado a este problema.

As prováveis causas da ocorrência de acidentes de trânsito envolvendo os ônibus de transporte coletivo englobaram um conjunto de fatores, como: $i$ ) má localização dos pontos de parada; ii) estacionamento de carros muito próximos aos pontos de parada; iii) desvio de atenção dos condutores envolvidos; iv) problemas de visibilidade na interseção; v) desobediência à sinalização de parada obrigatória, dentre outros.

Este quadro demonstra a necessidade crescente de um conjunto de ações mitigadoras cujo participante não seja somente o Poder Público, responsável pela gestão do sistema, mas também o operador, de tal forma que as três áreas responsáveis pela redução da ocorrência e severidade dos acidentes - Engenharia, Educação e Esforço Legal - estejam integradas na junção dos dois atores responsáveis pelo sistema de transporte coletivo.

Através da cooperação entres os dois atores e baseando-se na redução dos acidentes calcada nas três áreas descritas anteriormente, é possível implementar ações mitigadoras de caráter geral. Estas ações compreendem desde manutenção da sinalização viária, melhoria na geometria, adoção de gabarito vertical das árvores até campanhas educativas para a redução dos acidentes, treinamento da mão de obra operante, uso de novas tecnologia veiculares, etc. Diante da necessidade de junção dos dois atores e muitas vezes, de procedimentos burocráticos para tal, o resultado das ações pode ser obtido em períodos de médio a longo prazo, postergando em um pequeno intervalo de tempo, os benefício de sua implantação. 
Junto ao Poder Público é possível realizar ações mitigadoras de caráter específico, através da identificação dos tipos de acidentes mais recorrentes, identificação das prováveis causas e medidas corretivas para a redução dos mesmos, como também através do tratamento das vias e pontos críticos de acidentes. O resultado das ações de caráter específico podem ser obtidos em curto prazo, uma vez que há apenas um ator envolvido e, em muitas vezes, as medidas corretivas não requerem grandes investimentos, como o sugerido para o cruzamento crítico (reforço e correção da localização da sinalização).

Através da implantação de um sistema de transporte coletivo eficiente, que pode ser considerada como uma ação mitigadora de caráter geral, muitos indivíduos que atualmente utilizam veículos particulares para efetuar seus deslocamentos na cidade, poderiam ser atraídos para o transporte público, reduzindo a frota de veículos presente nas vias. Esta redução, além de potencialmente ocasionar a redução do número de acidentes, aumentando consideravelmente a segurança viária na cidade de São Carlos, traria diversos ganhos para toda a população e não apenas àqueles usuários do sistema de transporte coletivo: $i$ ) redução de diversos custos associados aos acidentes de trânsito (humanos, econômicos e sociais); ii) redução da poluição atmosférica; ìii) redução de grandes investimentos de recursos públicos na infra-estrutura viária; iv) ajuste da velocidade operacional dos ônibus de transporte coletivo, reduzindo os atrasos operacionais; v) maior eficiência das cidades; etc.

Por fim, o aumento da segurança viária proveniente de um conjunto de ações de caráter geral e específico, resultaria em um grande ganho na sustentabilidade econômica da cidade, possibilitando aos seus habitantes uma melhor qualidade de vida e a formação de uma cidade mais humana. 


\subsection{SUGESTÕES PARA TRABALHOS VINDOUROS}

Como sugestão para trabalhos futuros, propõe-se a utilização de um período de estudo mais amplo, de tal forma que possa ser acompanhado o comportamento dos acidentes de trânsito envolvendo os ônibus de transporte coletivo ao longo dos anos, com relação à gravidade, tipo, distribuição temporal e espacial; bem como a utilização de ferramentas computacionais que possibilitem uma análise mais aprofundada dos acidentes de trânsito.

Além disso, para o mesmo intervalo de estudo, comparar os tipos de acidentes mais freqüentes envolvendo os ônibus de transporte coletivo com os tipos de acidentes mais freqüentes envolvendo a frota em geral, possibilitando assim identificar se há padrão de ocorrência de acidentes de trânsito envolvendo o transporte coletivo.

Sugere-se também analisar e caracterizar mais detalhadamente os acidentes de trânsito causados pelos condutores de transporte coletivo, levantando-se dados referentes à jornada e escala de trabalho, condições de trabalho, etc.

A análise conjunta dos dados de acidentes com dados sobre mobilidade da cidade de São Carlos, adensamento populacional das áreas da cidade, influência da hierarquia das vias na ocorrência de acidentes, uso e ocupação do solo, dentre outros dados que possam contribuir para o entendimento da ocorrência de acidentes de trânsito envolvendo os ônibus de transporte coletivo e, desta forma, implementar ações mitigadoras para a redução máxima destes acidentes, também são importantes para a realização de uma análise mais apurada dos acidentes de trânsito envolvendo os ônibus de transporte coletivo. 


\section{8}

\section{REFERÊNCIAS BIBLIOGRÁFICAS}

ABDEL-ATY; M.; RADWAN; E.; YAN, X. Characteristics of rear-end accidents at signalized intersections using multiple logistic regression model. Accident Analysis and Prevention, v. 37, n6, p. 983-995. mai. 2005.

ABNT - ASSOCIAÇÃO BRASILEIRA DE NORMAS TÉCNICAS. NBR - 10.697: Pesquisa de Acidentes de Trânsito: Terminologia. Rio de Janeiro, 1989.

ABNT - ASSOCIAÇÃO BRASILEIRA DE NORMAS TÉCNICAS. NBR - 12.898: Relatório de acidente de trânsito (RAT). Rio de Janeiro, 1993.

AF. WÅHLBERG, A.E. Characteristics of low speed accidents with buses in public transport. Accident Analysis and Prevention, v. 34, n. 5, p. 637-647, 2002.

AF. WÅHLBERG, A.E. Characteristics of low speed accidents with buses in public transport: part II. Accident Analysis and Prevention, v. 36, n. 1, p. 63-71, 2004.

ALBERTSSON,P.; FALKMER,T. Is there a pattern in European bus and coach incidents? A literature analysis with especial focus on injury causation and injury mechanisms. Accident Analysis and Prevention, v. 37, n. 2, p. 225-233, 2005.

ANTENUCCI, J. C.; BROWN, K.; CROSWELl, P. L.; KEVANY, M. J.; ARCHER, H. Geographic Information Systems: A Guide to the Technology. USA, NY, New York: Chapman \& Hall, 1991, 301p. 
BALBIM, R. N. Informação de Trânsito: O Uso de PMVS em Paris. In: CONATRAN Congresso Nacional de Trânsito, V, 2000. Anais... CD ROM. Instituto Nacional de Segurança no Trânsito, 2000.

BRASIL. Lei no 9.503, de 23 de setembro de 1997. Institui o Código de Trânsito Brasileiro. Diário Oficial da União, Brasília, DF, 24 de set. de 1997.

BRENAC,T.; CLABAUX,N. The indirect involvement of buses in traffic accident processes. Safety Science, v. 43, n. 10, p. 835-843, 2005.

CALIJURI,M.L.;RÖHM,S.A. Sistemas de Informações Geográficas. Viçosa. Universidade Federal de Viçosa. Imprensa Universitária, 1994, 34p.

CÂMARA, G.; CASANOVA,M.A.; HEMERLY, A.S.; MAGALHÃES, G.C.; MEDEIROS, C.M.B. Anatomia de Sistemas de Informação Geográfica. In: X Escola de Computação, Campinas, SP, 1996.

CAMPOS, V.B.G; SAMPEDRO, A. Avaliação e Tratamento das Características da InfraEstrutura Viária Urbana que Influenciam a Segurança do Tráfego. Revista Engenharia Civil, Minho, nº 27, 2006.

CARDOSO, G. Utilização de um sistema de informações geográficas visando o gerenciamento da segurança viária no município de São José - SC.1999.134 f. Dissertação (Mestrado em Engenharia Civil)-Centro de Ciências Exatas, Universidade Federal de Santa Catarina, Florianópolis, 1999.

CET - COMPANHIA DE ENGENHARIA DE TRÁFEGO. Curso básico de engenharia de tráfego: Análise de segurança. Prefeitura do Município de São Paulo, Secretaria Municipal de Transportes. 1979. 
CHUEIRE, J. L. G. Segurança viária na cidade de São José do Rio Preto. 2004. 84 f. Dissertação (Mestrado em Transportes) - Escola de Engenharia de São Carlos - Universidade de São Paulo, São Carlos, 2004.

CONGALtON, R.G.; GREEN, K. The ABCs of GIS. An introduction to geographic information systems. Journal of Forestry. Vol. 90(11), November 1992. Disponível em http://cobhomepages.cob.isu.edu/parkerkr/courses/CIS591/Fall07/Readings/Topic\%2001/s8.p df. Acesso em 03 de março de 2006.

CONTRAN - CONSELHO NACIONAL DE TRÂNSITO (2007). Sinalização Vertical de Advertência. Volume II. Brasília, 2007.

DENATRAN - DEPARTAMENTO NACIONAL DE TRÂNSITO. Ministério das Cidades. Instrução Básica de Estatística de Trânsito (RENAEST - Registro Nacional De Acidentes e Estatísticas de Trânsito). Brasília. 2007. Disponível em: http://www.denatran.gov.br/Instrucao\%20Basica\%20de\%20Estatistica\%20de\%20Transito/FR AMES.htm. Acesso em 01 fevereiro 2007.

EMDEC - EMPRESA MUNICIPAL DE DESENVOLVIMENTO DE CAMPINAS. Sumário estatístico de acidentes de trânsito em Campinas 2002-2003. 40 p. Campinas, 2003.

ECMT - EUROPEAN CONFERENCE OF MINISTERS OF TRANSPORT. Safety on Road Traffic for Vulnerable Users. Third Road Safety Week in the UN/ECE Region. Paris, France. European Conference of Ministers of Transport, 2000. 108 p.

ETSC - EUROPEAN TRANSPORT SAFETY COUNCIL. Transport Safety Performance in the EU a Statistical Overview. Brussels,2003.

FERRAZ, A. C. P.; FORTES, F.Q.; SIMÕES, F.A. Apostila de Engenharia de Tráfego Urbano - Fundamentos Práticos. São Carlos: USP - Escola de Engenharia de São Carlos, 123 p, 1999. 
FERRAZ, A. C. P; TORRES, I.G.E. Transporte Público Urbano. Editora RiMa, São Carlos, 2004.

FERRAZ, A. C. P.; RAIA Jr. A. A. Segurança no Trânsito. Edição Preliminar. Apostila de aula. Escola de Engenharia de São Carlos - EESC, Universidade de São Paulo - USP. São Carlos: Departamento de Engenharia de Transportes, 2005.

FHWA - FEDERAL HIGHWAY ADMINISTRATION. Study Tour For Road Safety Audits - Part I. U.S. Departament of Transportation, Washington. D.C, 1997.

GEIPOT - EMPRESA BRASILEIRA DE PLANEJAMENTO DE TRANSPORTE. Boletim de ocorrência : Um instrumento de análise dos acidentes de trânsito. 51 p. Ministério dos Transportes. Brasília, 1999.

GOLD, P. A. Segurança de Trânsito: aplicações de engenharia para reduzir acidentes. EUA: Banco Interamericano de Desenvolvimento,p.1-3, 1998.

HYDÉN, C. The Swedish Traffic Conflict Techniques. Sweden. University of Lund, 1987.

HOFFMAN, M.H.; LEGAL, E.J. Capítulo 19: Sonolência, Estresse, Depressão e Acidentes de Trânsito.In:_____Comportamento Humano no Trânsito. São Paulo. Casa do Psicólogo Livraria e Editora Ltda. 2004. p. 341-358.

HUXHOLD, W. E.; LEVINSOHN, A. G. Managing Geographic Information System Projects. USA, NY, Oxford: Oxford University Press Inc., 1995. 247p.

IPEA/ANTP - INSTITUTO DE PESQUISA ECONÔMICA APLICADA / ASSOCIAÇÃO NACIONAL DOS TRANSPORTES PÚBLICOS. Impactos sociais e econômicos dos acidentes de trânsito nas aglomerações urbanas brasileiras. Relatório Executivo. Instituto de Pesquisa EconômicaAplicada. Agência Nacional de Transportes Terrestres. Brasília, 2003. 
Disponível em http://www.ipea.gov.br/TemasEspeciais/acidentesdetransito/Portugues.pdf. Acesso em 06 de fevereiro de 2006.

IBGE - INSTITUTO BRASILEIRO DE GEOGRAFIA E ESTATÍSTICA. Projeção da população. $\quad$ Brasília, $2008 . \quad$ Disponível em ftp://ftp.ibge.gov.br/Estimativas_Projecoes_Populacao/Estimativas_2006/ . Acesso em 06 de abril de 2006.

KENNEDY, M. The Global Positioning System and GIS: An Introduction. University of Kentucky. USA, Michigan, Chelsea: Ann Arbor Press, 1996. 268p.

MANTOVANI, V. R. Proposta de um sistema integrado de gestão em segurança de tráfego- SIG SET. 2003.155 f. Dissertação (Mestrado em Engenharia Civil)-Centro de Ciências Exatas e de Tecnologia, Universidade Federal de São Carlos, São Carlos, 2003.

MEIRELLES, R.L.M. Aplicação da técnica sueca de análise de conflitos de tráfego em cruzamentos críticos da cidade de São Carlos. 2003. 138 f. Dissertação (Mestrado em Transportes) - Escola de Engenharia de São Carlos - Universidade de São Paulo, São Carlos, 2003.

MINISTÉRIO DOS TRANSPORTES. Procedimentos para o Tratamento de Locais Críticos de Acidentes de Trânsito. Ministério dos Transportes.Brasília,D.F., 2002.

MINISTÉRIO DOS TRANSPORTES. Programa PARE. Ministério dos Transportes.Brasília,D.F., 2003.

MON - MA, M. M. Análise da importância das variáveis intervenientes nos acidentes de trânsito em interseções urbanas utilizando Redes Neurais Artificiais. 2005.140 f. Dissertação (Mestrado em Engenharia Civil)-Centro de Ciências Exatas e de Tecnologia, Universidade Federal de São Carlos, São Carlos, 2005. 
MUHLRAD, N. Technique des Conflits of Traffic. Manual de Utilisateur. Synthese INRETS,1988, nº 11, Arcueli, Fr.: INRETS

NODARI,C.T.; LINDAU, L. A.. Auditoria de Segurança Viária. Revista dos Transportes, v.9, n2, p. 48-66, 2001.

OMS - ORGANIZAÇÃO MUNDIAL DA SAÚDE (2004). Informe mundial sobre prevención de los traumatismos causados por el tránsito: Resumen. Genebra,2004.

PIETRANTÔNIO, H. Manual de procedimento de pesquisa para análise de conflitos de tráfego em interseções. Seção de Engenharia de Tráfego e Transporte de Passageiros - IPT. Publicação $\quad$ Interna. $1991,105 p$ Disponível http://www.poli.usp.br/p/hugo.pietrantonio/Manual91.pdf. Acesso em 12 de fevereiro de 2006.

PORTUGAL, L. S.; GOLDNER, L.G. Estudo de Pólos Geradores de Tráfego e de seus impactos nos sistemas viários e de transportes. São Paulo. Editora Edgard Blücher Ltda, $1^{\text {a }}$ edição, 2003. 322p.

QUEIROZ, M.P. Análise espacial dos acidentes de trânsito do município de Fortaleza. 2003.141 f. Dissertação (Mestrado em Engenharia de Transporte), Universidade Federal do Ceará, Fortaleza, 2003.

RAIA JÚNIOR, A. A; SOUZA, F.R. Análise Espacial dos Acidentes de Trânsito em São Carlos-SP com Uso de Sistemas de Informações Geográficas. In: CONATRAN - Congresso Nacional de Trânsito, V, 2000. Anais... CD ROM. Instituto Nacional de Segurança no Trânsito, 2000.

RAIA JÚNIOR, A. A et al. O uso de SIG para Análise Espacial de Acidentes de Trânsito. In: Congresso e Feira para Usuários de Geoprocessamento, VII, 2001, Curitiba. Anais... CD ROM. Fator GIS Eletrônicos, 2001a. 
RAIA JÚNIOR, A.A. Fundamentos de Segurança no Trânsito. São Carlos: UFSCarl Departamento de Engenharia Civil, Notas de Aula. 131 p. 2004.

RAIA JÚNIOR, A.A. (Coord) Banco de Dados Relacional de Acidentes de Trânsito do Município de São Carlos. DECiv/UFSCar/Prefeitura Municipal de São Carlos. São Carlos. 2004.

RENÚNCIO,L.E. "Integração do cadastro técnico multifinalitario a sistemas de informações geográficas visando implantação de um reservatório para abastecimento de água no município de Cocal do Sul-SC". 1995. 203 f. Dissertação (Mestrado) Universidade Federal de Santa Catarina, Centro Tecnológico, Florianópolis, 1995.

ROZESTRATEN, R. J. A. Psicologia do Trânsito. Conceitos e processos básicos. São Paulo: EPU - Editora Pedagógica e Universitária Ltda e EDUSP -Editora da Universidade de São Paulo, 148p, 1988.

SANCHES, S.P. Planejamento dos Transportes Urbanos. São Carlos: UFSCarl Departamento de Engenharia Civil,2000. 53 p. Notas de Aula.

SANTOS, L. Análise dos acidentes de trânsito do município de São Carlos utilizando Sistema de Informações Geográficas - SIG e ferramentas de estatística espacial. 2006.137 f. Dissertação (Mestrado em Engenharia Urbana)-Centro de Ciências Exatas e de Tecnologia, Universidade Federal de São Carlos, São Carlos, 2006.

SETTI, J.R.A. Identificação e classificação de locais inseguros em vias urbanas. 1985.85 f. Dissertação (Mestrado em Transportes) - Escola de Engenharia de São Carlos - Universidade de São Paulo, São Carlos, 1985.

SETTI, J.R.A. Apostila de Tecnologia dos Transportes. São Carlos: USP - Escola de Engenharia de São Carlos, 276 p, 2003. 
SIMÕES, F.A. SEGTRANS - Sistema de gestão de segurança no trânsito urbano. 2001. 220 f. Tese (Doutorado em Transportes) - Escola de Engenharia de São Carlos Universidade de São Paulo, São Carlos, 2001.

TEIXEIRA, K. M. Segurança viária na cidade de Belém. 2003. 162 f. Dissertação (Mestrado em Transportes) - Escola de Engenharia de São Carlos - Universidade de São Paulo, São Carlos, 2003.

THILL, J. Geographic Information Systems for Transportation in Perspective. Transportation Research Part C. Buffalo, NY, USA, no 8, p. 3-12, 2000.

TOURINHO, L.F.B. Determinação de parâmetros para diagnóstico de segurança de pedestres em interseções urbanas semaforizadas com a análise de conflito de tráfego. 2002. 217 f. Dissertação (Mestrado em Transportes) - Escola Politécnica - Universidade de São Paulo, São Paulo, 2002.

TRANSERP - EMPRESA DE TRÂNSITO E TRANSPORTE URBANO DE RIBEIRÃO PRETO S/A. Estatísticas de acidentes de trânsito. Ribeirão Preto, 2003. Disponível em http://www.coderp.com.br/transerp/i07PRINCIPAL.ASP?Pagina=/transerp/estatistica/2003/i0 7apresenta.htm . Acesso em 04 de fevereiro de 2007.

TRANSPORTATION RESEARCH BOARD - TRB. TRB Special Report \# 250. (1984). Washington,DC, EUA. 1984

VASCONCELlOS, E.A. O que é trânsito? Coleção 162: Primeiros Passos. Editora Brasiliense S. A. São Paulo, 1985. 162p.

VIVIANE, E.; SÓRIA,M.H.A.; SILVA,A.N.R. (1994). Gerenciamento de Vias Não Pavimentadas e a Utilização de Sistemas de Informação Geográfica. In: Congresso Brasileiro de Cadastro Técnico Multifinalitário.1. Florianópolis,1994. Anais. P. 118-126. 
ANEXOS 


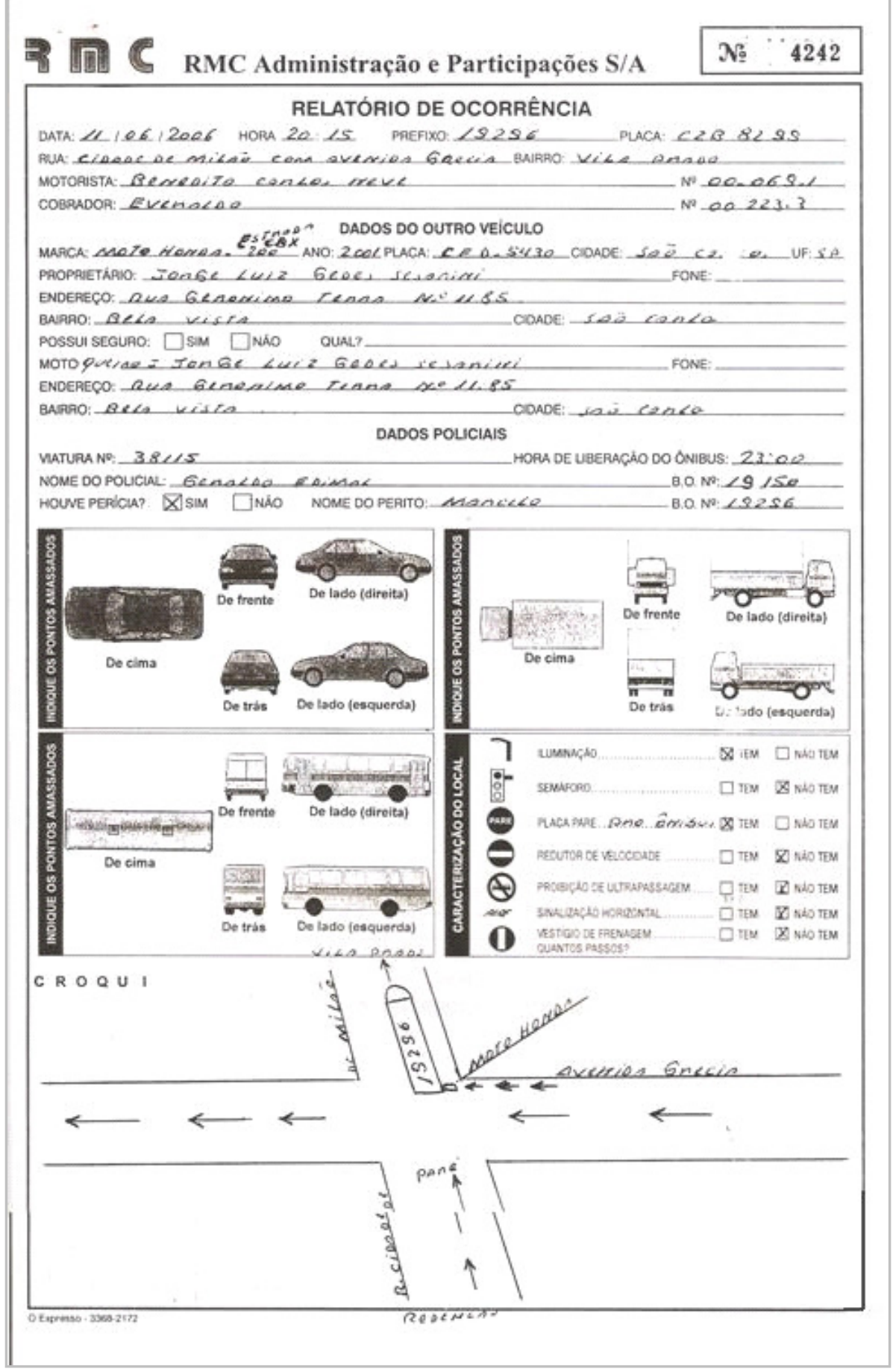

Figura A1: Relatório de Ocorrência de Acidentes de Trânsito (frente) Fonte: Empresa Athenas Paulista 


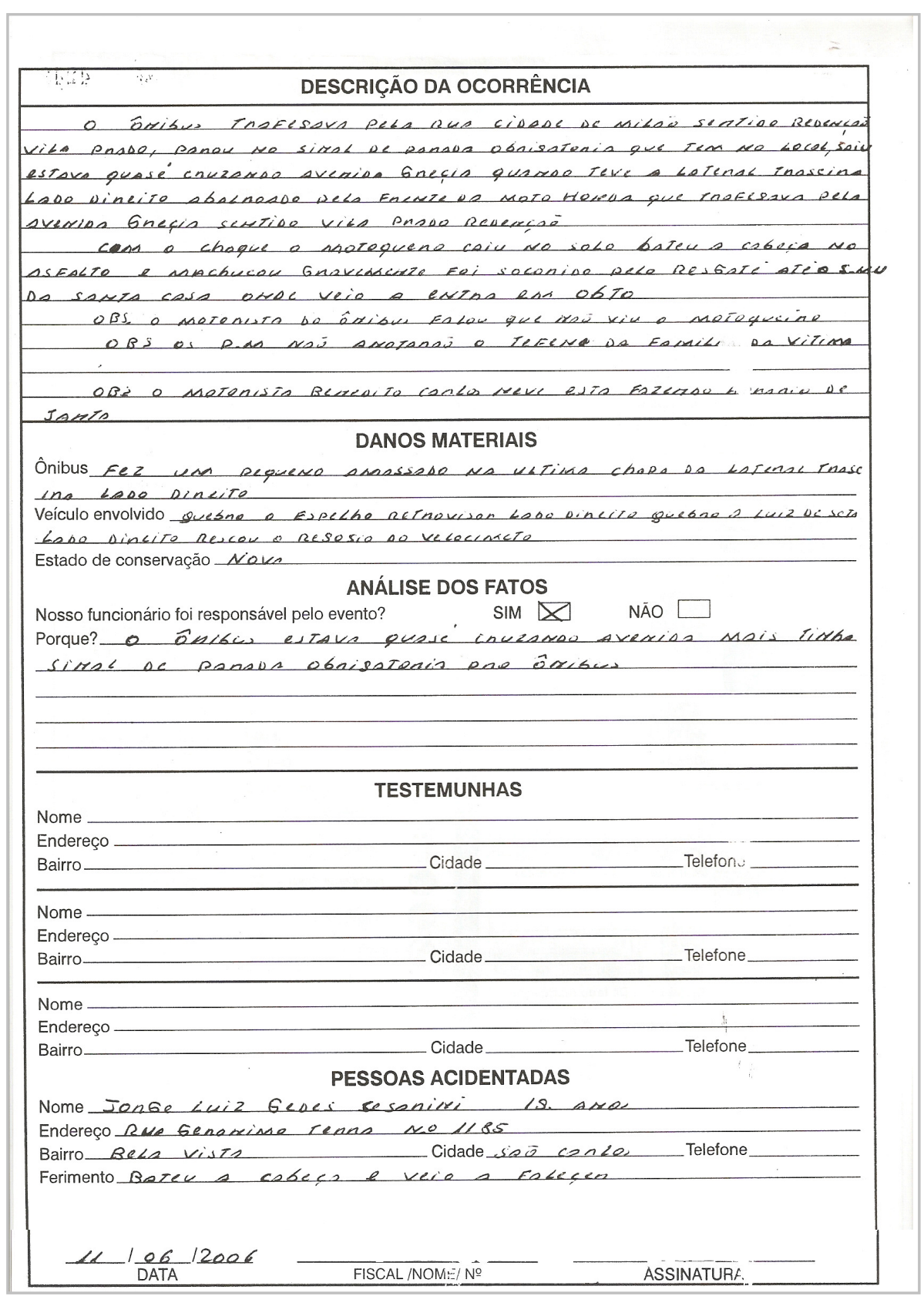

Figura A2: Relatório de Ocorrência de Acidentes de Trânsito (verso) Fonte: Empresa Athenas Paulista 


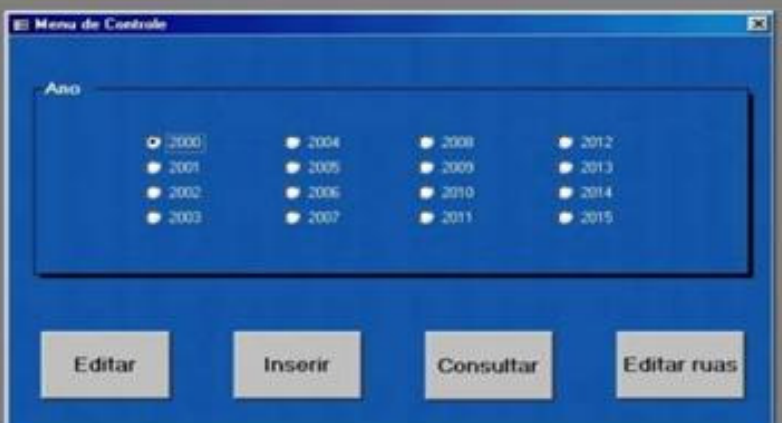

Figura A3: Tela de consulta aos anos no BDAT

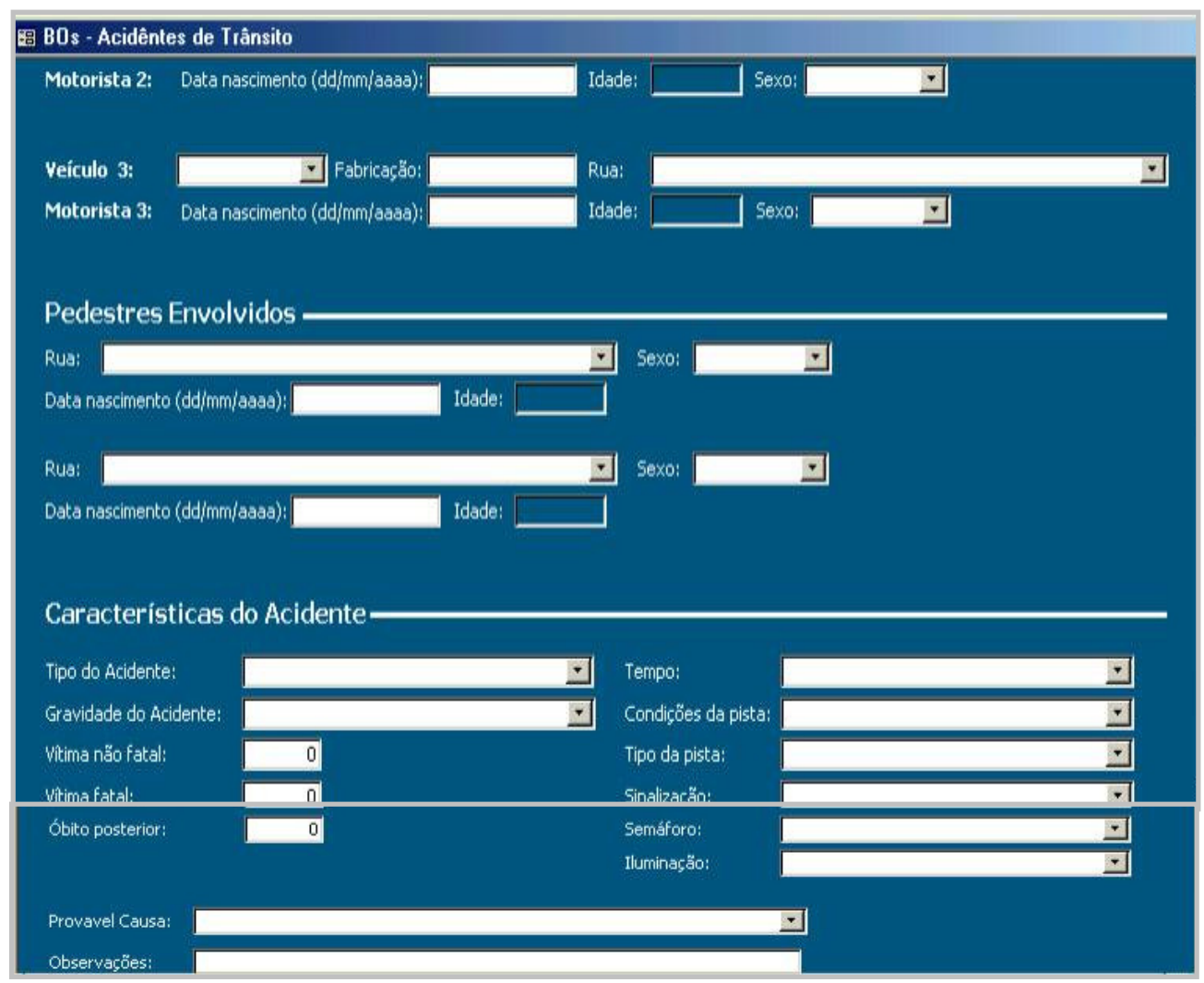

Figura A4: Formulário de preenchimento do BDAT para a inserção dos dados de acidentes de trânsito 


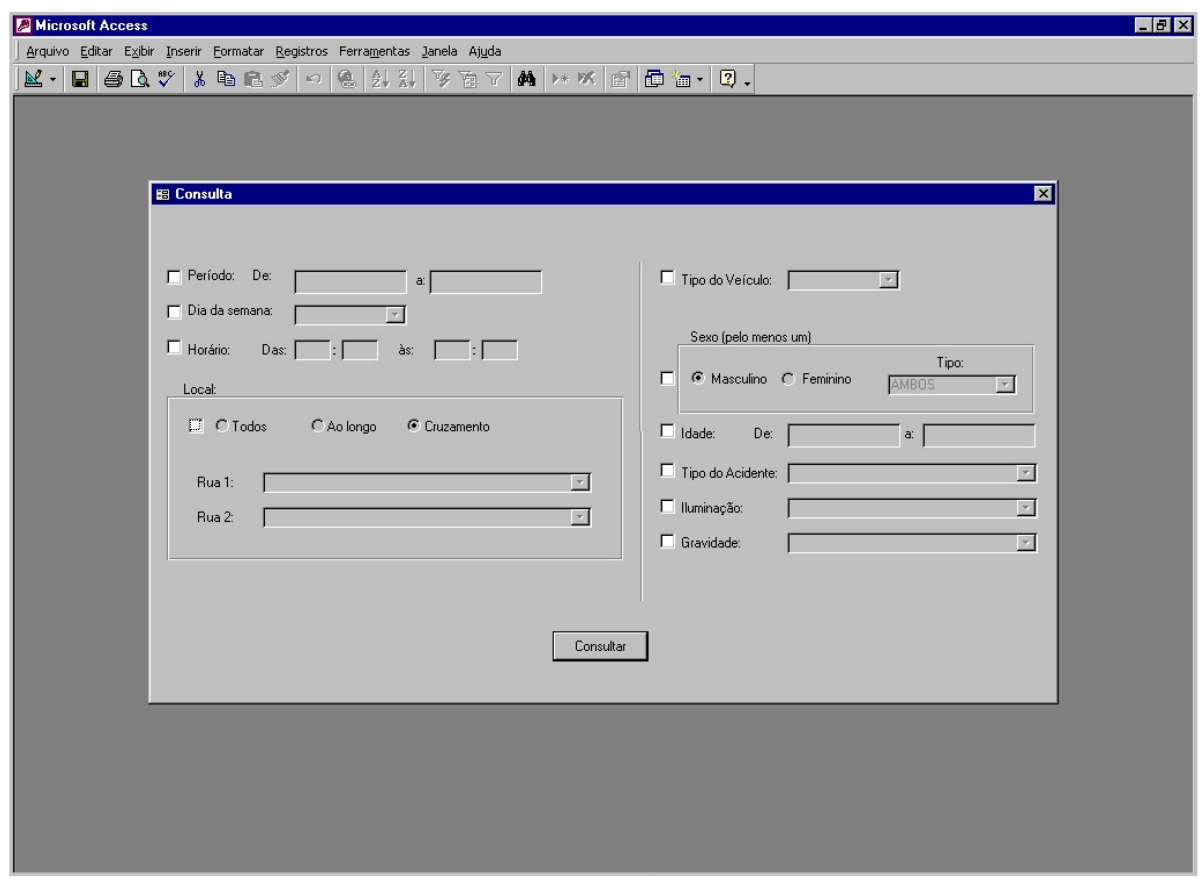

Figura A.5: Tela de consulta às características dos acidentes do BDAT

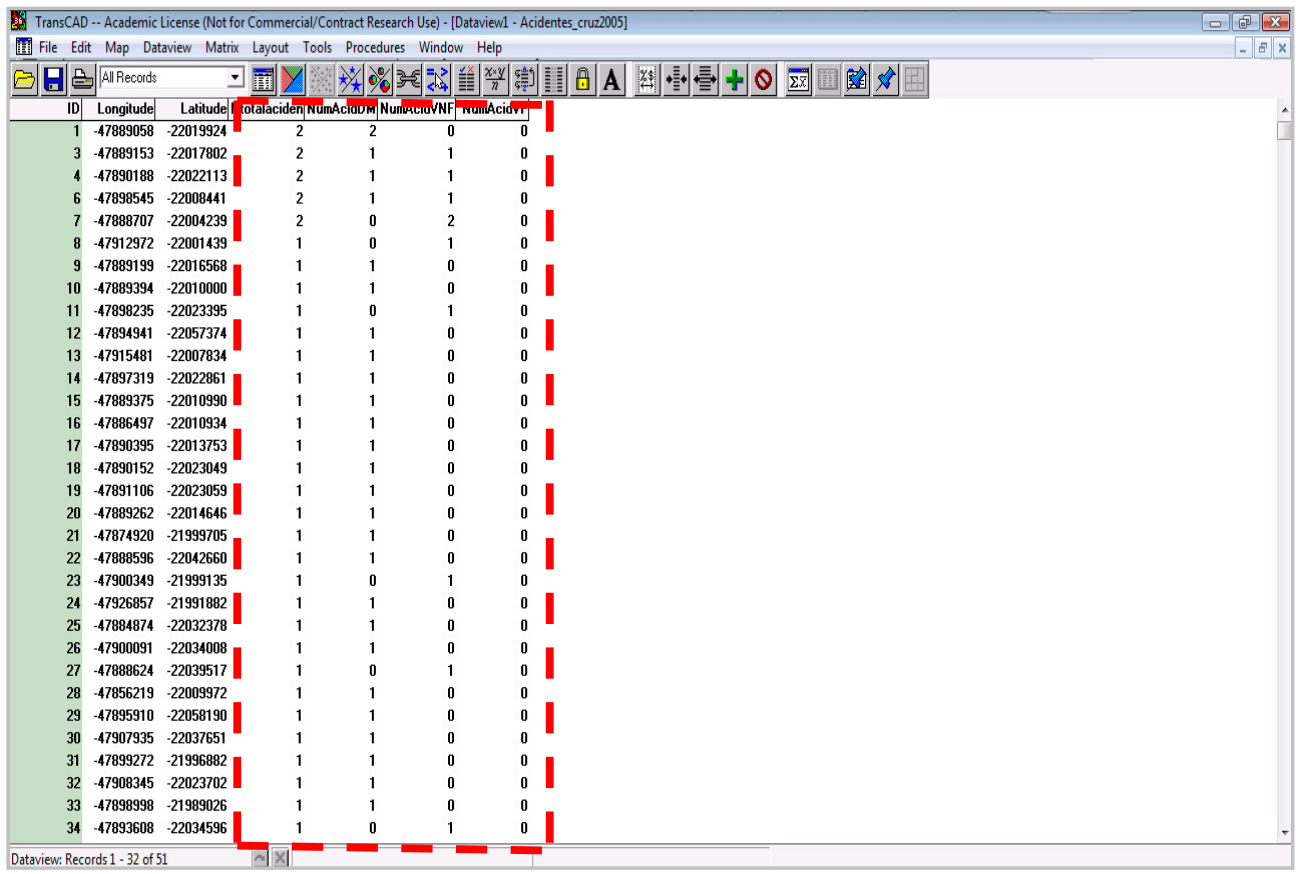

Figura A.6: Banco de atributos gráficos e não gráficos dos acidentes de trânsito para o biênio $2005-2006$ 